\title{
Athens Journal of Architecture
}

Quarterly Academic Periodical,

Volume 7, Issue 4, October 2021

VRL: https://www.athensjournals.gr/aja

Email: journals@atiner.gr

e-ISSN: 2407-9472 DOI: 10.30958/aja

Front Pages

FRANCESCO DEL SOLE

Building on the Border: Architecture as a Meeting Place

PASQUALE CUCCO \& AGUSTIN MARIANO SANTORO

Holistic Approach in Recovery and Conservation of Modern Architecture as Sign of Historical Identity

ULRIKA KARLSSON, CECILIA LUNDBÄCK, DANIEL NORELL, EINAR RODHE \& VERONICA SKEPPE

A Live Interior: Environments, Assemblies, Materialities

RAFFAELLA MADDALUNO

Between Earth and Sky: Art and Architecture in Dialogue in the Work of Rui Chafes and Camilo Rebelo 


\section{Athens Journal of Architecture}

Published by the Athens Institute for Education and Research (ATINER)

\section{$\underline{\text { Editors }}$}

- Dr. Nicholas N. Patricios, Vice President of Strategic Planning \& Analysis, ATINER and Professor \& Dean Emeritus, School of Architecture, University of Miami, USA

\section{Co-Editors}

- Dr. Clara Germana Gonçalves, Head, Architecture Unit, ATINER \& Researcher, CITAD (Centro de Investigação em Território, Arquitectura e Design), Lusíada University and Associate Professor, ISMAT (Instituto Superior Manuel Teixeira Gomes), Portugal.

- Dr. Fatih Rifki, Academic Member, ATINER \& Professor, Montana State University, USA.

- Dr. Jesus J. Lara, Academic Member, ATINER \& Associate Professor, The Ohio State University, USA.

- Dr. Giulia Pellegri, Vice Dean \& Associate Professor, Architecture-Polytechnic School, University of Genoa, Italy.

\section{Editorial \& Reviewers' Board}

https://www.athensjournals.gr/aja/eb

Administration of the Journal

1.Vice President of Publications: Dr Zoe Boutsioli

2.General Managing Editor of all ATINER's Publications: Ms. Afrodete Papanikou

3.ICT Managing Editor of all ATINER's Publications: Mr. Kostas Spyropoulos

4.Managing Editor of this Journal: Ms. Olga Gkounta

ATINER is an Athens-based World Association of Academics and Researchers based in Athens. ATINER is an independent and non-profit Association with a Mission to become a forum where Academics and Researchers from all over the world can meet in Athens, exchange ideas on their research and discuss future developments in their disciplines, as well as engage with professionals from other fields. Athens was chosen because of its long history of academic gatherings, which go back thousands of years to Plato's Academy and Aristotle's Lyceum. Both these historic places are within walking distance from ATINER's downtown offices. Since antiquity, Athens was an open city. In the words of Pericles, Athens"...is open to the world, we never expel a foreigner from learning or seeing". ("Pericles' Funeral Oration", in Thucydides, The History of the Peloponnesian War). It is ATINER's mission to revive the glory of Ancient Athens by inviting the World Academic Community to the city, to learn from each other in an environment of freedom and respect for other people's opinions and beliefs. After all, the free expression of one's opinion formed the basis for the development of democracy, and Athens was its cradle. As it turned out, the Golden Age of Athens was in fact, the Golden Age of the Western Civilization. Education and (Re)searching for the 'truth' are the pillars of any free (democratic) society. This is the reason why Education and Research are the two core words in ATINER's name.

$* * * * * * * * * * * * * * * * * * * * * * * * * * * * * * * * * * * * * * * * * * * * * * * * * * * * * * * * * * * * * * * * * * * * * * * * * * * * * * * * * * * * * * * * * * * * * * *$

The Athens Journal of Architecture (AJA) is an Open Access quarterly double-blind peer reviewed journal and considers papers from all areas of architecture. Many of the papers published in this journal have been presented at the various conferences sponsored by the Architecture Unit of the Athens Institute for Education and Research (ATINER). All papers are subject to ATINER's Publication Ethical Policy and Statement. 
The Athens Journal of Architecture

ISSN NUMBER: 2407-9472- DOI: 10.30958/aja

Volume 7, Issue 4, October 2021

Download the entire issue ( $\underline{\mathrm{PDF}})$

Front Pages

i-viii

Building on the Border: Architecture as a Meeting

Place

Francesco Del Sole

Holistic Approach in Recovery and Conservation of

Modern Architecture as Sign of Historical Identity

Pasquale Cucco \& Agustin Mariano Santoro

A Live Interior: Environments, Assemblies, Materialities

463

Ulrika Karlsson, Cecilia Lundbäck, Daniel Norell,

Einar Rodhe \& Veronica Skeppe

Between Earth and Sky: Art and Architecture in

483

Dialogue in the Work of Rui Chafes and Camilo Rebelo

Raffaella Maddaluno 


\section{Athens Journal of Architecture Editorial and Reviewers' Board}

$\underline{\text { Editor }}$

- Dr. Nicholas N. Patricios, Vice President of Strategic Planning \& Analysis, ATINER and Professor \& Dean Emeritus, School of Architecture, University of Miami, USA.

\section{Co-Editors}

- Dr. Clara Germana Gonçalves, Head, Architecture Unit, ATINER \& Researcher, CITAD (Centro de Investigação em Território, Arquitectura e Design), Lusíada University and Associate Professor, ISMAT (Instituto Superior Manuel Teixeira Gomes), Portugal.

- Dr. Fatih Rifki, Academic Member, ATINER \& Professor, Montana State University, USA.

- Dr. Jesus J. Lara, Academic Member, ATINER \& Associate Professor, The Ohio State University, USA.

- Dr. Giulia Pellegri, Vice Dean \& Associate Professor, Architecture-Polytechnic School, University of Genoa, Italy.

\section{Editorial Board}

- Dr. Arthur Chen, Academic Member, ATINER \& Director, Center for World Heritage Studies, School of Architecture, University of Minnesota, USA.

- $\quad$ Dr. Fatih A. Rifki, Professor, Montana State University, USA.

- Dr. Nico Kotze, Professor, University of Johannesburg, South Africa.

- $\quad$ Dr. Eren Erdener, Professor Emeritus, The University of Oklahoma, USA.

- $\quad$ Dr. William Douglas, Professor \& Associate Dean, College of Art \& Design, Louisiana State University, USA.

- Dr. Angus Shuenn-Ren Liou, Professor \& Vice Dean, College of Planning and Design, National Cheng Kung University, Taiwan.

- Dr. Vimolsiddhi Horayangkura, Professor, Faculty of Architecture and Planning, Thammasat University, Thailand.

- Dr. Stefania Mornati, Professor, Department of Civil Engineering and Computer Science Engineering, University of Rome, Italy.

- Mr. Ryadi Adityavarman, Associate Professor, Kansas State University, USA.

- Dr. David A. Badillo, Associate Professor, City University of New York, USA.

- $\quad$ Dr. Wah Sang Wong, Associate Professor, Department of Architecture, The University of Hong Kong, Hong Kong.

- $\quad$ Dr. Milica Muminovic, Assistant Professor, University of Canberra, Australia.

- $\quad$ Dr. Levent Kara, Assistant Professor, School of Architecture and Community Design, University of South Florida, USA.

- $\quad$ Dr. Nik Nikolov, Assistant Professor, Lehigh University, USA.

- $\quad$ Dr. Zeynep Akture, Assistant Professor, Izmir Institute of Technology -Department of Architecture, Turkey.

- Dr. François Blanciak, Lecturer, Faculty of Architecture, Design and Planning, University of Sydney, Australia.

- $\quad$ Dr. Nick McCullen, Lecturer, Department of Architecture and Civil Engineering, University of Bath, UK.

- Dr. Gehan Selim, Lecturer, School of Architecture, Planning and Civil Engineering, Queens' University Belfast, United Kingdom.

- $\quad$ Dr. Anna Hooper, Tutor/Researcher, Melbourne School of Design, University of Melbourne, Australia.

- Dr. Ana Peric, Lecturer \& Chair of Spatial Development, Institute for Spatial and Landscape Development, ETH Zurich.

- Dr. Kees Doevendans, Researcher, Department of the Built Environment, Technical University of Eindhoven, The Netherlands.

- $\quad$ Dr. Carlos Alberto Tello, Postdoctoral Fellow, University of Montreal, Canada.

- General Managing Editor of all ATINER's Publications: Ms. Afrodete Papanikou

- ICT Managing Editor of all ATINER's Publications: Mr. Kostas Spyropoulos

- Managing Editor of this Journal: Ms. Olga Gkounta (bio)

\section{Reviewers' Board}

Click Here 


\section{President's Message}

All ATINER's publications including its e-journals are open access without any costs (submission, processing, publishing, open access paid by authors, open access paid by readers etc.) and is independent of presentations at any of the many small events (conferences, symposiums, forums, colloquiums, courses, roundtable discussions) organized by ATINER throughout the year and entail significant costs of participating. The intellectual property rights of the submitting papers remain with the author. Before you submit, please make sure your paper meets the basic academic standards, which includes proper English. Some articles will be selected from the numerous papers that have been presented at the various annual international academic conferences organized by the different divisions and units of the Athens Institute for Education and Research. The plethora of papers presented every year will enable the editorial board of each journal to select the best, and in so doing produce a top-quality academic journal. In addition to papers presented, ATINER will encourage the independent submission of papers to be evaluated for publication.

The current issue is the fourth of the seventh volume of the Athens Journal of Architecture (AJA), published by the Architecture Unit of ATINER

Gregory T. Papanikos

President

ATINER 


\section{Athens Institute for Education and Research}

\section{A World Association of Academics and Researchers}

\section{$12^{\text {th }}$ Annual International Conference on Architecture}

4-7 July 2022, Athens, Greece

The Architecture Unit of ATINER, will hold its 12 ${ }^{\text {th }}$ Annual International Conference on Architecture, 4-7 July 2022, Athens, Greece sponsored by the Athens Journal of Architecture. The aim of the conference is to bring together academics and researchers from all areas of Architecture. You may participate as stream organizer, presenter of one paper, chair a session or observer. Please submit a proposal using the form available (https://www.atiner.gr/2022/FORM-ARC.doc).

\section{Academic Member Responsible for the Conference}

- Dr. Nicholas N. Patricios, Vice President of Strategic Planning \& Analysis, ATINER and Professor \& Dean Emeritus, School of Architecture, University of Miami, USA.

- Dr. Clara Germana Gonçalves, Head, Architecture Unit, ATINER \& Researcher, CITAD (Centro de Investigação em Território, Arquitectura e Design), Lusíada University and Associate Professor, ISMAT (Instituto Superior Manuel Teixeira Gomes), Portugal.

- Dr. Fatih Rifki, Academic Member, ATINER \& Professor, Montana State University, USA.

- Dr Anna Hooper, Academic Member, ATINER, Coordinator, Lecturer, Lead Tutor, Ormond College and Melbourne School of Design, The University of Melbourne, Australia.

- Dr. Maria João Dos Reis Moreira Soares, Academic Member, ATINER \& Associate Professor, Lusiada University Lisbon, and Research Fellow, CITAD - Research Centre on Territory, Architecture \& Design, Portugal.

- Abstract Submission: 6 December 2021

\section{Important Dates}

- Acceptance of Abstract: 4 Weeks after Submission

- Submission of Paper: 6 June 2022

\section{Social and Educational Program}

The Social Program Emphasizes the Educational Aspect of the Academic Meetings of Atiner.

- Greek Night Entertainment (This is the official dinner of the conference)

- Athens Sightseeing: Old and New-An Educational Urban Walk

- Social Dinner

- Mycenae Visit

- Exploration of the Aegean Islands

- Delphi Visit

- Ancient Corinth and Cape Sounion

More information can be found here: https://www.atiner.gr/social-program

\section{Conference Fees}

Conference fees vary from $400 €$ to $2000 €$

Details can be found at: https://www.atiner.gr/fees 


\section{Athens Institute for Education and Research}

\section{A World Association of Academics and Researchers}

\section{$12^{\text {th }}$ Annual International Conference on Urban Studies \& Planning, 30-31 May \& 1-2 June 2022, Athens, Greece}

The Architecture Unit in collaboration with the Social Sciences Division of the ATINER will organize its $12^{\text {th }}$ Annual International Conference on Urban Studies \& Planning, 30-31 May \& 1-2 June 2022, Athens, Greece sponsored by the Athens Journal of Architecture. The aim of the conference is to bring together academics and researchers from all areas of social sciences such as urban sociology, urban geography, urban design, urban planning, architecture, etc. You may participate as stream leader, presenter of one paper, chair of a session or observer. Please submit a proposal using the form available (https:// www.atiner.gr/2022/FORM-PLA.doc).

\section{Important Dates}

- Abstract Submission: 1 November 2021

- Acceptance of Abstract: 4 Weeks after Submission

- Submission of Paper: 2 May 20221

\section{Academic Members Responsible for the Conference}

- Dr. Nicholas N. Patricios, Vice President of Strategic Planning \& Analysis, ATINER and Professor \& Dean Emeritus, School of Architecture, University of Miami, USA.

- Dr. Virginia Sisiopiku, Head, Transportation Engineering Unit, ATINER, \& Associate Professor, The University of Alabama at Birmingham, USA.

- Dr. Jesus J. Lara, Academic Member, ATINER \& Associate Professor, The Ohio State University, USA.

- Dr. Giulia Pellegri, Associate Professor, Architecture-Polytechnic School, University of Genoa, Italy.

\section{Social and Educational Program}

The Social Program Emphasizes the Educational Aspect of the Academic Meetings of Atiner.

- Greek Night Entertainment (This is the official dinner of the conference)

- Athens Sightseeing: Old and New-An Educational Urban Walk

- Social Dinner

- Mycenae Visit

- Exploration of the Aegean Islands

- Delphi Visit

- Ancient Corinth and Cape Sounion

More information can be found here: https://www.atiner.gr/social-program

\section{Conference Fees}

Conference fees vary from $400 €$ to $2000 €$

Details can be found at: https://www.atiner.gr/fees 


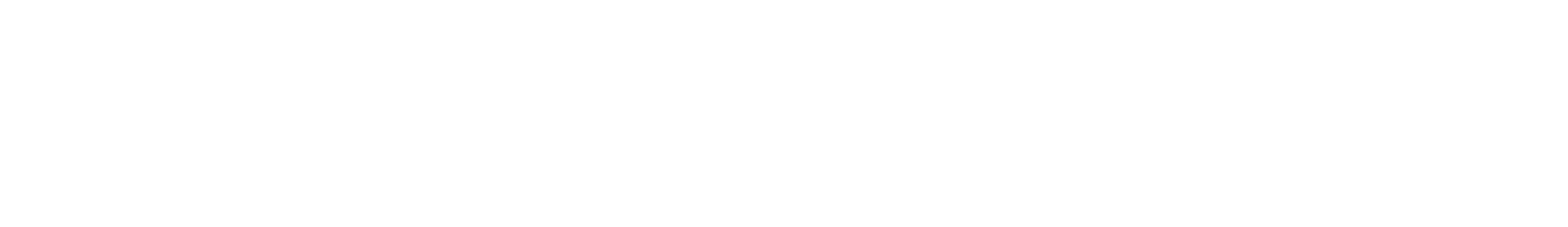




\title{
Building on the Border: Architecture as a Meeting Place
}

\author{
By Francesco Del Sole*
}

\begin{abstract}
To establish a border signifies defining a fixed point from which to start and to which to refer in order to circumscribe controlled and measured environments. It is not important whether it is a border between states and regions or private and public spaces, because the main effect of the border is to sanction a diversity. This proposal will analyse three case-studies that, starting from antiquity to the contemporary age, have proposed over time different ways of conceiving the border, making architecture the convergence point. The first is the Temple of Diana at Ephesus, a monument created by Greek artists located in Persian territory. It stood on the peninsula of Anatolia, the border land par excellence in the Hellenistic world, a place where the dominant Western cultures of Greece and Persia clashed. The second is Castel Velturno, a border utopia belonging to Prince-Bishop Cristoforo Madruzzo, who deposited his dreams of unification between the North and the South of Christianity which were torn apart by the theological demands addressed during the Council of Trento. Finally, this proposal will examine the contemporary project entitled the Bi-National Community Skyscraper, which proposes a reinterpretation of the walls erected on the border between the USA and Mexico by building a skyscraper on it in which the two communities can meet and merge together.
\end{abstract}

\section{Introduction}

A border is identified as that sign which, by delimiting a territory, divides two places. The act which underlies the meaning of this term is of a man, who has different cultural attitudes and has defined different characteristics and forms of the border over time, taking possession of the territory. ${ }^{1}$

In addition to identifying the border only as a material sign, it is necessary to widen the scope of its meaning to areas that are not purely architectural in order to understand the complexity of this concept. This also takes on a more abstract sense of term and limit: "borders die and rise again, they move, they are erased and reappear unexpectedly. They mark the experience, the language, the space of living, the body with its health and illnesses, the psyche with its divisions and rearrangements, politics with its often absurd cartography, the ego with the plurality of its fragments and their laborious recompositions, society with its divisions, the economy with its invasions and retreats, thought with its maps of order."

\footnotetext{
*Assistant Professor, Department of Cultural Heritage, University of Salento, Italy.

1. On the subject of the border, within the border studies, see above all P. Zanini, Significati del Confine. I Limiti Naturali, Storici, Mentali (Milano: Mondadori, 1997); M. Augè, Tra i Confini. Città, Luoghi, Integrazioni (Milan: Mondadori, 2007); B. Albrecht and L. Benevolo, I Confini del Paesaggio Umano (Rome-Bari: Laterza, 1994); A. C. Varzi, "Teoria e Pratica dei Confini," Sistemi Intelligenti 17, no. 3 (2005): 399-418; G. Paba (Ed.) La Città e il Limite. I Confini della Città (Florence: La Casa Usher, 1990).

2. C. Magris, “Come i Pesci il Mare,” Frontiere - Nuovi Argomenti 38 (1991), 12.
} 
It is necessary to highlight the distinction between border and frontier. The border indicates a common boundary, a way of establishing one's right in a disputed area; the frontier, on the other hand, is the ultimate limit beyond which to venture, it is directed against something or someone. Beyond it you become a foreigner and a different person.

The natural border has always been considered the best line to define the limits of a state and to guarantee its defence, since it follows the homogeneous geographical characteristics of a territory. In history, however, borders have often been drawn using straight lines on maps. In this regard, the boundary is a simple abstract sign that testifies the taking of possession of a territory and sanctions its ownership, modifying and superimposing itself on the physical state of the place. The first boundaries of man on Earth have been largely erased, because they were unstable and unfixed borders that came about from a unified vision of the unlimited natural landscape with which man maintained a certain confidence. ${ }^{3}$ With the formation of cities, the conceptual meaning of boundaries, together with the ways and forms of delimitation, became more complex: the main need was then to establish discontinuity between the natural exterior and the built and regulated urban interior. ${ }^{4}$ In the city, the rules of city living are established and the realization of the urban space, artificial and complex, defines the modalities of the relationships between the people who live there: "The city, within its walls, is culture, the seat of values. Outside it [...] there is the non-civility, the countryside, and the anti-city, the desert-forest." $"$ The urban border, on the one hand, configures the city as an autonomous element with a strong formal identity to which the citizen feels they belong; on the other, because of the fear of external invasions, it takes on a defensive and military character. Over time, the military character of the border has become a sign of the city's control and domination over the countryside: "military borders [...] become networks of fortresses, rationally spaced out and surrounded by empty spaces. Some of them take the form of cities entirely subordinate to the warlike function, i.e., purposely located and conformed."

\section{The New Invisible Boundaries: The Social Boundary}

"Today's great metropolis is crossed by a myriad of boundary lines, barely recognisable, due to uncertain and changing signs, only by the exercised eye of the new metropolitan traveller. These invisible borders trace a strange and sometimes dangerous geography, cutting through streets, neighbourhoods, crossroads in an apparently senseless way. They also divide the inhabitants of the day from the inhabitants of the night. They delimit territories of hunting and robbery and places

3. The Avebury Circle, in Wiltshire, is an example of a boundary marked by man in the Neolithic period, which does not become a world in its own right as opposed to the landscape, but tries to integrate with it. The boundary is a large circle of 450 meters in diameter, made up of stones flanked by a moat, whose excavated material, brought back to the outside, forms the embankment. The boundary marks the passage to a sacred area with the sky as its ceiling.

4. See J. Rykwert and G. Scattone, L'idea di Città. Antropologia della Forma Urbana nel Mondo Antico (Turin: Einaudi, 1981).

5. Albrecht and Benevolo, I Confini del Paesaggio Umano, 1994, 9.

6. F. Rella, Metamorfosi: Immagini del Pensiero (Milan: Feltrinelli, 1984), 71. 
of respite and peace, where hunters and prey eventually rest restlessly, waiting for a new escape and a new pursuit." "This margin of the border between two worlds also exists because of the invisible lines that create social divisions within the city. ${ }^{8}$ The border, in this case, is a symbol of inclusion or exclusion from a community. Social boundaries have always been raised by man; by gathering together in groups accumulated by customs and habits, he has created communal lines through behaviours and principles, which lead the community back to a welldefined and opposing identity. "We think of castes, ethnicities, [...] nations, classes, parties, factions, quarters." Usually, these are social boundaries that do not necessarily need a territorial projection, even though there can often be a correspondence. In this case, the border, although not marked by a physical object, is where there is a gap or an incoherence between the two different parts that divides people: "I don't understand you, you are really strange and belonging to another world. I can even try to drag you into mine by force, but that doesn't change the fact that you are different and elsewhere." definition and perception of borders have conveyed a multidisciplinary scientific interest from which border studies was born. ${ }^{11}$ The historical processes of building material boundaries are intertwined with the identification of identities and affiliations of social communities and together, they constitute an important reference for the search of the contemporary border. Establishing a border, therefore, means founding a space by defining a fixed point from which to start and to which to refer. Marked in this way, the borders circumscribe controlled, measured and recognisable environments. The boundary line can be physical or imaginary, defined by architectural elements or by invisible lines drawn on maps. It has an interscalar character; it is not important that it is a border between states, regions, or private and public spaces, because the sensation you feel when you cross a border is always that of a change. This is due to the difference in the appearance of the two places due to different rules, uses and customs that characterise each. The complete idea of a border, given by the interpenetration between physical and social margins, fulfils a fundamental task: to indicate the place of a difference, real or presumed. As La Cecla says, "[the border is] the space in which cultures explain and confront each other, discovering different ones. The misunderstanding is the border that takes shape." 12

Through the analysis of three case-studies, starting from antiquity to the contemporary age, an attempt will be made to highlight the power that architecture

7. Ibid, 69.

8. On the social and anthropological subject of the border it is useful to consult the studies of Franco la Cecla. In particular see F. La Cecla, Il Malinteso: Antropologia dell'Incontro (Rome-Bari: Laterza, 2003); La Cecla, Mente Locale, per un'Antropologia dell 'Abitare (Milan: Eleuthera, 1993).

9. U. Fabietti, "La Costruzione dei Confini in Antropologia. Pratiche e Rappresentazioni," in Confini: Costruzioni, Attraversamenti, Rappresentazioni (Soveria Mannelli: Rubbettino, 2005), 177.

10. La Cecla, Il Malinteso: Antropologia dell'Incontro, 2003, 167.

11. S. Salvatici, (Eds.) Confini: Costruzioni, Attraversamenti, Rappresentazioni. (Soveria Mannelli: Rubbettino, 2005), 7. The book, which collects the contributions presented at the conference entitled "Confini" (Bolzano, 2004), is useful for an in-depth examination of the topic of borders in an interdisciplinary context.

12. La Cecla, Il Malinteso: Antropologia dell'Incontro, 2003, 162. 
has had throughout history to show all the ways in which the border can be experienced and have proposed different ways of conceiving the border, making architecture the meeting place. This is achieved through an idea implemented several times in the past that could allow us to understand, even today, that "there is a mutual advantage in recognizing the values of both sides." 13

\section{The Temple of Artemis at Ephesus}

The Temple of Diana at Ephesus is a monument created by Greek artists in Persian territory. It was located on the peninsula of Anatolia, the border land par excellence of the Hellenistic world, a place where the dominant western cultures of Greece and Persia clashed. The main reason why it was included in the famous canon of the seven wonders of the ancient world is its intercultural character.

The canon of the Wonders of the World was drawn up in the Hellenistic age, when Alexander the Great's empire was slowly crumbling. ${ }^{14}$ At the time of the death of the Macedonian sovereign in 323 B.C., the peoples of the Mediterranean and the Near East were faced with infighting between all the Dyads. This was the main pivot of contemporary history which gave rise to a single certainty that historians uphold: the age of prosperity and greatness of the Hellenic world had come to a drastic end. In other words, we had passed from a time when Greece and its models had constituted a common denominator for the whole world to a period of slow decay until the fall of the greater world sense of greed. It is precisely this important historical passage that pushed the intellectuals of the $3^{\text {rd }}$ century B.C. to draw up a testament to indicate where man was able to go in the "ancient" epochs by highlighting the results he had achieved. Thus, the canon of the Wonders of the World was born. The common thread which underlies the choice of the seven Mirabilia is the character of universality. Seeing the disastrous results of the fragmentary nature that Alexander had bequeathed, it was decided that those architectural works that were the symbol of eras in which the world proposed universal models of integration between peoples were to be remembered and

13. A. Angelillo and C. Menato, Città di Confine. Conversazioni sul Futuro di Gorizia e Nova Gorica (Portogruaro: Ediciclo, 1994), 16. To fully understand the importance of border architecture, it is useful to consult the extensive studies on the relationship between architecture, local identities and globalisation. In particular see A. Giddens, Modernity and Self-Identity (London: Polity Press, 1991); F. Remotti, Contro l'Identità (Bari: Laterza, 1996); L. Gallino, Globalizzazione e Disuguaglianze (Bari: Laterza, 2001); P. Herle and E. Wegerhoff, Architecture and Identity (Berlin: Lit Verlag, 2009); A. Magnaghi, Il Progetto Locale. Verso la Coscienza di Luogo (Turin: Bollati Berlinghieri, 2010); V. B. Canizaro, Architectural Regionalism: Collected Writings on Place, Identity, Modernity and Tradition (New York: Princeton Architectural Press, 2012).

14. On the theme of the Wonders of the World see M. Fagiolo, "Le Meraviglie e il Meraviglioso," Psicon. Rivista Internazionale di Architettura, 7, no. III (1976): 3-9; M. L. Madonna, "Septem Mundi Miracula come Templi della Virtù," Psicon. Rivista Internazionale di Architettura 7, no. III (1976): 25-31; P. A. Clayton and M. J. Price, Seven Wonders of the World (Turin: Einaudi, 1989); F. Del Sole, Viaggio nella Meraviglia: Descrivere, Immaginare, RiCostruire (Galatina: Congedo, 2019); Del Sole, The Gift of the Spoken Word: The Word-Image Relationship in the Memory Process, in New Approaches in Contemporary Architecture and Urbanism (ed.) H. A. Nia. Cinius Yayınları: Alanya, 2020, 106-114. 
handed down as a model of prosperity for future generations. It is emblematic that all the ancient sources on the subject do not speak of the Wonders of one civilization or another; they speak of the Wonders of the World, making this historical operation one of the first examples of interculturality in which the protagonist is man who is featured alongside his history. If the first two wonders represent the two phases of man's most ancient history (Egypt and Babylon), the other four represent the most recent stages of Mediterranean history. Strongly symbolic, among the others, is the choice to include, among the seven Spectacula, the Temple of Artemis at Ephesus. Located on the peninsula of Anatolia on the border between Greece and Persia, together with the Mausoleum of Halicarnassus, this building represents to historians the phase of coexistence and opposition between two great populations that dominated the Mediterranean: the Persians and the Greeks. ${ }^{15}$ What is important to highlight in these two structures is the confluence of the Persian-Eastern scheme with the Greek one (and vice versa). In the canon of the Wonders, the second age of the world, after the EgyptianBabylonian one, is the coexistence of the two great cultures of Greece and Persia. The construction of the Temple dedicated to Artemis began in the 6th century B.C., at a time when the Greek cities of Asia Minor had fallen under the dominion of Creso, the King of Lydia. Its construction was very long, requiring the contribution of several generations and continuing, therefore, even after Lydia was annexed by Cyrus to the Persian Empire. ${ }^{16}$ All of the Greek spirit of the time was channelled into this majestic work, which was enriched by characters and elements from the culture of the Near East ${ }^{17}$ (Figure 1).

15. On the Temple of Diana at Ephesus, in addition to the ancient sources, reference is made to: E. Falkener, Ephesus, and the Temple of Diana (London, Polity Press, 1862); P. A. Clayton and M. J. Price, Seven Wonders of the World (Turin: Einaudi, 1989), 75-94; A. Bammer, "A Peripteros of the Geometric Period in the Artemision of Ephesus," Anatolian Studies 40 (1990): 137-160; L. R. LiDonnici, "The Images of Artemis Ephesia and Greco-Roman Worship: A Reconsideration," Harvard Theological Review 85, no. 4 (1992): 389-415; G. Rocco, "Guida alla Lettura degli Ordini Architettonici Antichi. II. Lo Ionico," in Guide di Ricerca Storica e Restauro 4, 75-82. Naples: Liguori Editore, 2003; C. Bozzoni, V. Franchetti Pardo, G. Ortolani and A. Viscogliosi, L'architettura del Mondo Antico (Bari: Laterza, 2006).

16. The most important and oldest building (called " $\mathrm{D}$ " by the archaeologists) was built by order of Creso around the middle of the 7th century; we have as evidence of this some inscriptions in Greek and Lidi characters that were on the columns of the temple. It was destroyed on 21 st July 356 B.C. by a certain Erostatus, who set it on fire thinking in this way to make its name immortal.

17. "It is enough to look at the reconstruction of the temple to understand its oriental influences. It is believed that in the 7th century the sanctuary consisted of a structure similar to an altar and two other monuments: the Hekatompedon (so called because it measured 100 feet) and the ramp altar. All this was covered with the construction of the temple "D" and the altar courtyard. The temple "D" had eight columns on the facade and nine on the back, it was not supposed to be a hypetro, although some scholars claim that it was open to the rain, because in the area of the cell was found a pipe that was used to eliminate water. Later it was thought that the roof was truncated and limited to the colonnade, i.e. the central part was uncovered. Access to the high terrace of the sanctuary was by means of marble steps built around the building like a gigantic frame. The high base was 7.85 meters wide and 131 meters long. Pliny tells us that the columns were 20 meters high, slender and elegantly grooved (Ionic style), beautiful capitals supported the beams so big that a legend was born about an intervention of the same goddess to help the architect to erect them; in fact, discouraged by the difficulty of the undertaking, he was contemplating suicide. The frieze had no figures but only a large indentation on the highest selvedge supporting the tympanum. The 

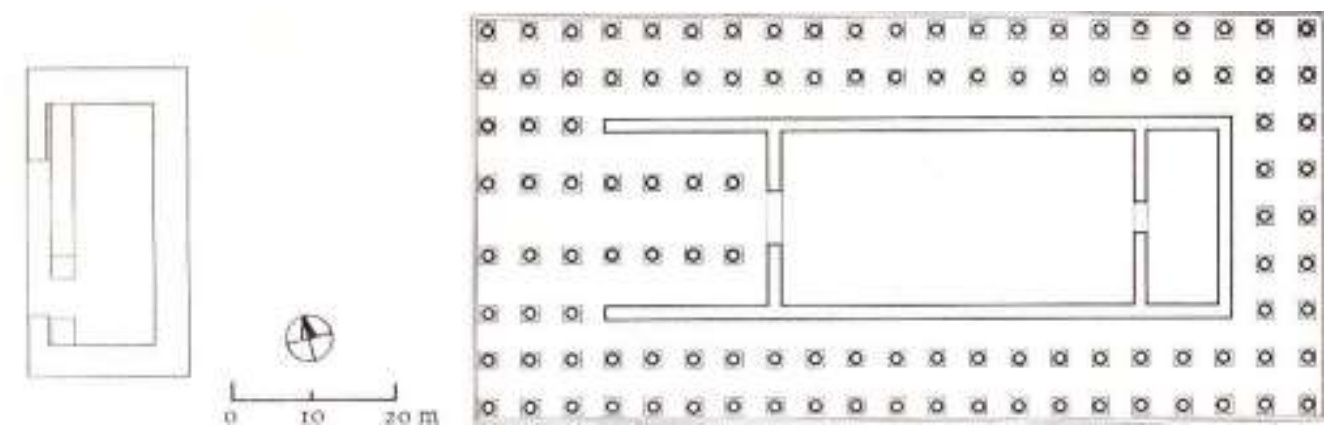

Figure 1. Plan of the Late Classical Temple of Artemis in Ephesus and the Courtyard with the Altar according to the Description of Pliny the Elder Source: Clayton and Price 1989, 77.

Following the sources, it also seems that many of the great names of classical Greek art $\left(5^{\text {th }}\right.$ and $4^{\text {th }}$ centuries B.C.) alternated in this site: Phidias, Polyclitus, Cresila, Fradmon and, finally, Prassitele. ${ }^{18}$ This $5^{\text {th }}$ century B.C. sculpture competition was unique because the artists "were invited to exhibit [the sculptures] in public, and the four most beautiful were then chosen to decorate Temple D.",19 In one of his passages, Gibbon (1780) highlights the popular idea that led Artemision to be considered a Wonder was the fact that it was a "meeting point" between different and hostile civilizations that cooperated in the name of the goddess. ${ }^{20}$ Thus, Artemision generates that "wonder" which contributes to exalt its

tympanum had three openings or windows: the central one had doors and two statues of Amazons stood next to it. Pliny speaks of 127 columns in the complex. The cell was located exactly in the centre of the building. The strange statue with many breasts of Artemis Ephesia represents a mother goddess. The statue is rigid, the lower part resembles the sarcophagus of an Egyptian mummy. If Pliny makes it perfectly clear that the structure is one of the greatest examples of Greek architecture, there are many oriental elements: the sacrificial altar, placed in the cell at a certain distance from the temple façade, was in an asymmetrical position. This arrangement is linked to the Near East, where the temples sometimes had a side entrance and not on the forehead; there were many decorative elements: deer, lions, griffins, sphinxes, sirens and bees; appearance of Artemis' dramatis personae: three openings were made in the tympanum and the goddess often appeared (in the central opening), as if she were appearing, so that her worshippers could see her". Clayton and Price, Seven Wonders of the World, 1989, 75 ss.

18. "Among the most illustrious bronze artists there was a competition despite the differences in age; since they had sculpted Amazons, when they dedicated them in the Temple of Diana at Ephesus, it was decided to choose the most beautiful one according to the opinion of the artists themselves [...] The victory went to Polyclitus, the second to Phidias, the third to Cresila, the fourth to Cidon, the fifth to Fradmon" [Pliny the Elder, Naturalis Historia (Pisa: Giardini, 1985), XVI, 213-215]; "When the Temple was finished, most of the statues were provided with other honours for the artists, but the altar was almost entirely supplied with works by Prassitele. [...] They kept eunuchs as priests, and always looked for them from outside, people who were worthy of such distinction" [Strabo, Geography (Milan: Rizzoli, 1993), XIV]. On this theme see M. Barbanera, "Favole Antiche e Mitologie Moderne. Le Competizioni Artistiche nella Storia dell'arte Greca," Atene e Roma. Rassegna dell'Associazione Italiana di Cultura Classica VIII, no. 1-2 (2014): 7-31. The reference to the Ephesian temple is on page 20.

19. Clayton and Price, Seven Wonders of the World, 1989, 81.

20. "Greek arts and Asian wealth had cooperated in the construction of this sacred and splendid structure. [...] the empires that followed, those of Persia, Macedonia and Rome, venerated its holiness and enriched its splendour". From a passage by E. Gibbon of 1780 cit. in Clayton and Price, Seven Wonders of the World, 1989, 75. 
sacred value. The structure is a complex and unified system of cultural crossroads. It is bizarre to note that, according to Pliny the Elder, the magnificence of Greek architecture is fully expressed in this border work on Persian territory ${ }^{21}$ (Figure 2). $\mathrm{He}$ further states that it was in Ephesus that the fundamental characteristics of Greek architecture exhibited by Vitruvius (the use of the capital and the careful system of proportions between the various architectural elements) first appeared, synthesising the greatness of Artemision with the words Graecae magnificae, the first example in the Hellenic world of a structure that seems to be a "forest of columns".

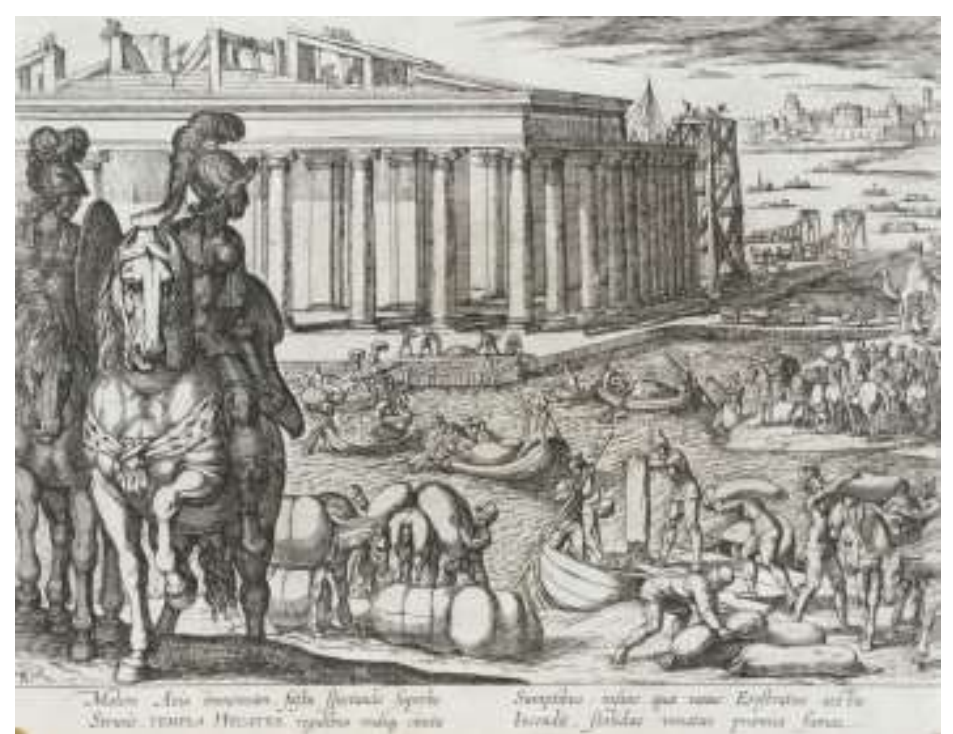

Figure 2. A. Tempesta, The Temple of Artemis at Ephesus (from Septem Orbis Admiranda), 1608

Source: The British Museum - Images Collection - London.

\section{Cristoforo Madruzzo and Castel Velturno}

At the beginning of the $16^{\text {th }}$ century, the European continent raised new and powerful borders. The Protestant reform had a very strong impact on the geography of Europe, becoming the main factor of a cultural identity to be embraced or rejected. Castel Velturno is the materialization of the border as a space of pacification. It is a utopia built on the borders of the Christian world (Trento) belonging to Prince-Bishop Cristoforo Madruzzo, who deposited in this palace his dreams of pacification between the North and the South of Christianity, torn by the theological needs faced during the Council of Trent. The Protestant Reformation brought not only a profound reflection on Catholic doctrine but a real

21. "A realization of Greek grandeur worthy of true wonder is the temple of Diana which still exists in Ephesus. Its construction took 120 years and the contribution of the whole of Asia. [...] It was in the first temple of Diana at Ephesus that for the first time bulls were placed under the columns and capitals were added, and it was decided that the base diameter of the columns should be one eighth of their height" (Pliny the Elder, Naturalis Historia, 1985, XVI, 213-215). 
upheaval of the territorial balances that had been established until then. The Church of Rome seemed to lose its role as the dominant cultural centre, in favour of a Protestant North which was becoming increasingly popular. Therefore, the choosing of the city of Trento as the seat to welcome the Council is emblematic. ${ }^{22}$ Trento was chosen, also thanks to the interest of Charles V, as a border city placed within the limits of the Empire but, at the same time, linked to the politics of the Holy See. It was, thus, capable of expressing the will of the Church of Rome in the first years of the Council to propose a dialogue regarding the ideological demands of German principles.

\section{Cristoforo Madruzzo, Mediator between the Roman Church and the German Princes}

At the time, Trento was ruled by a prince-bishop, Cristoforo Madruzzo, who combined his religious role with his temporal power over the territory. ${ }^{23}$ It was a result of the network of knowledge and relationships of such a personality that the territory of Trento became, in the years of the Council, a real crossroads. His politics perfectly represented the delicate situation of a border land as a "border" which is not only geographical but also ideological and cultural. For this reason, he often insisted that his small frontier territory be assigned a role as a mediator between the defence of Roman orthodoxy and the demands for religious freedom that penetrated the conscience of German princes. The prelate personally lived through all the contrasting events of the Council and, in many ways, tried to influence its outcome. It cannot be denied that, in the course of the Council events, Christopher encountered firm opposition from many prelates. Certainly, one of the factors that annoyed the most conservative souls was the bilingual culture of the bishop. It is obvious that Madruzzo's personality, formed on the border between Italy and the Empire, was influenced by the two cultures in which he grew up: a German one, on his mother's side, and an Italian one, given his cultural formation, which was typically humanistic. It was precisely the nature of his origins that was the main source of his opponents' slander, who even went so far as to accuse him of having supported the Germans from the beginning until he became their leader. Two of Madruzzo's convictions in particular that caused a stir among the ecclesiastics were: his interventions on the themes of justification by faith alone and the need for the Bible to be translated into the vulgar language. ${ }^{24}$ Madruzzo's

22. See in particular S. Cavallotto, "Luterani e Cattolici, Storia di un Dialogo Mancato e Ritrovato," Syzetesis V/2 (2018): 227-250; A. Prosperi, L'Eresia del Libro Grande. Storia di Giorgio Siculo e Della sua Setta (Milan: Feltrinelli, 2000).

23. On Cristoforo Madruzzo see C. De Giuliani, "Cristoforo Madruzzo. Giovinezza e Studi, sua Elezione a Principe-Vescovo di Trento e Cardinal,” Archivio Trentino 20 (1905): 52-88; L. Dal Prà (Ed.) I Madruzzo e l'Europa 1539-1658. I Principi Vescovi di Trento tra Papato e Impero (Milan: Charta Editore, 1993).

24. The theory of justification by faith alone, developed by Luther, states that faith is a gift of God's mercy, which places the justice of Christ through faith on Christians, otherwise impossible to deserve. Actions are possible only if there is faith, which in any case is sufficient for justification. The Council of Trento will reaffirm the importance of faith for justification, but it reiterates that salvation is a condition that is achieved gradually, not an event achieved once and for all, at the beginning of the Christian experience, by the believer. Salvation is achieved by personal merit, in 
support for the ambitions of Charles $\mathrm{V}$ was also met with sympathy for the theories of Reginald Pole, an English cleric who had embraced the doctrine of justification by faith alone, one of the bulwarks of the Lutheran theses and the focal point of the Council's entire doctrinal discussion. ${ }^{25}$ There was also a great deal of fuss over the explicit consent given by Madruzzo to the translation of the Bible into the various national languages, so that the sacred text could be read by everyone, and not only by the ecclesiastical scholars who knew Latin. The relationship between the Protestant Reformation and the national languages would then prove to be one of the key proponents of the spread of the new Lutheran doctrine in Europe, which in turn led to a rediscovery of national identities. The opposition to Madruzzo was, therefore, not uncalled for, since it was understood that resolving the religious-linguistic question would be the starting point of social self-awareness which was very dangerous for the Vatican at a political level. Adriano Prosperi remembers what he proposed, for the positions to be taken among the Council's circles, to begin to observe that strange space that lies between the two parties puts different spaces in contact with each other. The marginality in which he had lived allowed Madruzzo to look with lucidity at the pretensions that were on either side of the border. He could then offer "a point of reference for those who hoped for a Council where they could finally talk openly about the serious problems of the moment and let the positive method of reform triumph." ${ }^{26}$ Unfortunately, the reasons for diversity prevailed over the hopes for cohesion; the power of Charles V collapsed rapidly and the pluralism of confessions in the individual territorial states was accepted precisely to set aside any idea of founding a universal monarchy. The subsequent division and belonging to one of the religious groups that was then being formed was precisely what was fundamental for future relations between state units in the late $16^{\text {th }}$ century.

the sense of a response to divine grace. On the theme see in particular V. Subilia, La Giustificazione per Fede (Brescia: Paideia, 1976); F. Ferrario and W. Jourdan, Per Grazia Soltanto. L'Annuncio della Giustificazione (Turin: Claudiana, 2005).

25. "Christopher Madruzzo, in the last years of his life, had often been heard to say that he was proud of two things "mainly in this world: one was to have served Charles V Emperor, the other to have loved and venerated the Cardinal of England", M. Bellabarba, "Il Principato Vescovile di Trento e i Madruzzo: 1'Impero, la Chiesa gli Stati Italiani e Tedeschi," in Dal Prà (Ed.) I Madruzzo e l'Europa 1539-1658. I Principi Vescovi di Trento tra Papato e Impero, 1993, 29. Some historians remember how much the bishop could be one of the "very authoritative exponents of the ecclesiastical hierarchy" who had become "unscrupulous propagandists" of doctrines that were manifestly unorthodox, reiterating that "some of the most prestigious exponents of the sacred college, often linked to the imperial party, did not cease to look at those doctrines with curiosity, interest and in some cases personal involvement". See M. Firpo, Riforma Protestante ed Eresie nell'Italia del Cinquecento (Rome-Bari: Laterza, 2004), 129-130; Firpo, Dal Sacco di Roma all'Inquisizione. Studi su Juan de Valdés e la Riforma Italiana (Turin: Edizioni dell'Orso, 1998), 64-104.

26. Prosperi, L'Eresia del Libro Grande. Storia di Giorgio Siculo e della Sua Seta, 2000, 90. 


\section{Castel Velturno, a Border Utopia}

The construction works on behalf of Madruzzo of Castel Velturno - a summer residence of the prince-bishop near Bressanone in South Tyrol - has been attested since 1577 under the direction of architect Matthias Parlati. ${ }^{27}$ The studies have retraced the construction history of the residence starting from an analysis of the Libro dei conti. It provides precise information about the artists who worked on the site, as well as on the works carried out and their completion reported in 1589, the year in which the castle can be said to be finished in all its parts. Castel Velturno consists of two floors in addition to the ground floor, used mainly as a warehouse. The decorative cycles of the rooms on the first floor can be traced back to Michele and Orazio da Brescia, while those on the second floor are named Pietro Bagnatore. The arrangement of the five rooms that make up the various floors follows the Oltradige scheme, with rooms symmetrically arranged on the sides of a central hall. What we intend to focus on in this essay is the choice of the iconographic programme of the pictorial decorations in the rooms of the castle, which forms a precise itinerary for the visitor to follow, divided into real cycles. In the eyes of Madruzzo, in Castel Velturno, what historically had not been possible to reach can happen. The residence is a real border space, a space that proposes a way of pacification. In this regard, the client's choice is to gather a large part of the iconographic programme from prints by Flemish artists of the time that represent the perfect union between Europe and Rome, as they were formed in the capital and then spread the Renaissance culture in the most remote areas of the Empire and acted as a glue between the centre and the border of Christianity ${ }^{28}$ (Figures 34).

27. On Castel Velturno, its composition and decorative cycles: N. Rasmo, "Le Pitture del Castello di Velturno," Alto Adige (1942): 82-100; L. Andergassen, Castel Velturno: La Residenza Estiva dei Principi Vescovi (Bolzano: Schnell Steiner Editore, 2010); S. Theil, Castel Velturno (Bolzano: Athesia Editore, 1984); K. Wolfsgruber, Castel Velturno: Costruzione e Decorazione (Bolzano: Soprintendenza Provinciale ai Beni Culturali, 1995); C. Limentani Virdis, "La Decorazione di Castel Velturno: Theatrum Totius Sapientiae," in L. Dal Prà (ed.) I Madruzzo e l'Europa 1539-1658. I Principi Vescovi di Trento tra Papato e Impero. Milan: Charta Editore, 1993, 268-277; S. Spada, "I Dipinti di Pietro Maria Bagnatore nel Castello di Velturno," in L. Dal Prà (ed.) I Madruzzo e l'Europa 1539-1658. I Principi Vescovi di Trento tra Papato e Impero. Milan: Charta Editore, 1993, 256-267.

28. See Limentani Virdis, "La Decorazione di Castel Velturno: Theatrum Totius Sapientiae," 1993, 269-270. 


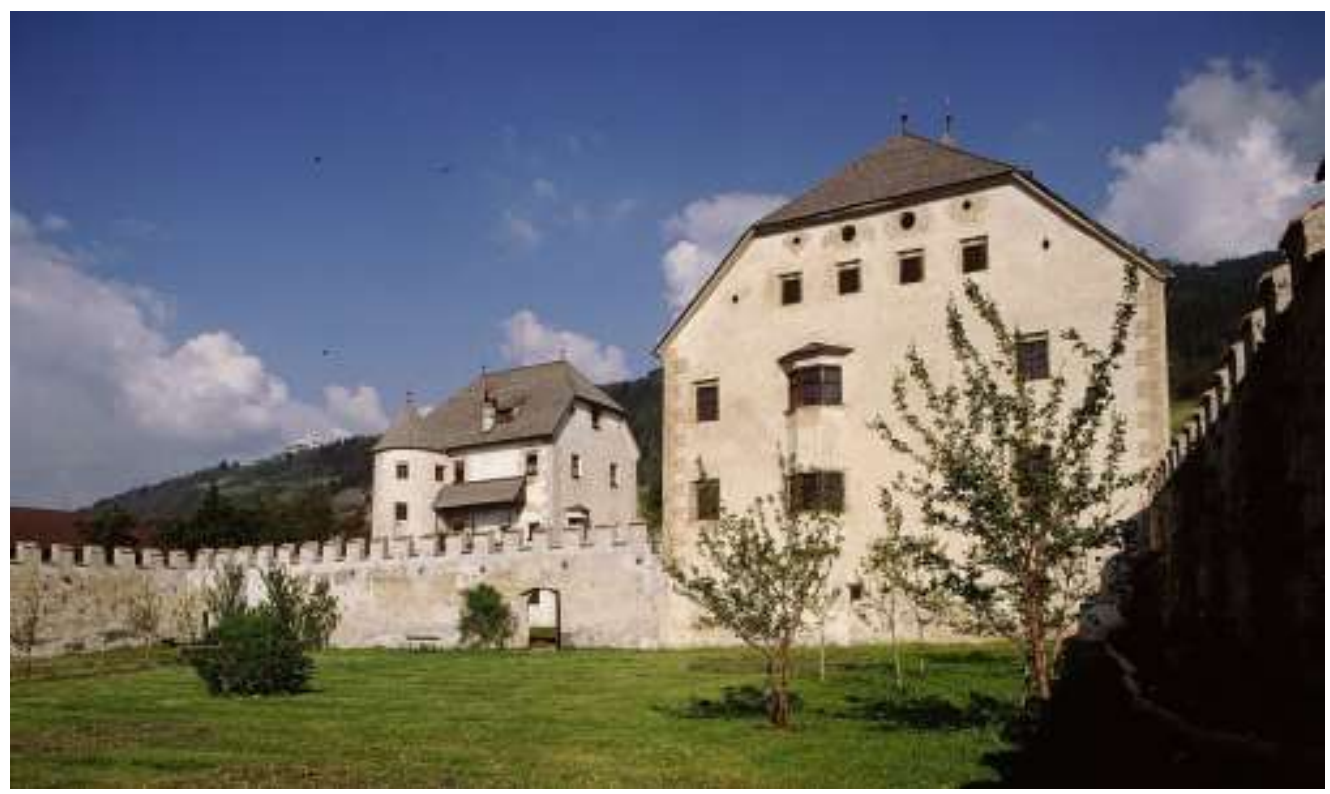

Figure 3. External View of Castel Velturno

Source: Autonomous Province of Bolzano - Cultural Heritage Office.

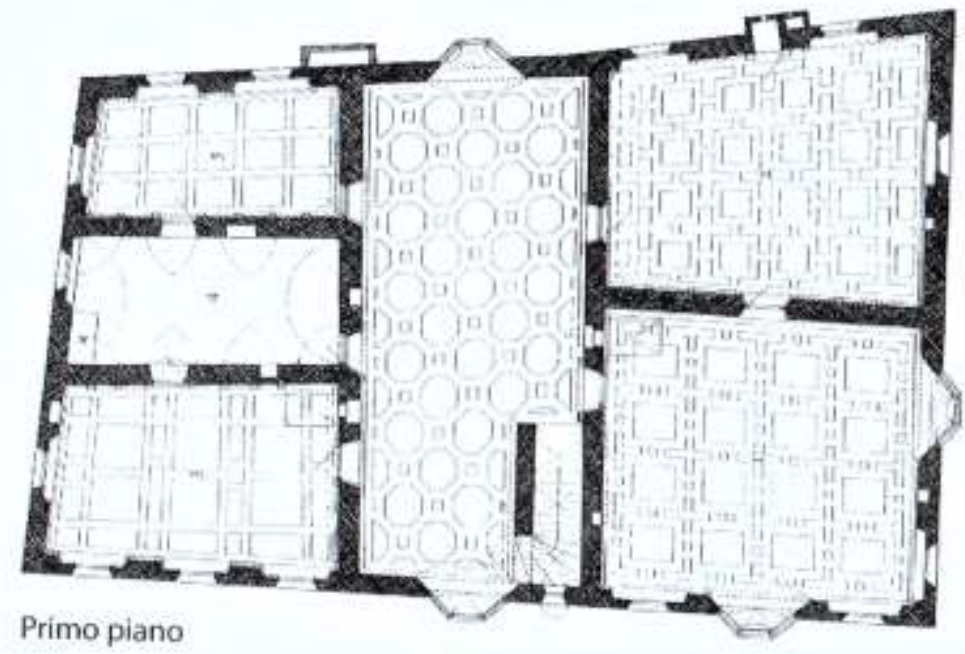

Figure 4. Blueprint of Castel Velturno (First Floor)

Source: Autonomous Province of Bolzano - Cultural Heritage Office.

\section{The "Fides" and the Dogmas of the Council of Trento}

The whole castle proposes, in the wall paintings, the continuous alternation between confessional subjects and profane allegories. The visitor is faced with allegories of the Sciences and Virtues in the first room. The second room contains remains of very faded decorations; the third room houses four panels with classical divinities: Jupiter, Juno, Mercury, Ceres and Proserpine, all accompanied by their attributes. In front of these, there are some panels among which the image of Fides 
stands out with torch and cross as opposed to Idolatry. The fourth room contains the representations of the Seven Sacraments, placed in front of the four episodes of the Parable of the Good Samaritan. In the final room, the pagan episodes return with paintings related to the Triumphs of Petrarch, the Four Seasons and episodes from the Stories of Aeneas. On the second floor, in the first room, in an almost mirror-like manner to that on the first floor, there are twelve panels on the Virtues that overcome the Vices, among which the painting representing the Christian Religion that conquers Idolatry is particularly noteworthy (Figure 5).

The second room includes a chapel, from where the visitor enters the third room, where the allegories of the four parts of the World and the five senses are represented. From the pagan repertoire, we pass again to scenes of a religious nature in the fourth room, all dedicated to a rich cycle with scenes from the Childhood of Jesus.

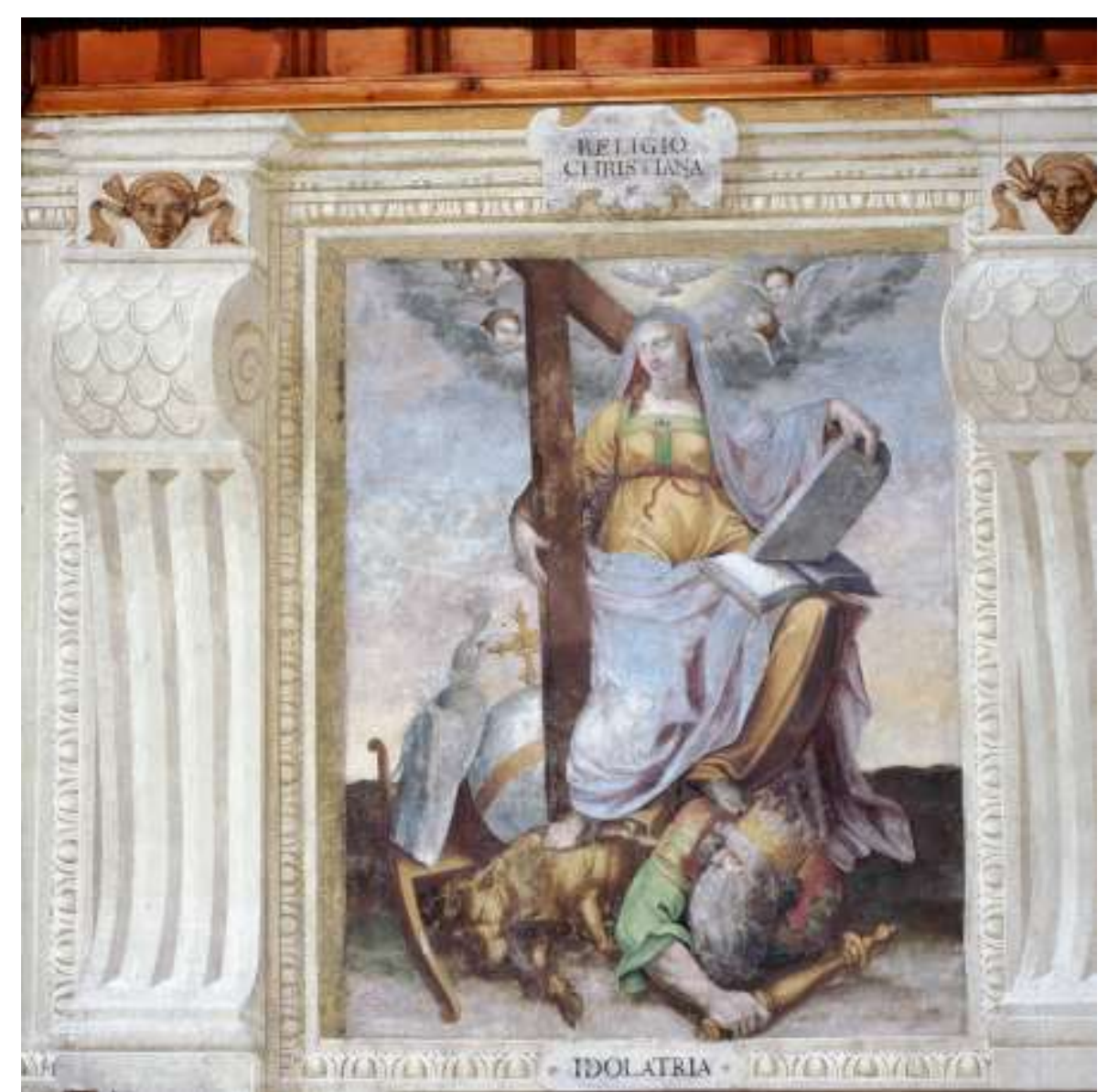

Figure 5. Pietro Bagnatore, Christian Religion wins over Idolatry, Detail of the Cycle of Virtues and Vices, Second Floor, 1584

Source: Autonomous Province of Bolzano - Cultural Heritage Office.

The atypical ascensional route proposed to the visitor, oscillating between the sacred and the profane, culminates in the fifth room, the so-called "Prince's room". This is the most important because it was used by the prince-bishop as a place of representation and a place for public audiences. 
The panels that decorate the room represent the Wonders of the ancient world, also taken from the famous series by Marteen van Heemskerck in 1570. To this some monuments are added that are not included in the traditional list, but are of great importance for the interpretation of the entire pictorial cycle: the Colosseum, an obelisk, the Trajan's Column, the Pyramid Cestia, the Temple of Jerusalem, the Tower of Babel, the allegory of Architecture with team and compass and finally the Saint Peter's Basilica (Figures 6-7).

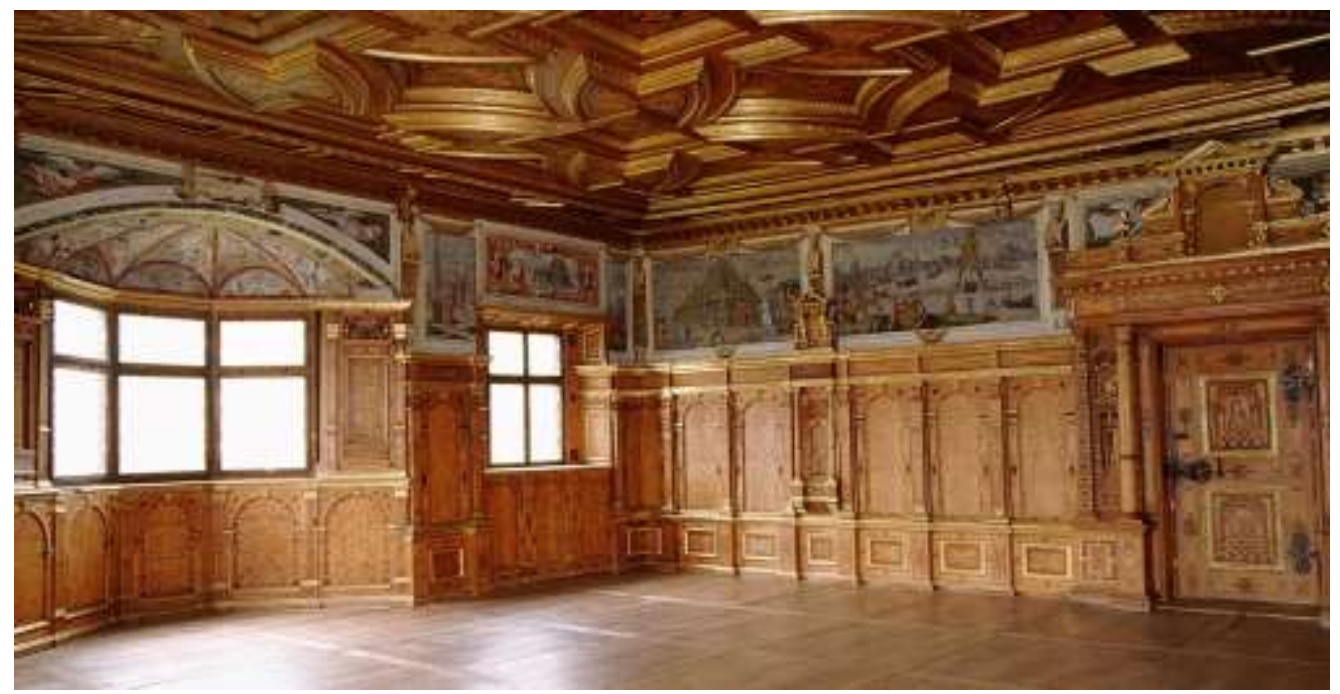

Figure 6. Corner view of the Prince's Room with Paintings of the Wonders of the Ancient World

Source: Autonomous Province of Bolzano - Cultural Heritage Office.

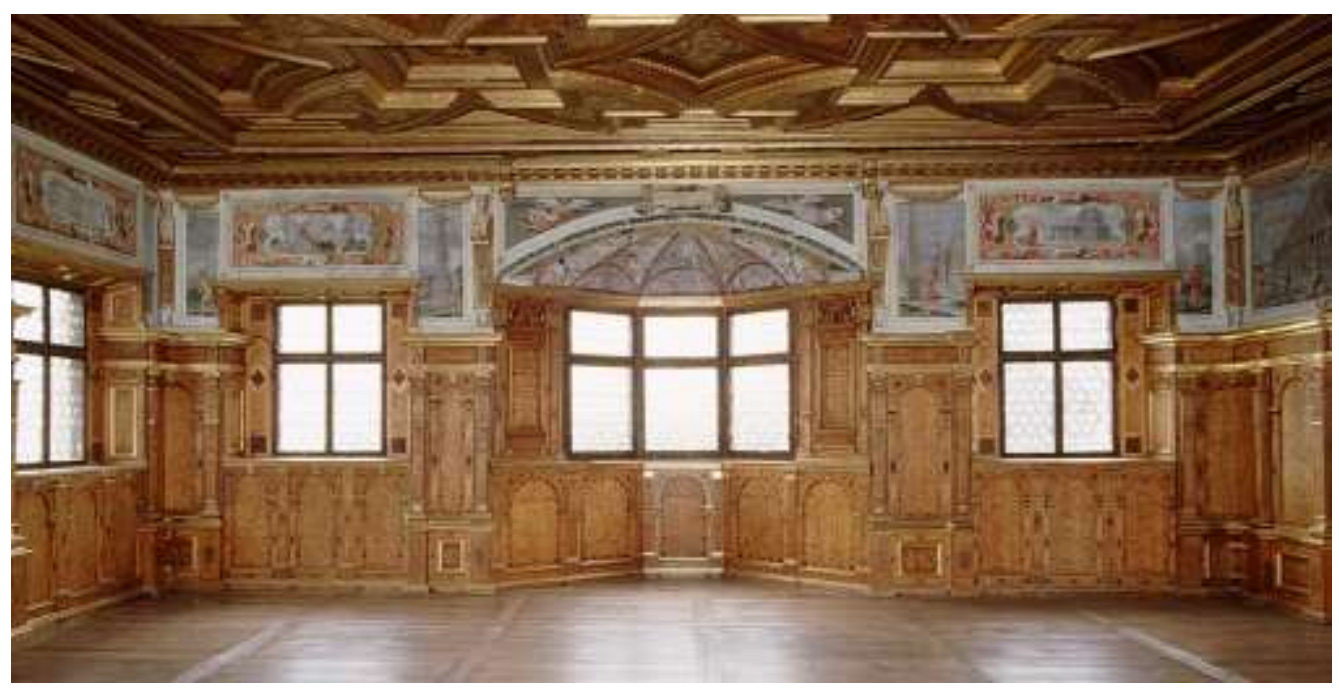

Figure 7. Detail of the Prince's Room with Panels of the Tower of Babel and St. Peter's Basilica

Source: Autonomous Province of Bolzano - Cultural Heritage Office.

The entire iconographic programme, according to Limentani Virdis, must be read in virtue of the contrast between Idolatry and Faith that would justify the presence of painted scenes such as the one in the north-west room on the first 
floor, where the winning Fides appears before the representatives of paganism. ${ }^{29}$ This character of "contraposition" can also be seen on other occasions, such as in the room dedicated to Virtues and Vices, where everything is a function of the Good-Evil contrast: the allegory of Power is opposed to Tyranny, Wisdom to Ignorance, Justice to Violence and so on. The scholar concludes by emphatically naming the iconographic programme of Castel Velturno Theatrum totius Sapientiae, in which the subjects of the painted scenes respond to the client's need for an ordered and severe encyclopaedic knowledge. Rather than a contraposition, it is possible to identify a co-presence of pagan and Christian in the whole iconographic programme studied and wanted by Madruzzo himself. This can only happen through a common thread that is given by the image of Fides. It is Fides that moves through the various rooms of the palace, bringing opposition on one side and co-presence on the other. The representation of the dogmas pronounced following the heated doctrinal discussions that took place in Trento is also evident. In particular, it is good to look at the cycle of the Seven Sacraments, one of the most important elements of Roman doctrine challenged by the Reformed. During the meetings of the second and third periods, the Council had set the number of sacraments at seven, putting an end to a confessional dispute of epochal importance. ${ }^{30}$ The depiction of the sacraments is almost literal in the room in the east wing on the first floor. See, for example, the sacrament of the Eucharist imparted here, just as contemplated by the Council of Trento, even outside the celebration of Mass $^{31}$ (Figure 8).

29. Limentani Virdis, "La Decorazione di Castel Velturno: Theatrum Totius Sapientiae," 1993, 272.

30. In several sessions, the general doctrine of the seven sacraments, considered to have been instituted by Jesus Christ and to be effective independently of their execution (former works), was reaffirmed. While the Council failed in its task of recomposing the Protestant schism and restoring the unity of the Church, it certainly provided an organic and comprehensive doctrine on the sacraments, which had been so much challenged by Luther. The sessions reserved for discussion of the sacraments were as follows: VII (1547), XIII (1551), XIV (1551), XXI (1562), XXIV (1563).

31. In fact, a priest is represented before an altar, who gives communion to three kneeling believers. It is stated in the acts of the Council: "Furthermore, the Holy Council declares that with very pious and religious thought it was introduced in the Church of God to celebrate this very noble and venerable sacrament every year with singular veneration and solemnity and with a particular festivity, and to carry it with reverence and honour through the streets and public places, in processions". Concilio di Trento, Decreto sull'Eucarestia, Sessione XIII, Capitolo V, Del Culto e della Venerazione Dovuti a Questo Santissimo Sacramento (11 Ottobre 1551), 221. 


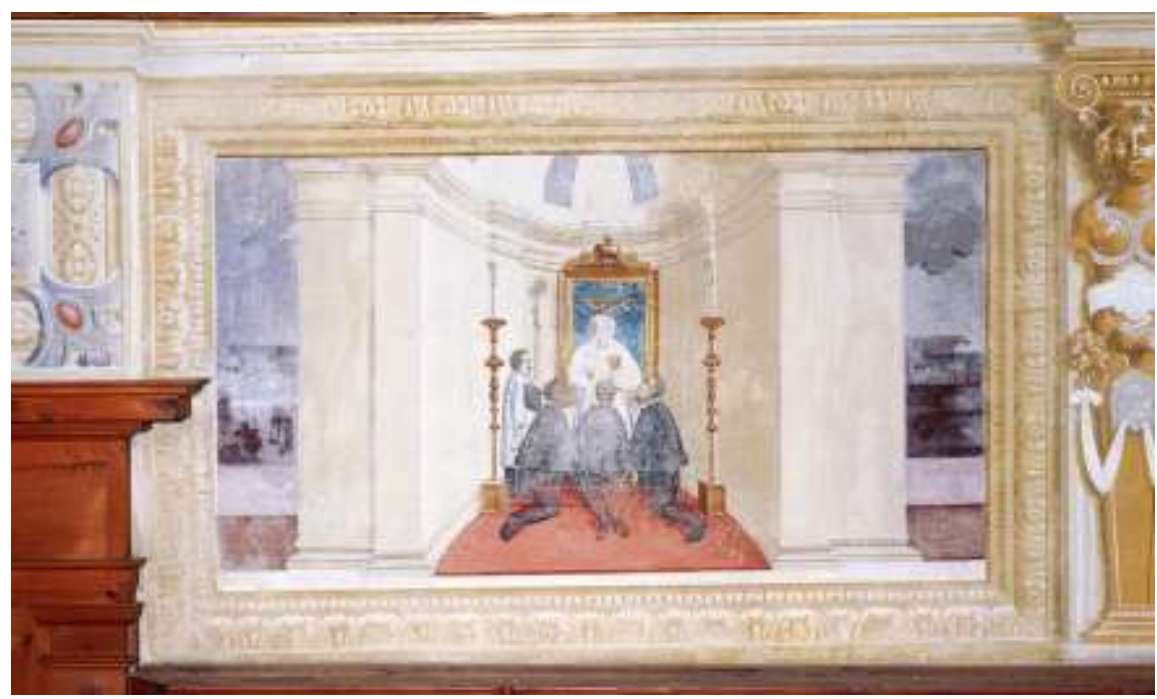

Figure 8. Orazio e Michele da Brescia, The sacrament of the Eucharist, Detail of the Cycle on the Sacraments, 1582-1583

Source: Autonomous Province of Bolzano - Cultural Heritage Office.

Finally, it is very interesting to examine the iconographic choice made for the decoration of the "prince's room", with the cycle dedicated to the pagan theme of the Wonders of the World. The seven Wonders of the classical canon are flanked by the eighth Wonder par excellence: the Colosseum, celebrated by van Heemskerck himself in his series of Octo mundi miracula. But what is most surprising is the fact that this panorama of famous monuments of Antiquity widens to include other archetypes present in the caput mundi city, such as the Trajan's Column and the Obelisks (Figures 9-10).

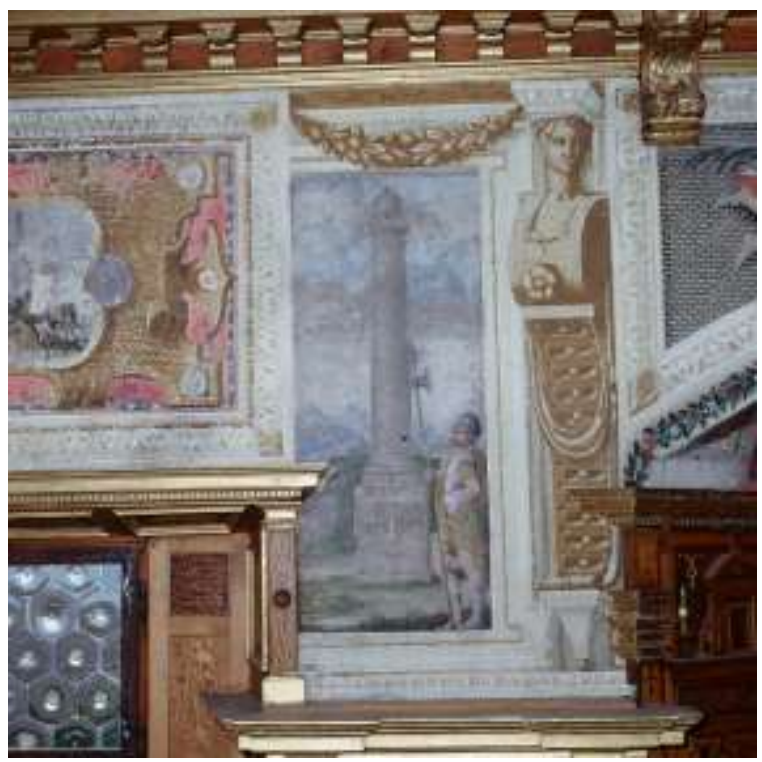

Figure 9. Pietro Bagnatore, Trajan's Column, Detail of the Wonders of the World Cycle, Prince's Room, Second Floor, 1584

Source: Autonomous Province of Bolzano - Cultural Heritage Office. 


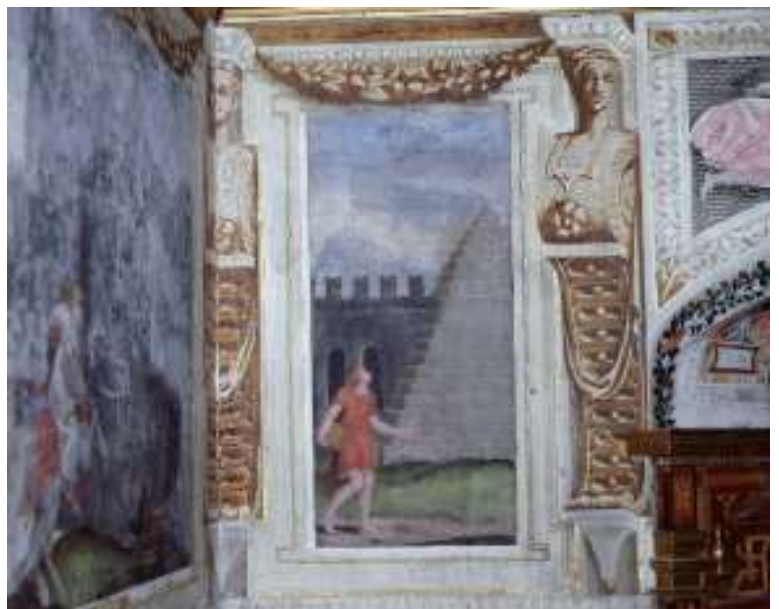

Figure 10. Pietro Bagnatore, Piramide Cestia, Detail of the Wonders of the World Cycle, Prince's Room, Second Floor, 1584

Source: Autonomous Province of Bolzano - Cultural Heritage Office.

Anticipating by about a century apart, the Kircherian juxtaposition between sacred and profane within the theme of the Mirabilia, this room becomes a real panorama of Wonders that sweeps towards the remotest Antiquity of the Christian world welcoming the ancient Biblical Wonders such as the Tower of Babel and the Temple of Jerusalem. For his personal room, Cristoforo Madruzzo still plays on the theme of the coexistence of two themes dear to him: Christian Fides and the choice of a pro-Imperial policy. The theme of Wonders appears as an important political support. These architectural works are the perfect expression of the "Ars regia", of that art born from the will of important political figures who see the works themselves as a manifestation of their power. It is not only the seven classical Mirabilia to be placed side by side in the painted scenes by the clients but the same figurative treatment is also reserved to the Christian Wonders. Next to the Tower of Babel is the Babylonian King Nebuchadnezzar while Solomon is at the side of the Temple of Jerusalem (Figures 11-13).

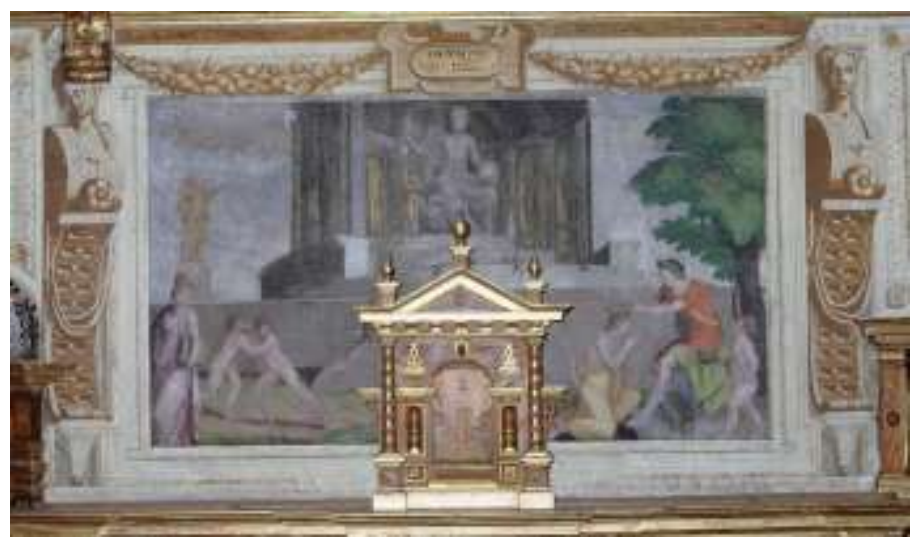

Figure 11. Pietro Bagnatore, The Statue of Zeus in Olimpia, Detail of the Wonders of the World Cycle, Prince's Room, Second Floor, 1584 Source: Autonomous Province of Bolzano - Cultural Heritage Office. 


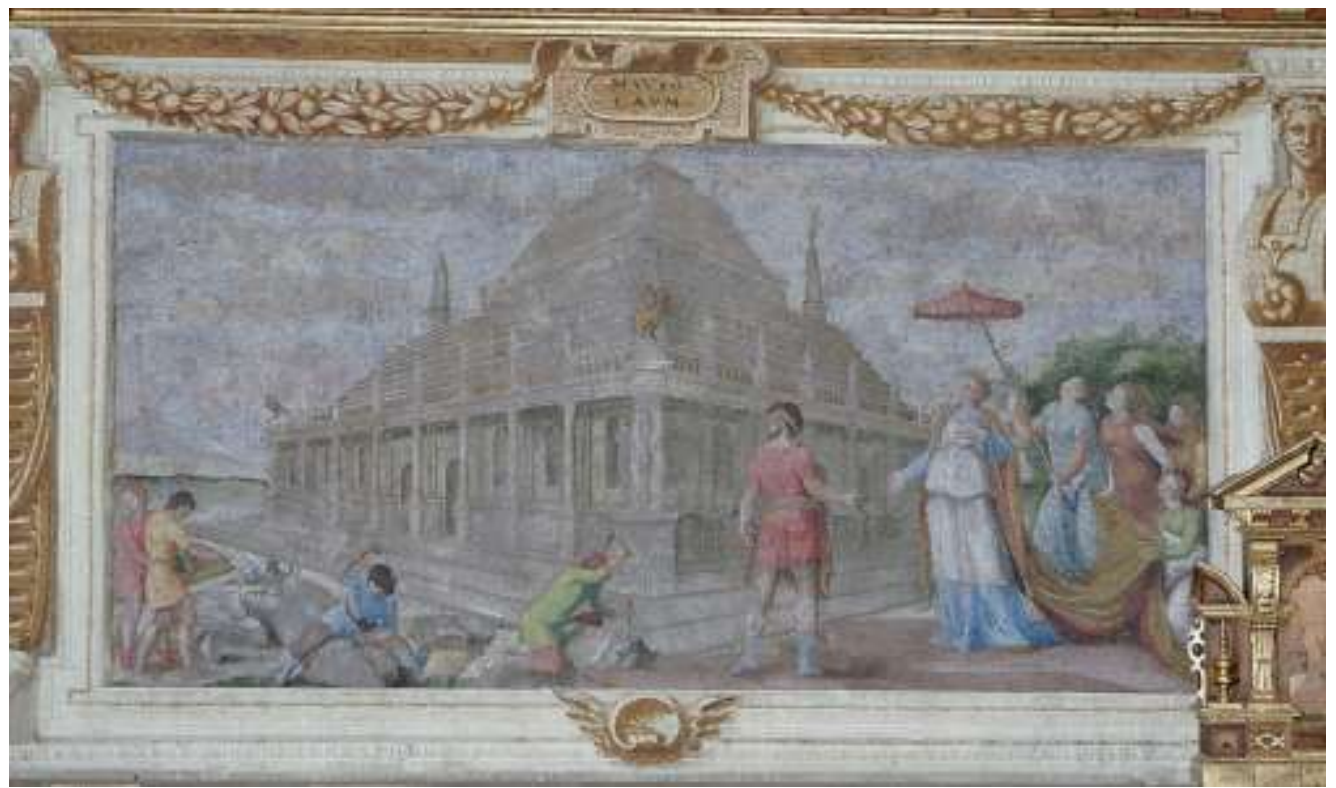

Figure 12. Pietro Bagnatore, The Mausoleum of Alicarnassus, Detail of the Wonders of the World Cycle, Prince's Room, Second Floor, 1584 Source: Autonomous Province of Bolzano - Cultural Heritage Office.

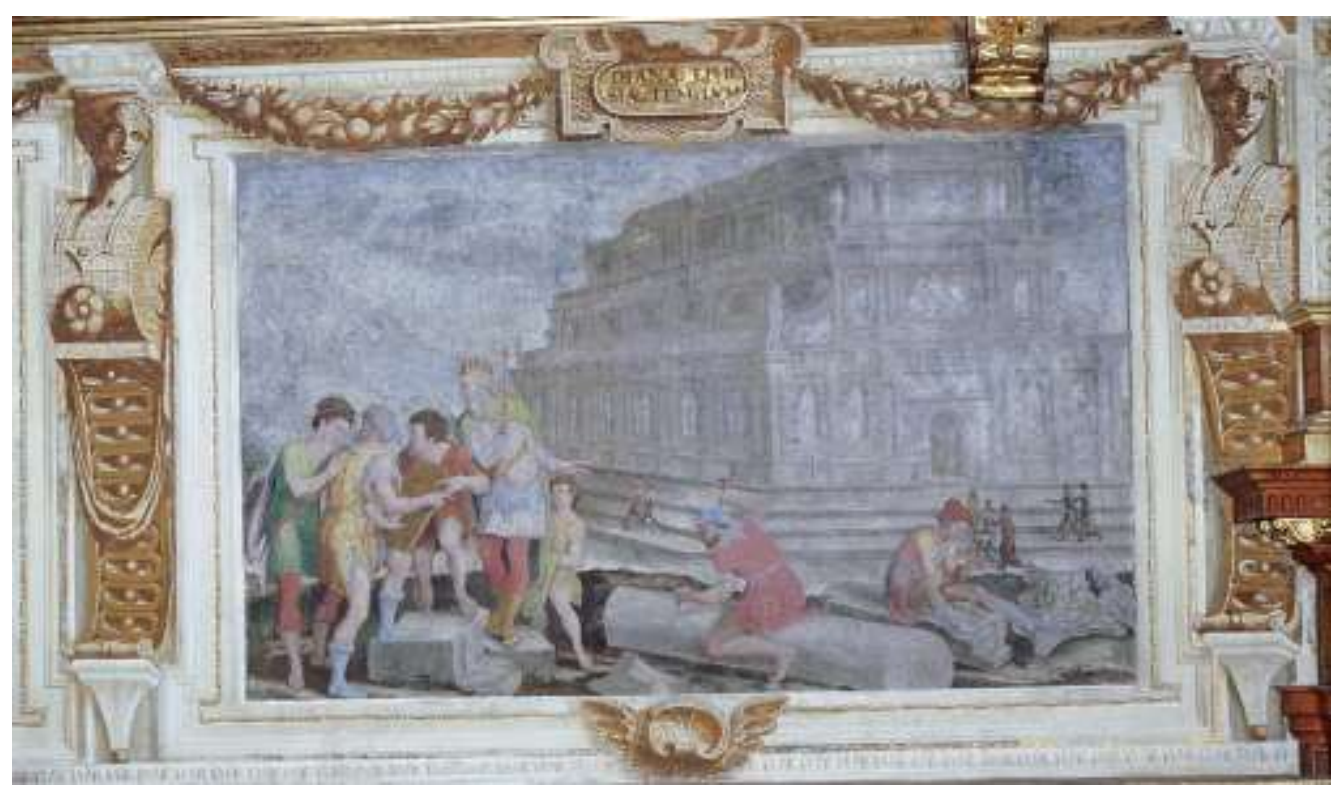

Figure 13. Pietro Bagnatore, The Temple of Artemis at Ephesus, Detail of the Wonders of the World Cycle, Prince's Room, Second Floor, 1584

Source: Autonomous Province of Bolzano - Cultural Heritage Office.

If the presence of negative archetypes of the Christian world (such as the Tower of Babel) recalls the weakness of those ancient Wonders built "without faith", in the "prince's room", it is also possible to look to the future, to the construction of that new Wonder. This on the one hand is the universal home of Christian Fides and on the other is the place where the greatest names of the artistic genius of the time alternate to the new St. Peter's Basilica. In a few words, 
the multiplicity of artistic inspiration blends into a single large casket in honour of Fides. It is not difficult to note how Madruzzo, in his decision to emphasise the decorative cycles of his castle with the recurring image of Fides, wishes to underline how convinced he is, supporting Lutheran beliefs that only Fides is the founding element of Religion capable of combining more distant positions and cultures. Faith must not be an element of rupture (as happened in the Council concerning the theories on justification). On the contrary, faith must be that binder which the Madruzzo family blindly believed. It was to be the mission of their bishop's policy when starting from the sixties of the $16^{\text {th }}$ century, they went to the court of Emperor Ferdinand more and more often to convince him to publish the Tridentine norms. There could not have been a better choice to represent Christopher's thought. In addition to being a tribute to van Heemskerck's famous drawing, St. Peter's Basilica is deliberately still under construction. This is not only because at the time of the execution of the mural paintings, it was not yet finished, but because the ideal that this work embodies, the universality of doctrine, has not yet been completely fulfilled. It is a battle to be won with the courage of those who challenge themselves for it. This is why the image of the building site is flanked by the two figures that, more than others, had been the driving force behind the architectural enterprise: Julius II and Michelangelo, represented here as a sculptor. As Zanini writes, "the boundary exists only in function of a centre." 32 Therefore, Castel Velturno exists only in function of its centre, Rome, the seat of Christian doctrine. History has also testified that the dream of Christopher and his family will never come true and that the peace of Westphalia reached in 1648 will represent the "end of the Madruzzian century." 33 With the fall of religious differences, confessional schemes and the need for mediation between the Germanic and Italian parts, the role of Madruzzo also lost its usefulness. However, Castel Velturno remained a significant utopia on the border between apparently opposing worlds.

\section{The Bi-National Community Skyscraper by C. Tzu Wei Chiang and A.M. Guerrero}

The border is very often understood as a fence, an element of definition of a closed and protected space that with its construction regulates the way the space is crossed. The fence builds a frontier, a complex dialogue between inside and outside, when it defines rules between being inside and moving outwards: "The fence circumscribes and regulates through the doors an open space that is considered in some way privileged and different from its antithesis: the outside." Faced with the danger of disorder, the clearest spatial response is found in the request made by many, both in the United States and in Europe, for a sort of right

32. Zanini, Significati del Confine. I Limiti Naturali, Storici, Mentali, 1997, 43.

33. Bellabarba, "Il Principato Vescovile di Trento e i Madruzzo: l'Impero, la Chiesa gli Stati Italiani e Tedeschi," 1993, 42.

34. M. Scolari, "Principi Compositivi," Recinti, Rassegna, no.1 (1979), 41. 
of enclosure. ${ }^{35}$ This right would like to see legislatively recognized the possibility for anyone to get out of a territory, to isolate themselves from a whole, segregating themselves in their own idealized space: "For those who belong to this exceptional space, everyday reality becomes the reality inside the camp, behind its border. Everything else, what remains outside, beyond the fence, the reality of others, is transformed into something increasingly distant and indifferent.",36

\section{The "Walls of Shame"}

Today in the world there are many walls built to prevent and hinder the passage of civilians between different territories. "Wall of shame" is a phrase used to define these structures with a critical meaning. Shame refers, depending on the case, to those who took care of their construction, the people who suffered the consequences or the circumstances that led to their construction. In 1961, W. Ulbricht gave the order to block the road that marked the border between the East and West sectors of Berlin. A few days later, the Berlin Wall was born. For 28 years, it was the symbol of the Cold War, which had politically divided the world into two hemispheres: eastern and western. It was above all a symbol of hostility, segregation and incommunicability. ${ }^{37}$ However, despite that the wall has fallen, others remain standing. Walls that break families and entire peoples, that shatter identities, that deny hope. It starts with the one more than a thousand kilometers long, known as the wall of Tijuana, a metal sheet that covers a third of the border between the USA and Mexico. It was erected against the citizens of Central and South America, who are trying to reach the U.S. through the Mexican border to escape from hunger and misery still widespread in the Mexican state. No less famous is the mighty wall, $4 \mathrm{~km}$ wide, erected by the South Koreans, which divides Korea in two. This wall was created in 1977 and extends for $240 \mathrm{~km}$, for the total width of the peninsula. Not to be forgotten is the $27 \mathrm{~km}$ long Malaysia/ Thailand wall, built by the Thais on the border with Malaysia, to counter the arrival of weapons intended for the Muslim and separatist guerrillas in the south of the territory. According to official sources, the Zimbabwe/Botswana wall, an electrified barrier is created, to prevent wild animals from passing from one country to another. But in reality, it was built to prevent refugees, escaping the ethnic massacres of Zimbabwe, from entering Botswana, a small nation with one of the highest incomes in Africa. And then, there were many small "Gaza Strips": villages of the African communities San and Herero cut in two or deprived of water access roads, where bloody guerrillas are constantly taking place. On the one hand, the villagers are trying to remove that intolerable barrier. On the other, the army of Botswana committed to enforce the demarcation of the border. In Central

35. S. Boeri, "Border Device(s): A Visual Essay," Borderlands: Identity, Culture and Belonging 120 (2005): 28-39.

36. Zanini, Significati del confine. I Limiti Naturali, Storici, Mentali, 1997, 130-131.

37. On the Berlin Wall and the studies after its fall see: P. Galante and J. Miller, The Berlin Wall (New York: Doubleday \& Co., 1965); R. Koolhaas, The Berlin Wall as Architecture ('Field Trip', SMLXL, 1995); P. Major, Behind the Berlin Wall: East Germany and the Frontiers of Power (Oxford: Oxford University Press, 2010); J. Ward, Post-Wall Berlin: Borders, Space And Identity (London: Palgrave Macmillan, 2011). 
Asia, on the other hand, there is a wall, equipped with sensors and video surveillance, erected by Uzbekistan to assert sovereignty over certain territories disputed with Kyrgyzstan. Between India and Pakistan, there is one of over three thousand kilometers that divides the two countries. Pakistan has built a 2,400 km barrier to control its border with Afghanistan while the Iranian government is completing the construction of a wall on the border with the Pakistani Republic. After six years of hard work, the wall dividing India and Bangladesh has also been inaugurated: an iron curtain 4,000 km long to curb immigrants, stop terrorists, drug traffickers and arms dealers. Morocco, too, is not free of walls. Around the Sahrawi region, a great bastion also known as the "safety belt" extends for almost $4,000 \mathrm{~km}$. Its function is to protect the country from the attempts of infiltration by the Polisario Front into the territories militarily occupied by Morocco. In the Middle East, Saudi Arabia has been no less: since 2003, it has been separated from Yemen by a belt made of reinforced concrete and equipped with electronic control apparatus, to block the illegal immigration of the Yemeni population. Another 900 km long ultra-modern barrier was created by Saudi Arabia in 2006 on the border with Iraq. And then there is the Kuwait/Iraq wall. Kuwait has reinforced the already existing $215 \mathrm{~km}$ long wall on the border with Iraq. And, again, the fence of the United Arab Emirates, built along the entire border, lines with the Sultanate of Oman. The "Walls of Shame" are also present in Europe; for example, the walls that divide Protestants and Catholics in Ireland (the so-called Peace Lines). When they were erected in the 1970s, they caused the deportation of entire families between the two areas. Between the Middle East and the West stands the electrified barrier that Spain has erected to block the passage of Moroccan or subSaharan immigrants. A double barrier stands from 4 to 6 meters high around the city of Ceuta and Melilla, where the pressure of millions of men on their way from sub-Saharan Africa is concentrated.

Thirty-one years after the fall of the Berlin Wall, Europe finds itself much more walled in than before. A thousand kilometers of weirs, fences, barbed wire and electrified nets have sprung up everywhere. The Balkans serve as a key part of the migration route from Turkey and Greece to Western and Northern Europe, and the UN's migration agency, IOM, estimates that nearly 22,000 asylum seekers and migrants are currently stranded in the region. Since the start of Europe's migrant crisis in 2015, at least 800 miles of fences have been erected by Austria, Bulgaria, Greece, Hungary, Macedonia, Slovenia and others - a rapid reaction in front of millions of people arriving in Europe from war zones from Afghanistan to Syria. These arrivals fed into a charged political environment over migration during the pandemic and led European countries to increase its military presence along borders to help fight illegal migration.

\section{The Project}

The walls, which over time have taken on the role of visible and invisible barriers can be rethought as a real threshold, a place destined to meet and open up to the differences in order to overcome the crisis caused by the closure of borders: "But can a new form of citizenship become the frontier that allows the cohabitation 
between different identities while safeguarding the confrontation with them?"38 Since the early 2000s, architects Ronald Rael and Virginia San Fratello have developed numerous proposals for interventions and alternatives to the United States-Mexico border wall (Figures 14-15).

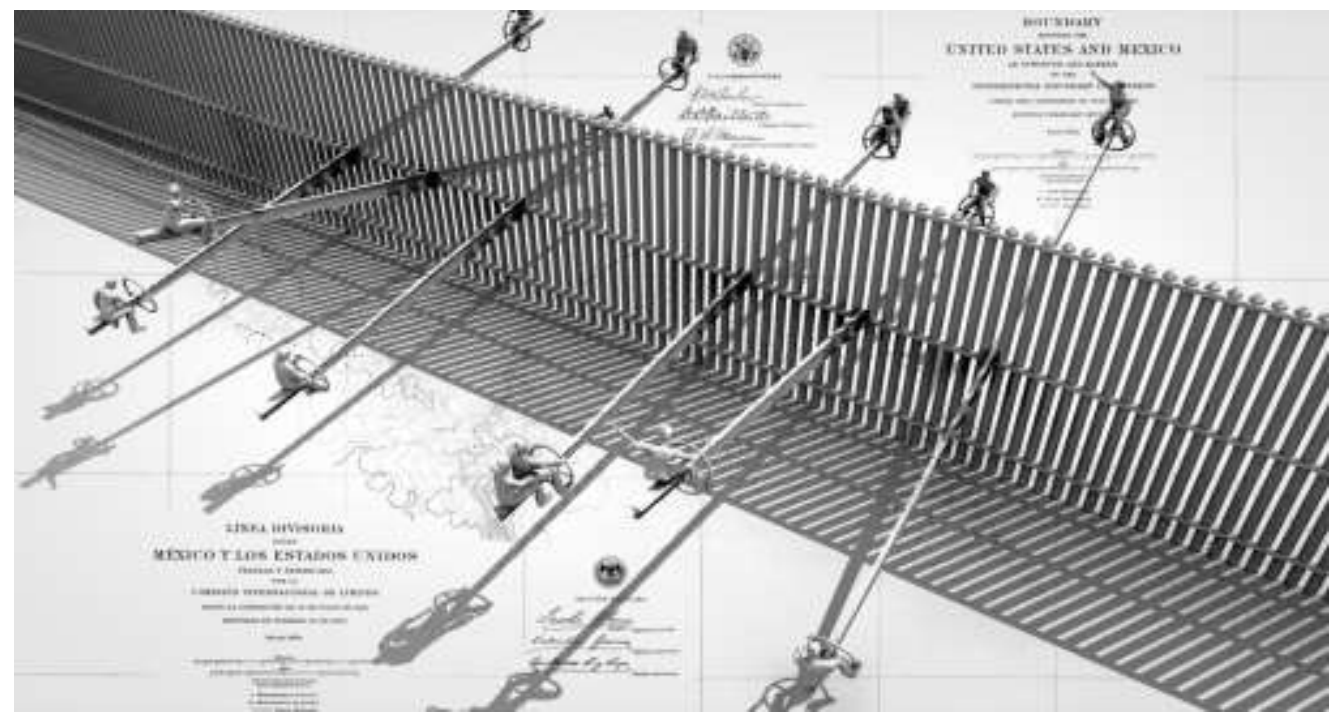

Figure 14. Ronald Rael and Virginia San Fratello, Transforming the Border Wall into a Teeter-Totter, USA-Mexico, 2019

Source: https://dezignark.com/.

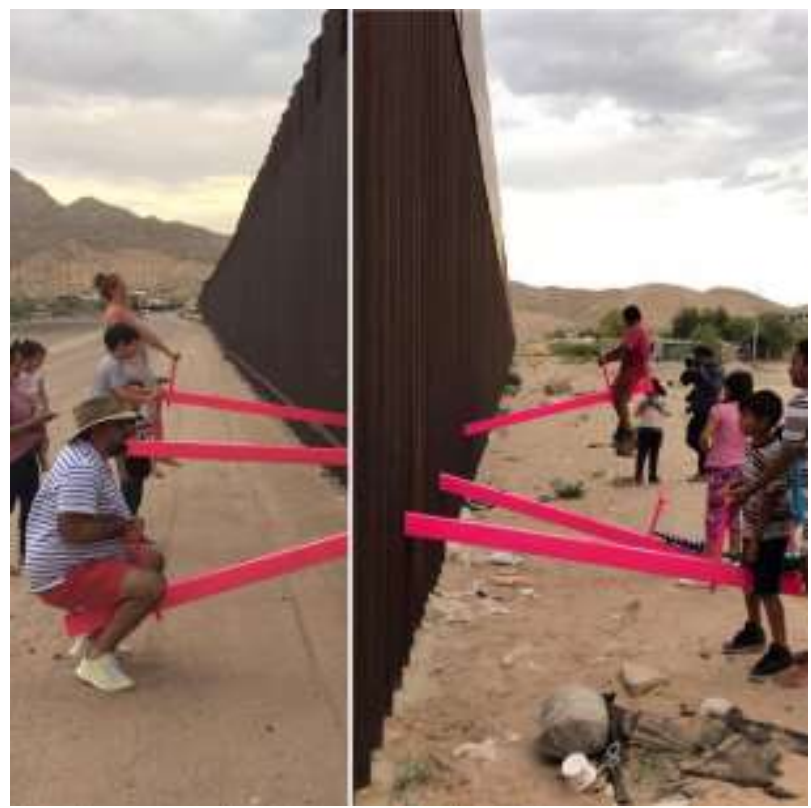

Figure 15. Ronald Rael and Virginia San Fratello, Transforming the Border Wall into a Teeter-Totter, USA-Mexico, 2019

Source: Wikimedia Commons.

38. Zanini, Significati del Confine. I Limiti Naturali, Storici, Mentali, 1997, 86. 
Many of their designs were inspired by stories of people who, on both sides of the border, transform the wall, challenging its existence in remarkably creative ways. Among the most famous ones, is the installation created using three pink swings in the boundary wall for families to play on. ${ }^{39}$ A similar and exemplary project in this sense is the Bi-National community skyscraper by architects, Charles Tzu Wei Chiang and Alejandro Moreno Guerrero of Taiwan, presented in 2019 at the "eVolo skyscraper competition". Established in 2006, the annual Skyscraper Competition is one of the world's most prestigious awards for highrise architecture. It recognises outstanding ideas that redefine skyscraper design through the implementation of novel technologies, materials, programs, aesthetics, and spatial organisations; along with studies on globalisation, flexibility, adaptability, and the digital revolution. It is a forum that examines the relationship between the skyscraper and the natural world, the community and the city. ${ }^{40}$ In 2019, one of the projects that received the honourable mention was the BiNational community skyscraper. The recent American government intends to enhance the construction of the border between Mexico and the U.S. to reinforce control. The barrier, which runs for miles along the border between Tijuana and San Diego (the size would be comparable only to the Great Wall of China) began to be built in 1990 cutting through deserts, mountains, rivers and cities. It is made of metal sheet, two to four meters high, and is equipped with very high-intensity lighting. A network of electronic sensors and night vision equipment is connected to radio to the US border police, who also use a permanent surveillance system with armed vehicles and helicopters. According to the data from Mexico's National Human Rights Commission, five thousand people have died in an attempt to cross the border in search of a more dignified existence. There are many stories regarding how such borders separate family members who hold different citizenship, or work and live on different sides of borders. This proposal aims to transform the perception of political borders from the boundary of separation to gathering for connection. Friendship Park is located next to the border between San Diego and Tijuana, as one of the locations where many separated families meet from both sides of the border. In the 1900s, there is no well-defined border but only patrols to control for access. Many travel back and forth to meet their family during weekends. Later, a metal fence was constructed to establish the border. In the 1990s, an additional metal mesh had been applied to prevent physical contact for illegal activities. Despite seeing each other through a metal mesh almost like seeing prisoners in jail, families are still willing to travel far to reunite on the border. This proposal suggests an "In-between zone" above the border fence, which is based on a temporary scaffolding structure and can be expended or reduced in size according to needs. With respect to legal regulation and the political situation, such a zone can be accessed with control of shafts of a staircase and allows families not only to meet up but hug and touch each other to share their moments together. As it serves as the platform for opportunities of interaction and communication, it enhances the interpersonal relationship and

39. See https://dezignark.com/blog/transforming-the-border-wall-into-a-teeter-totter-rael-sanfratello-artist-stories/. [Accessed 27 September 2020.]

40. See http://www.evolo.us/category/competition/. [Accessed 27 September 2020.] 
encourages a communal gathering space with a bi-national identity. As nationality or working and living status should not be the reason for the restriction of families to reunite, this project intends to help people who face the situation of separation of many families, as well as provide more humanised gathering space to meet on the border. Instead of constructing a structure of obstacle like a wall to reinforce control, the situation might be altered if a better architectural system can be provided and a better control method can be employed. A better outcome such as a bi-national community can be expected and encouraged to form (Figures 16-17).

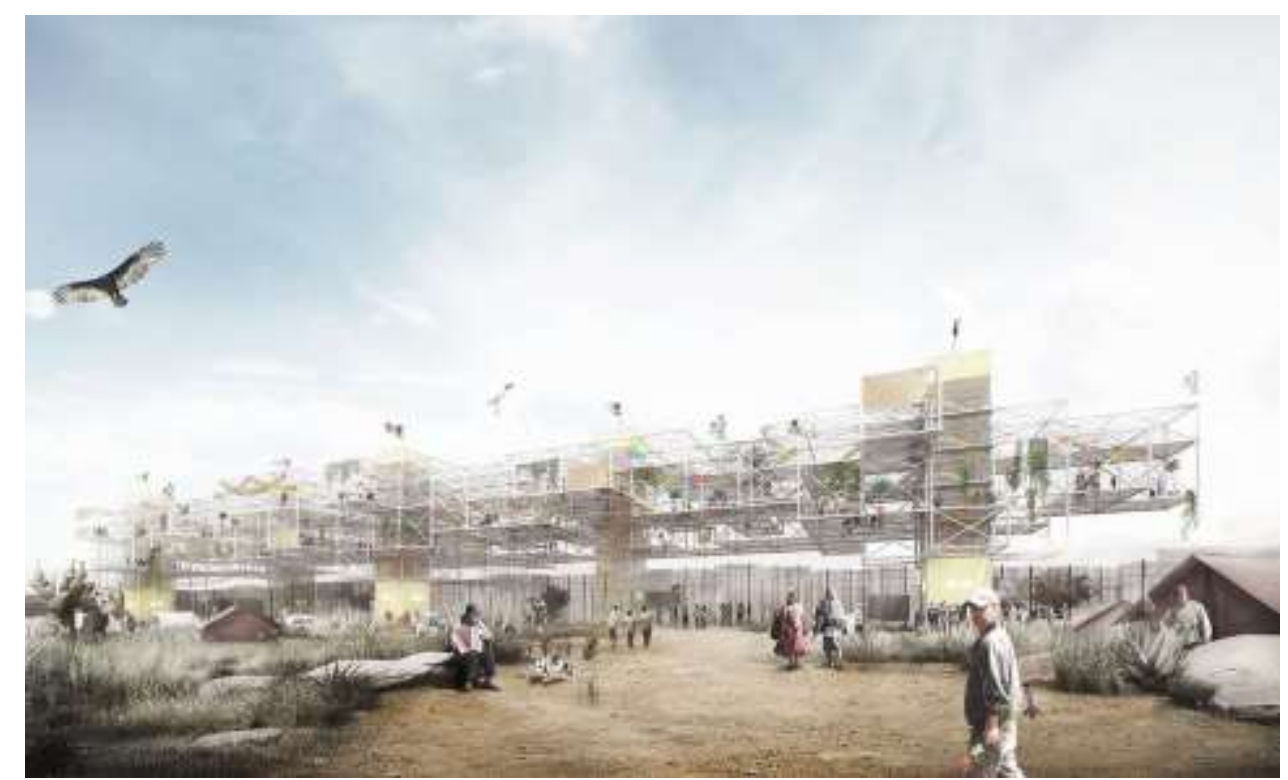

Figure 16. C. Tzu Wei Chiang, A. Moreno Guerrero, Bi-National Community Skyscraper, Project Hypothesis

Source: eVolo Competition 2019 (http://www.evolo.us/category/competition/).

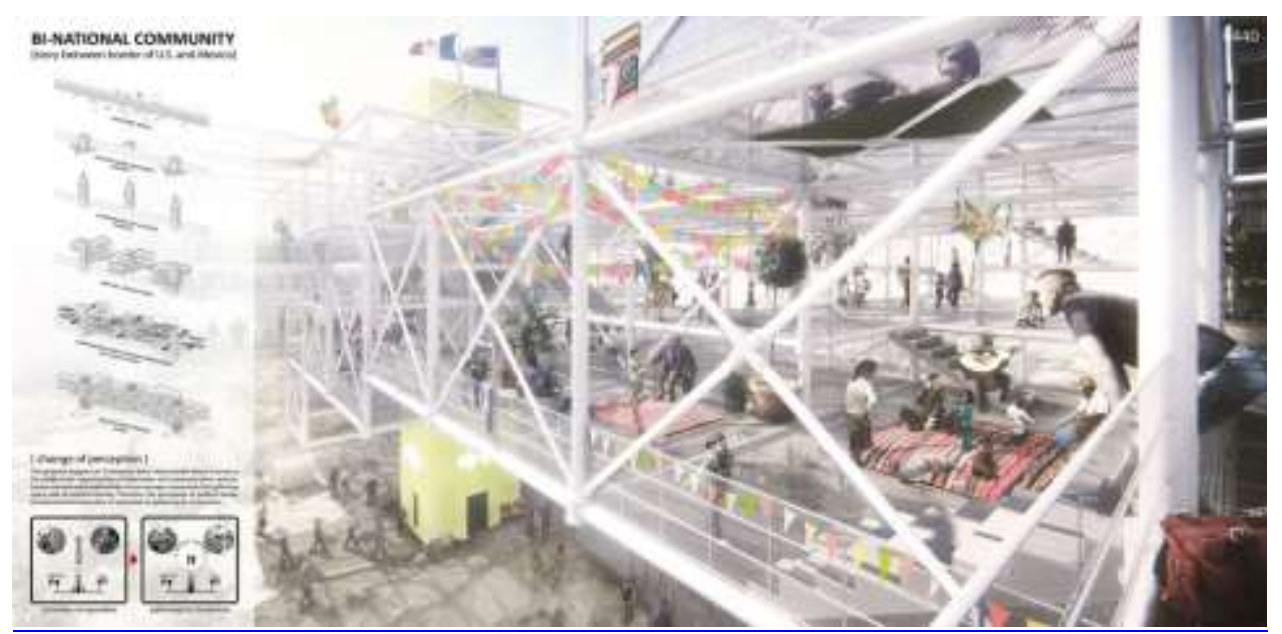

Figure 17. C. Tzu Wei Chiang, A. Moreno Guerrero, Bi-National Community Skyscraper, Project Hypothesis

Source: eVolo Competition 2019 (http://www.evolo.us/category/competition/). 


\section{Conclusions}

The three case-studies proposed, deliberately taken from very distant historical periods, help to understand that from an invisible place of separation to a space of misunderstanding, the border has also been understood in the past as the place of diversity, where different social groups and different ethnic groups meet and try to find a common modus vivendi, accepting each other. The frontier as a "space between two spaces" takes on positive and proactive characters and meanings, since it offers itself as a place of opportunities to undertake new experiences and new activities beyond the boundaries of tradition. Architecture, understood first of all as an instrument of measurement, is the ideal means to advance a semantic shift, proposing projects aimed at making the border a habitable place. Rethinking the border, nowadays, means making people understand that there is a mutual advantage in recognising the values of both sides. It would become not only a place but a real instrument to keep the dialogue open, beyond the respective ideological, religious or cultural schemes.

"This is where the modern world is born, and since everyday life requires a reasoned range of boundaries within which individual, family, community, city, regional, national and world life can take place, it is necessary that these boundaries are once again thought out and realised, and that they work both ways: open in certain circumstances, closed in certain others, like the simplest and oldest border, the door between two neighbouring rooms."

\section{Acknowledgments}

I would like to remember that this essay is the result of research funded by the European Union, European Regional Development Fund, PON Aim, Research and Innovation, International and Attraction mobility (2014-2020).

\section{Bibliography}

Albrecht, B. and L. Benevolo. I Confini del Paesaggio Umano. [The Boundaries of the Human Landscape.] Rome-Bari: Laterza, 1994.

Andergassen, L. Castel Velturno: La Residenza Estiva dei Principi Vescovi. [Castel Velturno: The Summer Residence of the Bishop Princes.] Bolzano: Schnell Steiner Editore, 2010.

Angelillo, A. and C. Menato. Città di Confine. Conversazioni sul futuro di Gorizia e Nova Gorica. [Border towns. Conversations about the future of Gorizia and Nova Gorica.] Portogruaro: Ediciclo, 1994.

Augè, M. Tra i Confini. Città, Luoghi, Integrazioni. [Between the Borders. Cities, Places, Integrations.] Milan: Mondadori, 2007.

Bammer A. "A Peripteros of the Geometric Period in the Artemision of Ephesus." Anatolian Studies 40 (1990): 137-160.

Barbanera, M. "Favole Antiche e Mitologie Moderne. Le Competizioni Artistiche nella Storia dell'arte Greca." [Ancient Fables and Modern Mythologies. Artistic

41. Albrecht and Benevolo, I Confini del Paesaggio Umano, 1994, 115. 
Competitions in Greek Art History.] Atene e Roma. Rassegna dell'Associazione Italiana di Cultura Classica VIII, no. 1-2 (2014): 7-31.

Boeri S. "Border Device(s): A Visual Essay." Borderlands: Identity, Culture and Belonging 120 (2005): 28-39.

Bozzoni, C., Pardo, V. F., Ortolani, G. and A. Viscogliosi. L'Architettura del Mondo Antico. [Architecture of Ancient World.] Bari: Laterza, 2006.

Canizaro, V. B. Architectural Regionalism: Collected Writings on Place, Identity, Modernity and Tradition. New York: Princeton Architectural Press, 2012.

Cavallotto S. "Luterani e Cattolici, Storia di un Dialogo Mancato e Ritrovato." [Lutherans and Catholics, the Story of a Dialogue that has been Lost and Rediscovered.] Syzetesis V/2 (2018): 227-250.

Clayton, P. A. and M. J. Price. Seven Wonders of the World. Turin: Einaudi, 1989.

Concilio di Trento, Decreto sull'Eucarestia. [Decree on the Eucharist.] Sessione XIII, Capitolo V, Del Culto e della Venerazione Dovuti a Questo Santissimo Sacramento, 11 Ottobre 1551.

Dal Prà, L. (Eds.) I Madruzzo e l'Europa 1539-1658. I Principi Vescovi di Trento tra Papato e Impero. [Madruzzo and Europe 1539-1658. The bishop Princes of Trento between the Papacy and the Empire]. Milan: Charta Editore, 1993.

De Giuliani C. Cristoforo Madruzzo. Giovinezza e Studi, sua Elezione a Principe-Vescovo di Trento e Cardinale. [Cristoforo Madruzzo. Youth and Studies, his Election as Prince-Bishop of Trento and Cardinal.] Archivio Trentino 20 (1905): 52-88.

Del Sole, F. Viaggio nella Meraviglia: Descrivere, Immaginare, Ri-Costruire. [Travel in the Wonder: Describe, Imagine, Re-Build.] Galatina: Congedo, 2019.

Del Sole, F. "The Gift of the Spoken Word: The Word-Image Relationship in the Memory Process." In New Approaches in Contemporary Architecture and Urbanism. Edited by H. A. Nia. Cinius Yayınları: Alanya, 2020, 106-114.

Fabietti, U. "La Costruzione dei Confini in Antropologia. Pratiche e Rappresentazioni." [The Construction of Boundaries in Anthropology. Practices and Representations.] In Confini: Costruzioni, Attraversamenti, Rappresentazioni. Soveria Mannelli: Rubbettino, 2005.

Fagiolo, M. Le Meraviglie e il Meraviglioso. [Wonders and the Wonderful.] Psicon. Rivista Internazionale di Architettura 7, no. III (1976): 3-9.

Falkener, E. Ephesus, and the Temple of Diana. London: Polity Press, 1862.

Ferrario, F. and W. Jourdan. Per Grazia Soltanto. L'Annuncio della Giustificazione. [By Grace Alone. The Announcement of the Justification.] Turin: Claudiana, 2005.

Firpo, M. Dal Sacco di Roma all'Inquisizione. Studi su Juan de Valdés e la Riforma Italiana. [From the Sack of Rome to the Inquisition. Studies on Juan de Valdés and the Italian Reformation.] Turin: Edizioni dell'Orso, 1998.

Firpo, M. Riforma Protestante ed Eresie nell'Italia del Cinquecento. [Protestant Reformation and Heresies in $16^{\text {th }}$ Century Italy.] Rome-Bari: Laterza, 2004.

Galante, P. and J. Miller. The Berlin Wall. New York: Doubleday \& Co, 1965.

Gallino, L. Globalizzazione e Disuguaglianze. [Globalization and Inequality.] Bari: Laterza, 2001.

Giddens, A. Modernity and Self-Identity. London: Polity Press, 1991.

Herle, P. and E. Wegerhoff. Architecture and Identity. Berlin: Lit Verlag, 2009.

Koolhaas, R. The Berlin Wall as Architecture. 'Field Trip', SMLXL, 1995.

La Cecla, F. Mente Locale, per un'Antropologia dell'Abitare. [Local Mind, for an Anthropology of Living.] Milan: Eleuthera, 1993.

La Cecla, F. Il Malinteso: Antropologia dell'Incontro. [The Misunderstanding: Anthropology of the Encounter.] Rome-Bari: Laterza, 2003. 
LiDonnici, L. R. The Images of Artemis Ephesia and Greco-Roman Worship: A Reconsideration. Harvard Theological Review 85, no. 4 (1992): 389-415.

Limentani Virdis, C. "La Decorazione di Castel Velturno: Theatrum Totius Sapientiae." [The Decoration of Castel Velturno: Theatrum Totius Sapientiae.] In I Madruzzo e l'Europa 1539-1658. I principi Vescovi di Trento tra Papato e Impero, 268-277. 1993.

Madonna, M. L. Septem Mundi Miracula come Templi della Virtù. [Septem Mundi Miracula as Temples of Virtue.] Psicon. Rivista Internazionale di Architettura 7, no. III (1976): 25-31.

Magnaghi, A. Il Progetto Locale. Verso la Coscienza di Luogo. [The Local Project. Towards the Consciousness of Place.] Turin: Bollati Berlinghieri, 2010.

Magris, C. "Come i Pesci il Mare." [Like Fish, the Sea.] Frontiere - Nuovi Argomenti 38 (1991).

Major, P. Behind the Berlin Wall: East Germany and the Frontiers of Power. Oxford: Oxford University Press, 2010.

Paba, G. (Ed.) La Città e il Limite. I Confini della Città. [The City and the Limit. The Boundaries of the City]. Florence: La Casa Usher, 1990.

Pliny the Elder. Naturalis Historia. [Natural History.] Pisa: Giardini, 1985.

Prosperi, A. L'Eresia del Libro Grande. Storia di Giorgio Siculo e della sua Setta. [The Story of Giorgio Siculo and his Sect.] Milan: Feltrinelli, 2000.

Rasmo, N. Le Pitture del Castello di Velturno. [Castel Velturno's Paintings.] Alto Adige (1942): 82-100.

Rella, F. Metamorfosi: Immagini del Pensiero. [Metamorphosis: Thought's Images.] Milan: Feltrinelli, 1984.

Remotti, F. Contro l'Identità. [Against Identity.] Bari: Laterza, 1996.

Rocco, G. "Guida alla Lettura degli Ordini Architettonici Antichi. II. Lo Ionico.” [Guide to the Reading of Ancient Architectural Orders. II. The Ionic.] In Guide di Ricerca Storica e Restauro 4, 75-82. Naples: Liguori Editore, 2003.

Rykwert, J. and G. Scattone. L'idea di Città. Antropologia della Forma Urbana nel Mondo Antico. [The Idea of a City. Anthropology of the Urban Form in the Ancient World.] Turin: Einaudi, 1981.

Salvatici, S. (Eds.) Confini: Costruzioni, Attraversamenti, Rappresentazioni. [Boundaries: Constructions, Crossings, Representations.] Soveria Mannelli: Rubbettino, 2005.

Scolari, M. "Principi Compositivi." [Compositional Principles.] Recinti, Rassegna, no. 41 (1979).

Spada, S. I Dipinti di Pietro Maria Bagnatore nel Castello di Velturno. [The Paintings of Pietro Maria Bagnatore in the Castle of Velturno.] In I Madruzzo e l'Europa 15391658. I Principi Vescovi di Trento tra Papato e Impero, 256-267. 1993.

Strabo. Geography. Milan: Rizzoli, 1993.

Subilia, V. La Giustificazione per Fede. [The Justification by Faith.] Brescia: Paideia, 1976.

Theil, S. Castel Velturno. Bolzano: Athesia Editore, 1984.

Varzi, A. C. "Teoria e Pratica dei Confini." [Boundary Theory and Practice.] Sistemi Intelligenti 17, no. 3 (2005): 399-418.

Ward, J. Post-Wall Berlin: Borders, Space and Identity. London: Palgrave Macmillan, 2011.

Wolfsgruber, K. Castel Velturno: Costruzione e Decorazione. [Castel Velturno: Construction and Decoration.] Bolzano: Soprintendenza Provinciale ai Beni Culturali, 1995.

Zanini, P. Significati del Confine. I Limiti Naturali, Storici, Mentali. [Meanings of the Border. Natural, Historical, Mental Limits.] Milano: Mondadori, 1997. 


\title{
Holistic Approach in Recovery and Conservation of Modern Architecture as Sign of Historical Identity
}

\author{
By Pasquale Cucco ${ }^{*} \&$ Agustin Mariano Santoro ${ }^{ \pm}$
}

\begin{abstract}
In $20^{\text {th }}$ century a new ideological paradigm emerged in architecture, leading to mutations of function, form and technology, and marking a break with the traditional configuration of spaces, compositional and aesthetic forms. This trend has imposed an architecture based on simple and functional shapes and industrial materials, without excessive ornamentation. Through some selection criteria it is possible to recognize in the modern production "signs and meanings" of historical-documentary value, to be preserved and protected. Currently, there is a lack of consensus in local and national regulations on the criteria to be used for the selection of works to be recovered rather than demolished, on the materials and construction techniques or about the interventions on the Modern Movement architecture, often guided only by economic criteria. The main challenge is how to recover the existing heritage and adapt it to the necessary conditions of habitability, functionality and sustainability of the XXI century, without breaking with its own identity characterized by rationalism, functionalism and industrialized technology. Through a case study in Argentina, this research intends to propose a methodology for the selection of modern works in order to apply recovery and conservation interventions and to guide any projects according to a holistic approach.
\end{abstract}

\section{Introduction}

The architectural production of the last hundred years connotes a large part of territories and cities all over the world that, when inspired by artistic, architectural and handicraft ideals, represents an exclusive set of ways of planning, building and using contemporary resources. Many works lie in an advanced state of decay, due to poor cultural recognition by professionals and community and to lack of conservation and maintenance interventions. ${ }^{1}$ By considering the three aspects of architectural work - conservation, transformation, maintenance - in a single methodological unicum allows to pursue the best choice, not harmful to the artefacts but necessary to improve their life and performance, in accordance with current principles of sustainability. However, if these aspects seem to be simple solutions for new buildings, they are more complex for existing heritage.

The search for sustainability means appealing to "govern" the intervention, according to the uniqueness of each building and 1) in the protection of its historical, cultural and social characteristics; 2) in the ability to ensure flexibility

\footnotetext{
"PhD Candidate, Department of Civil Engineering, University of Salerno, Italy.

${ }^{ \pm}$Building Engineer and Architect, Faculty of Architecture, Urbanism and Design, National University of Cordoba, Argentina.

1. See J. Cerverathe, "Decline of Modernist Architecture: Deterioration, Obsolescence and Ruins," Palapa. Revista de Investigación Científica en Arquitectura IV (2009): 29-43.
} 
for reuse; 3) in the choice of compatible, reversible and distinguishable solutions; 4) in maximizing the exploitation of the building's intrinsic resource; 5) in organizing an interdisciplinary and well-form operating group; 6) in rationalizing the organization of construction site to facilitate the activities and support their safety. $^{2}$ It useful to remember that preservation, protection and enhancement of cultural heritage, both ancient and modern, is one of Sustainable Goals (11. Sustainable cities and communities, target 11.4 "Strengthen efforts to protect and safeguard the world's cultural and natural heritage").

Regarding modern architecture, simple solutions cannot be implemented, but the formal and technological peculiarities require more comprehensive reflections that can bring the practice back to the methodological rigor typical of the restoration discipline. Often, in fact, it is common to believe that the examples of the $20^{\text {th }}$ century production, due to their more modern and industrial character, require easier solutions and, above all, reproducibility and maintenance operations in series, not considering the feature of craftsmanship, the innovative aspects generated by the Modern Movement and, even, the affection of local communities. ${ }^{3}$

\section{Research Aim}

The holism assumes that all the properties of a system cannot be determined or explained as a sum of its components ${ }^{4}$ but all the constituent parts must be correlated with each other, in order to cover any aspect involved. Therefore, it is necessary to understand this complexity and work on each one of the parameters considering the repercussions as a whole.

An architectural project must be at least divided into four main interrelated issues: Society, Architectural Design, Structure, Sustainability.

Society: history, evolution, social and cultural context, demography, popular feeling, integration with industry and commerce, urban and social quality. This stage is useful to maximize the potential of cultural heritage, to serve as a driver for economic, social and environmental regeneration, by minimizing damaging consequences of unnecessary expenditure. An architecture that does not respond to the needs of people, both in terms of functions and design, can cause its deterioration and rejection, generating unexpected changes in its own development. $^{5}$

2. See L. Kealy and S. F. Musso (Eds.), Conservation/Transformation, Transactions on Architectural Education (Leuven: EAAE, 2011).

3. See E. Garda, "Gli Edifici del Movimento Moderno. Caratteristiche Costruttive e Compositive," in Manuale del Recupero Edilizio. Edifici in Muratura e in Cemento Armato, 134139. Edited by F. Astrua and R. Nelva. Santarcangelo di Romagna (RN): Maggioli Editore, 2017.

4. See N. Portugali, The Act of Creation and the Spirit of a Place: A HolisticPhenomenological Approach to Architecture (Fellbach: Edition Axel Menges, 2006); D. Rodwell, The Achievement of Exemplary Practice in the Protection of our Built Heritage: The Need for a Holistic Conservation and Sustainability. Orientated Vision and Framework (Bucharest: UNESCO, Management of Private Property in the Historic City-Centres of the European Cities-in-Transition, Proceedings of UNESCO International Seminar, 2001), 127-153.

5. Regarding the role of society in the architectural project see P. Jenkins and L. Forsyth, Architecture, Participation and Society (New York: Routledge, 2010); J. Albrecht, "Towards a 
Architectural Design: artistic act that reflects the language and style of a such period in a specific geographical context; the way in which space and functions are articulated. Through the project, the conservation and maintenance operations are carried out. ${ }^{6}$

Structure: material process, technologies, construction methods, construction site management.

Sustainability: ability to express concisely and persuasively the connections between the built heritage conservation and the wider national and international agendas of sustainability. Environmental protection measures as well as economic and social reflections are included. ${ }^{7}$

The purpose of this contribution is to provide a methodological approach in defining projects for recovery, reuse and restoration of Twentieth century heritage, according to the holistic approach, here applied to a case study.

The method allows to discern the buildings to be recovered on the basis of clear signs of cultural and construction seasons that testify community's affection towards them.

It is surely not possible to pay the same attention to all the modern buildings, but a primary choice is needed starting from a "value judgment" that allows to draw up the map of those constructions that need restorative and conservative care to pass them to future generations.

\section{Recovery and Restoration of Modern Architecture}

Recovery in architecture is a set of interventions in which transformations and conservation are integrated as much as possible, by taking into account both material, physical and intangible aspects such as significance and historic evolution. ${ }^{8}$ This activity requires an interdisciplinary approach that includes urban planners, restorers and architects, but also structural engineers, plant engineers, geologists, historians, etc. There is no parameter that is not related to each other, like a chain in which each link is fundamental in the success of the final work.

However, the concept of modern architecture assumes a "quality judgment", excluding all the architectural products made in the Twentieth century built only as a response to market or to industrial needs.

Thus, it is important to face these moral dilemmas and solve technical and cultural problems when it is necessary to preserve recent cultural heritage, in the awareness that every choice must be calibrated in its own space-time

Theory of Participation in Architecture. An Examination of Humanistic Planning Theories," Journal of Architectural Education 42, no. 1 (1988): 24-31.

6. See G. Shankland, "Conservation through Planning," in Conservation and Development in Historic Towns and Cities, 73-82. Edited by P. Ward. Oxford: Oriel Press, 1968.

7. See D. Barthel-Bouchier, Cultural Heritage and the Challenge of Sustainability (New York: Routledge, 2013).

8. See K. Powell, Architecture Reborn. Converting Old Buildings for New Uses (New York: Rizzoli International Publications Inc., 1999). 
circumstances. $^{9}$ At the same time, a more complete historical study is needed, beyond criticisms and censures, due to the unfortunate coincidence of this heritage, especially in Europe, with dictatorial regimes and because of its link with economic and land speculations.

In a first schematization, there are four open issues:

1. Selection. In the impossibility of preserving the whole built environment, it is necessary to identify a map of the artefacts to be preserved and recovered, which show the features of testimony of passing time. This screening phase must be conducted in light of specific historical and geographical contexts (Table 1).

2. Aim. It is difficult to suppose a purely aesthetic purpose, as a "museumization" of modern works. The goals can be many: i.e., functional, technological, structural recovery, adaptation or improvement by virtue of legislative provisions, restoration of surfaces or finishing works, materials, etc. In accordance with the aim, the related methodological and operational phases are defined.

3. Technical difficulties. Traditional construction methods suffered a rift, in the late Nineteenth century, with the introduction of new materials and techniques that encouraged the prefabrication and the almost exclusive use of steel and reinforced concrete, replacing the traditional construction with its artisan practice, materials and rule of art. Concrete, first considered eternal, is characterized by particularly delicate internal balance mechanisms and it is influenced by the surrounding conditions (fire, shocks, sea water, physical corrosion, chemical attack, air humidity, temperature, design errors, incorrect concrete production, mix design, etc.)

4. Method. Currently the needle oscillates between the rigor of pure conservation and the creativity of a "contemporary redesign". Appropriate methods need to be defined in relation to each problem after a careful analysis phase (Table 2).

9. See S. Macdonald, "Reconciling Authenticity and Repair in the Conservation of Modem Architecture," Journal of Architectural Conservation, no. (1996): 36-54. 
Table 1. Fundamental Criteria in Selection of Modern Works

\begin{tabular}{|l|l|}
\hline Main Criteria & \multicolumn{1}{c|}{ Description } \\
\hline $\begin{array}{l}\text { Criterion 1: Creative work of } \\
\text { human genius }\end{array}$ & $\begin{array}{l}\text { The modern works were designed and built by engineers } \\
\text { and architects who determined the development of the } \\
\text { construction practice of the Twentieth century. In this } \\
\text { way, architectural complexes should be considered not } \\
\text { only celebratory of their design and technique but also of } \\
\text { those who conceived them. }\end{array}$ \\
\hline $\begin{array}{l}\text { Criterion 2: Influence of innovative } \\
\text { technologies }\end{array}$ & $\begin{array}{l}\text { The development of technology plays a fundamental role } \\
\text { in the selection process in terms of architectural solutions, } \\
\text { construction methods, experimental materials, etc. Modern } \\
\text { historiography of technology requires an interdisciplinary } \\
\text { (social, economic, environmental and political) approach } \\
\text { capable of investigating the development of buildings. }\end{array}$ \\
\hline $\begin{array}{l}\text { Criterion 3: Exceptional example } \\
\text { impressed in the memory of the } \\
\text { community }\end{array}$ & $\begin{array}{l}\text { Many buildings reach exceptional levels both for their } \\
\text { ingenious construction and for their ability to survive over } \\
\text { time. Originality and authenticity, typicality and } \\
\text { exceptionality, historical integrity and affection of the } \\
\text { community in figurative or functional terms, are some of } \\
\text { the aspects that converge in the selection process. }\end{array}$ \\
\hline $\begin{array}{l}\text { Criterion 4: Illustrative example of } \\
\text { economic or social developments }\end{array}$ & $\begin{array}{l}\text { Modern architecture has been a driving force of political, } \\
\text { social, economic and cultural development of each } \\
\text { country, satisfying people's desires to live in new, } \\
\text { performing and aesthetically satisfying contexts, thus } \\
\text { providing a valuable social and economic contribution to } \\
\text { the development of society and city. }\end{array}$ \\
\hline
\end{tabular}

Restoration of modern buildings, chosen according to the main criteria (Table 1 ), is recognized as a real restoration work, whose methodological approach is supported by the founding principles of the discipline, beyond obvious differences and still open challenges: ${ }^{10}$ reversibility and recognisability are essential and mandatory, contemporary architecture must follow the recommendations of restoration valid when the intervention takes place; distinguishability of intervention seems more emphasized in the projects on ancient works; reuse of modern works and their adaptation to contemporary requirements seem more easily by virtue of their planimetric and structural conformation. ${ }^{11}$ This caused incongruous transformations and the use of incorrect and incompatible materials.

Therefore, preserving the modern production implies understanding its specific values, with the identification of the mechanisms and criteria that ruled its construction, transformation and use overtime. ${ }^{12}$

This topic forces us to deal with the founding aspects of contemporary civilization, with the new meanings assumed by the buildings in relation to deep

10. See R. Paschoalin and M. T. Barbosa, "Restoration of the cathedral of Brasilia: Challenges and Conflicts of Restoration of Modern Architecture," Conservar Património 18 (2013): 45-53.

11. See R. Sanders, B. Shepherd, E. Skowronek and A. Hoffmann, "Sustainable Restoration of Yale University's Art + Architecture Building," Association for Preservation Technology International Bulletin 42, no. 2/3, Special Issue on Modern Heritage (2011): 29-35.

12. See M. G. Picchione, "La Tutela delle Opere di Architettura Contemporanea," L'Architetto Italiano, no. 4 (2004). 
Vol. 7, No. $4 \quad$ Cucco \& Santoro: Holistic Approach in Recovery and Conservation...

social, cultural, technological and economic transformations. ${ }^{13}$ Technological innovations as well as the link between form and structure and the standardization processes or experiments are key issues useful to investigate this theme, understand innovative contents and propose virtuous solutions, overcoming speedy operations of demolition or replacement.

Table 2. Diagram relating to the Methodological Approach of Analysis, Recovery

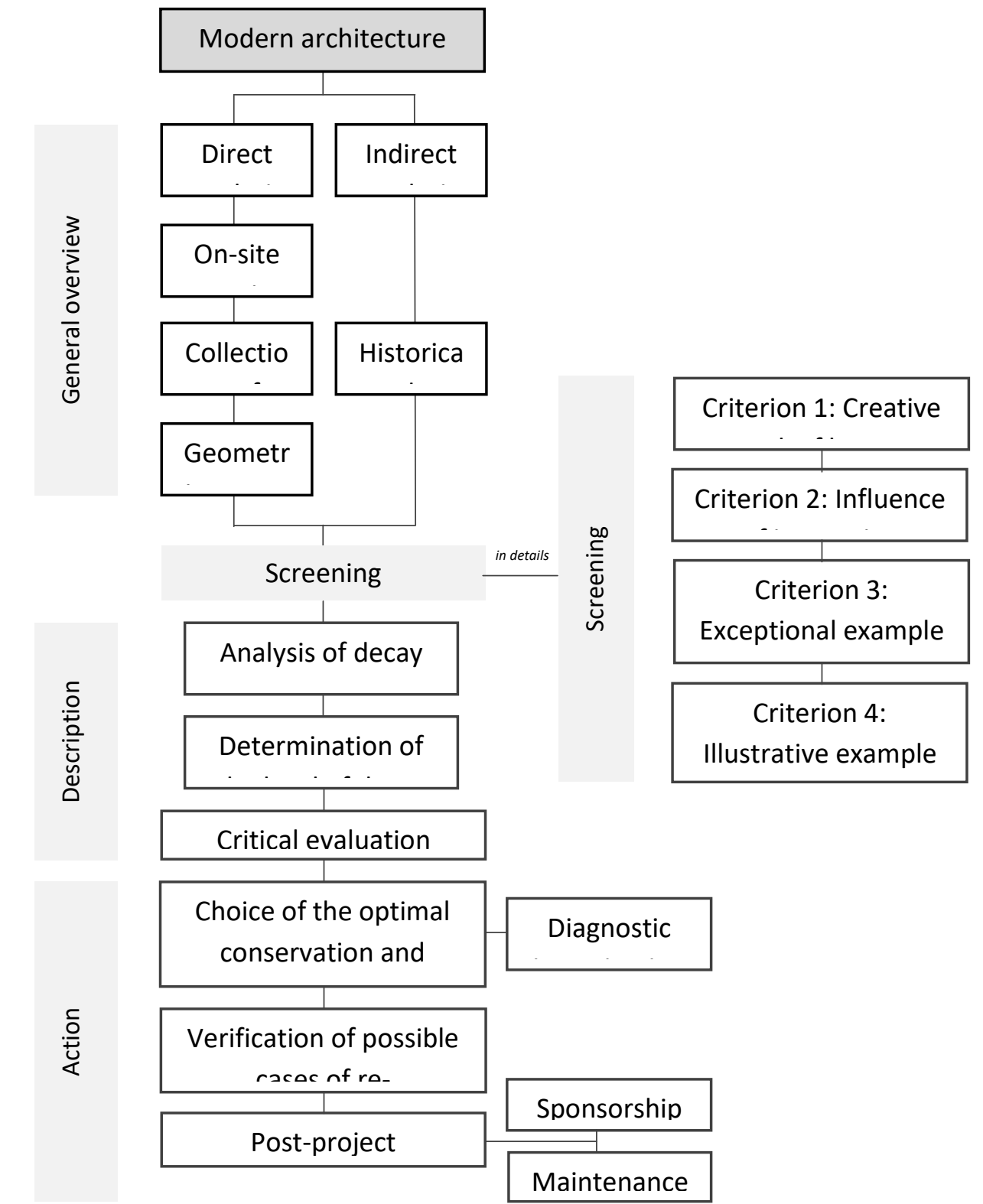

and Restoration of Modern Architecture

13. See M. A. Crippa, "Per il Restauro del Moderno. Qualche Riflessione sul Riconoscimento e il Progetto di Restauro di Architettura del Novecento," Territorio Nuova Serie, no. 26 (2003). 


\section{Application in San Martin de los Andes, Argentina}

The research on which this article is based is applied to the building known as the former "Hotel Sol de los Andes", located in the city of San Martin de los Andes, in the south of the province of Neuquén, in Argentina (Figure 1).

The main criteria in Table 1 are used to validate the choice to recover, conserve and return to the community this kind of construction.
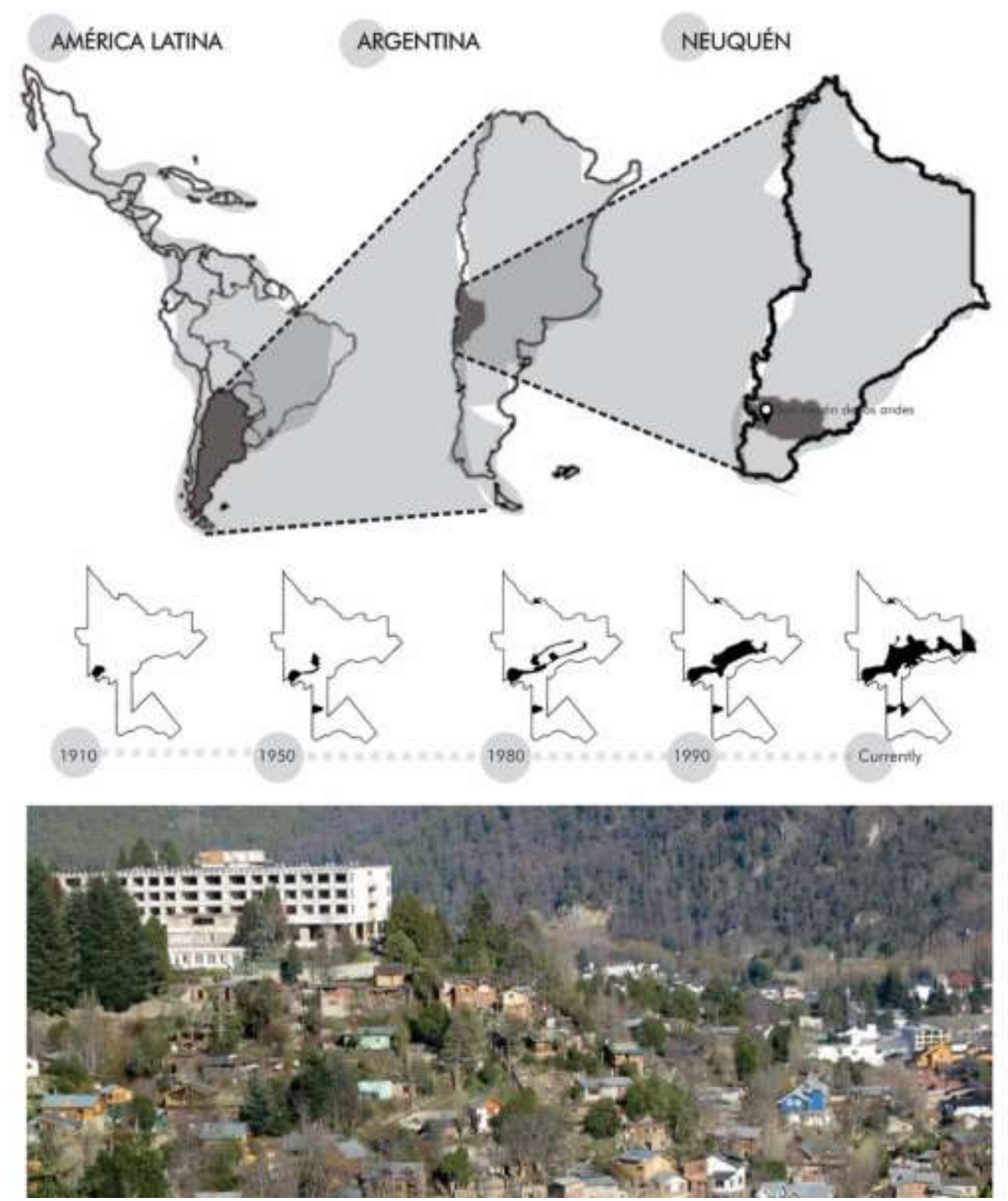

Figure 1. Geographical Location of San Martín de los Andes and its Evolution over Time

Source: Drawings by Authors. 


\section{Criterion 1: Creative Work of Human Genius}

Built in 1974 during the tourist development, the construction was a 5-stars hotel, with services, green spaces and recreation areas. The paradigm of 1980s Argentinean tourism was characterized by attracting tourists with greater purchasing power through luxury constructions that solved all their needs in just one place. At the beginning, the hotel had 72 rooms, 19 suites and apartments, with private bathroom, restaurant, lounge, solarium, swimming pool, cafeteria, bar, shopping mall, conference room and casino (Figure 2).
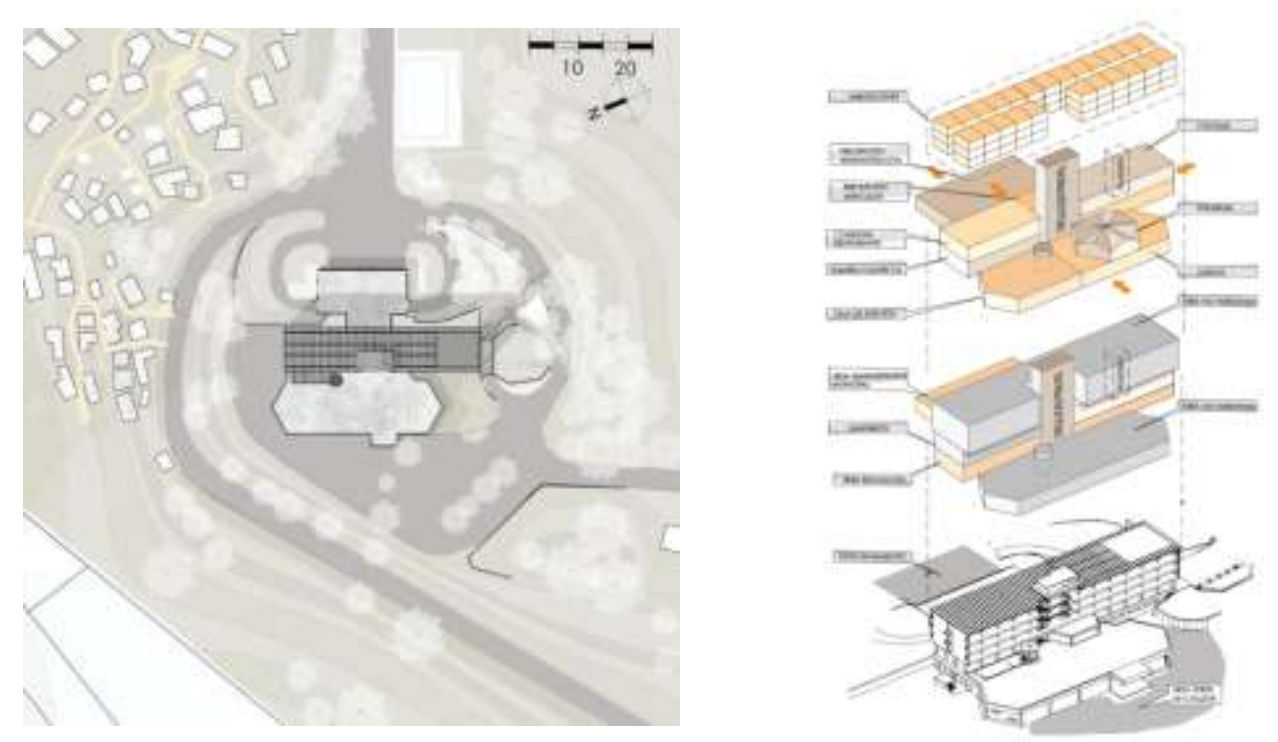

Figure 2. Current State of the Hotel before Renewal Project

Source: Drawings by Authors.

This building consisted of three big blocks of reinforced concrete. It was inserted in the middle of the mountain, joining with the existing topography, by generating several terraces that allow to appreciate all the beautiful views, above the high vegetation.

The hotel was built with the clear intention of highlighting and showing its luxury and, due to its size, it broke through the surrounding natural landscape, rising above the city (Figure 3).

In 2002 the municipality of San Martin, as a precautionary measure to resolve a confused network of commercial and tourist licenses, decided to close the hotel, by turning it into a province's property, so that any new decision had to be approved by the provincial government. In 2005 a private investor presented a project to restore the old structure, turning it into school and hotel. The walls and the floors were demolished, the furniture was removed. During the renovation, new external insertions were built, and some small structural reforms were made. After these works, never completed, the work was interrupted and the project was completely abandoned, with greater deterioration (Figure 4). 


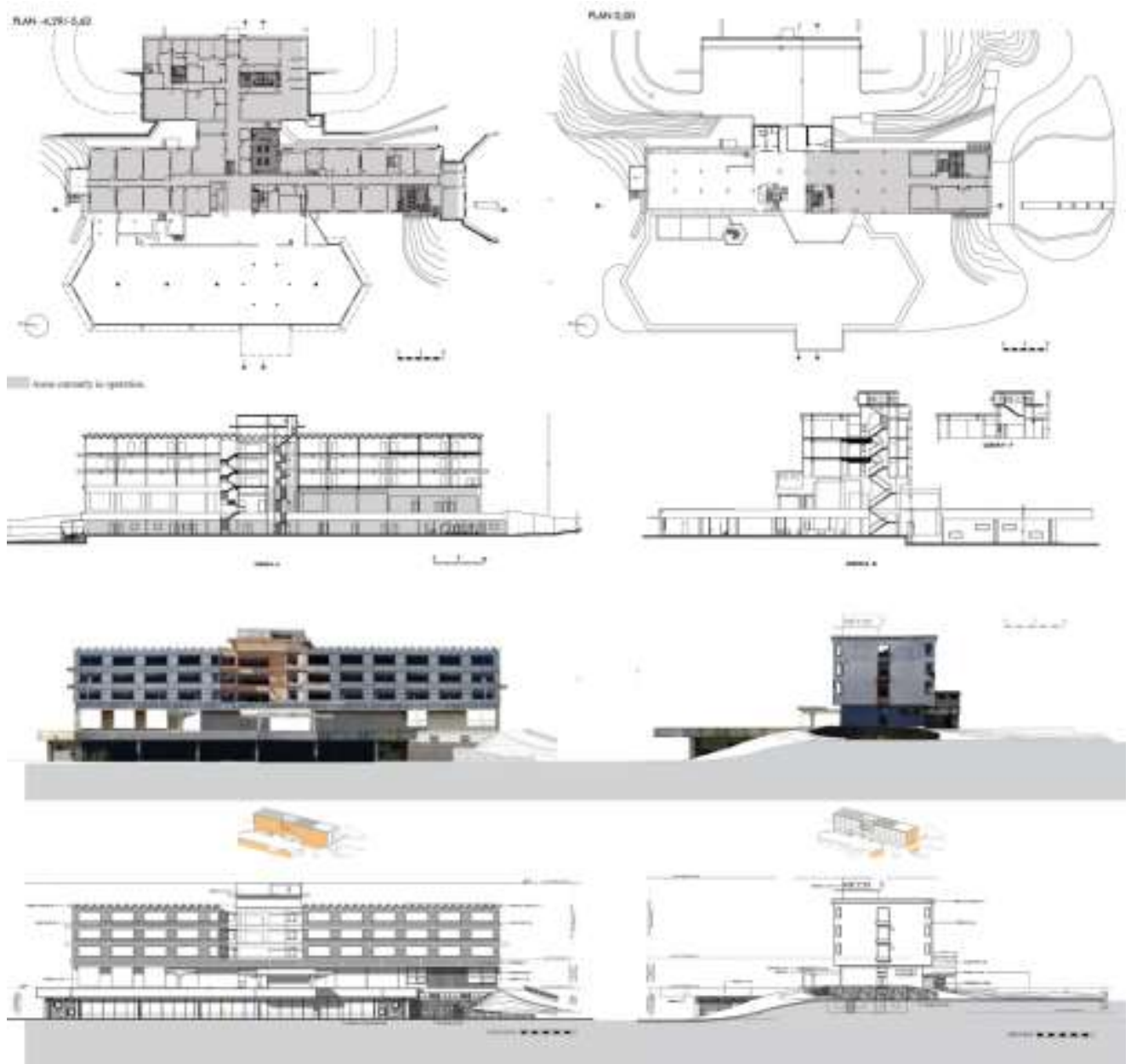

Figure 3. Plans, Sections and Elevations before Renewal Project

Source: Drawings by Authors.

In 2013, some activities of both Escuela del Sol and University of Avellaneda were allocated. About $1,200 \mathrm{~m}^{2}$ were renovated, with new classrooms and spaces, modifying the original layout.

The paradigm started to change, from a touristic construction to one that produces knowledge by spreading education and culture within the city and for its inhabitants.

Criterion 2: Influence of Innovative Technologies

This construction was considered a landmark within the city, traditionally characterized by low-rise buildings, in wood, stone and brick walls. The hotel was the first building with a new language, with its concrete structure and its large size in the middle of the mountain. After its construction and due to the great criticisms received by the inhabitants, the municipality decided to propose clear rules for new constructions, thus avoiding the loss of mountain traditional image. These regulations established mandatory percentages of any materials, including wood and stone, and the maximum heights of buildings, which could not exceed 3 
levels. Over the years, however, the hotel has become an iconic element easily recognizable, a real reference point for visitors and residents.

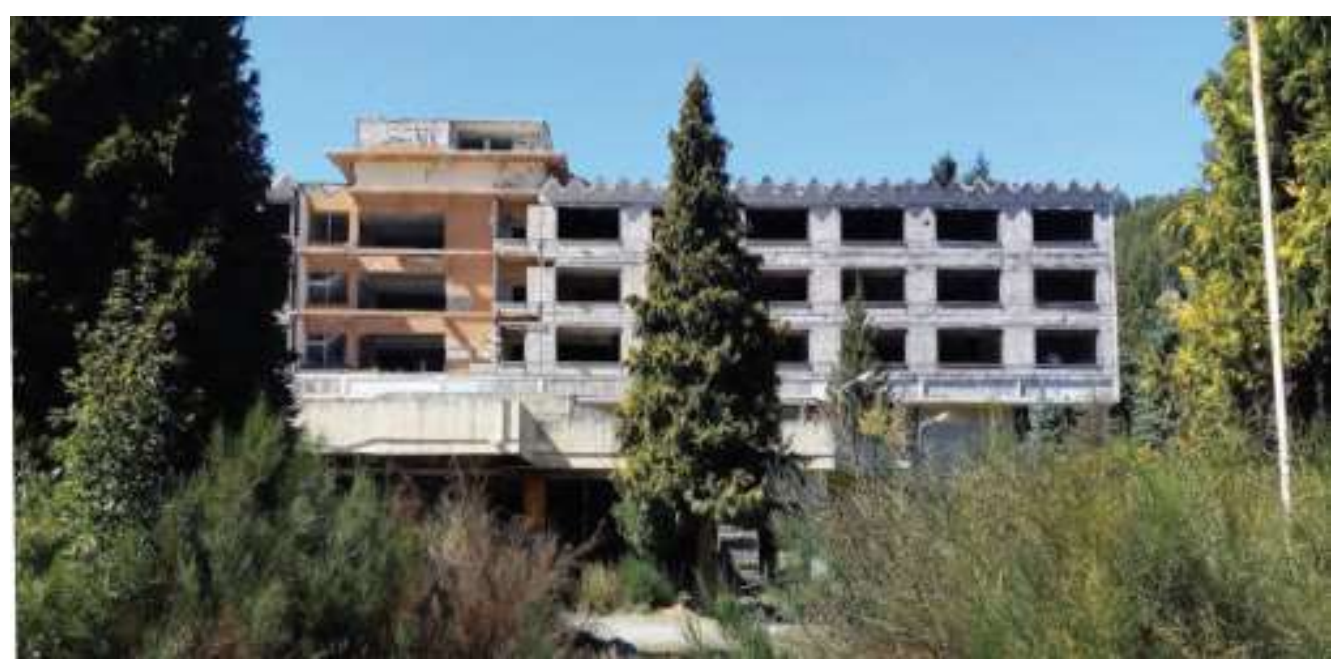

Figure 4. Current State of the Building (Photo by Authors)

Criterion 3: Exceptional Example Impressed in People Historical Memory

There were so many years in which the building was abandoned that few remember it in its magnificent moment. Today it is a product of the various transformations undergone over time.

However, for a long time it was not accepted by the community for its "break" with the surrounding landscape, but soon it became a city symbol impressed in the memory of citizens, almost a giant watching over the territory from above. Today the current face is well impressed in the urban landscape. By viewing the mountain and seeing how this large building stands among the vegetation, Hotel Sol de los Andes is a singular and representative element of a whole town.

\section{Criterion 4: Illustrative Example of Economic or Social Developments}

The hotel meant a big change: before its construction, there were no hotels of this size within the city. The hotel opened soon its doors as a national ski centre and an airport had to be built to accommodate tourists from all over the country. Many tourists, after their trip, decided to stay permanently in San Martin in search for peace and to escape from the metropolitan life. San Martin, therefore, has been positioned as one of the main cities nationwide, chosen by tourists, due to the Chapelco ski centre and the various activities offered thanks to its proximity to naturalistic ecosystems.

Today, a part of the functions of the Municipality are located on the ground floor with an occupation of $1,337.63 \mathrm{~m}^{2}$, which corresponds to only $25 \%$ of the whole area. The upper floors aren't working because of their structural safety cannot be guaranteed. 


\section{Renewal Project}

In accordance with the concept of holism in architecture, the proposed project is structured in 4 key interrelated points.

\section{Society}

San Martin de los Andes is characterized by the mixture between urbanized areas and nature, with a "main urban plant" corresponding with the historical centre, and many peripheral expansions. In 2018, San Martín de los Andes 2030 Strategic Plan began to operate with the aim of establishing clear policies for a sustainable development integrated with the strategic guidelines of the Province of Neuquén. The purposes of this plan are carried out through 16 strategic projects, including the creation of a new hospital, a recycling plant, a conference centre, a linear park, distributed within the city.

The site belongs to different entities, which are geographically linked in this area of intervention; both municipality, National Park and the Mapuche community have jurisdiction over this sector, with some conflicts between them. So, any new use must contemplate all these actors, by generating a construction with social equity. Close to the property there is Canteras district inhabited by 230 families and almost 700 residents.

In order to choose the new uses, an online survey was carried out to know the people opinion, by Google forms platform, easy to answer, with multiple choice and other sections to develop their answers and opinions. It was disseminated to the community, through the implementation of social networks shared by the official accounts of San Martin de los Andes. There were a total of 408 responses from people of different ages, social classes, cultural backgrounds and different professionals. Three main criteria were evaluated: Knowledge, accessibility and uses (Knowledge, level of information about the current state of building and site; accessibility, simplicity in accessing the site; new uses considered most relevant for the building. After elaborating the different answers, the decision was to generate a mixed program (Figure 5).

The building incorporates a civic centre to develop and promote local culture, university and cultural space. The pyramid of the local population shows a decrease in young people (18-35 years), who leave small towns to move towards more important cities with the ambition of obtaining a university degree. The new function has been validated in accordance with the check list for verifying the compatibility of new uses in existing buildings. The new intended use reaches the value of $18.5 / 23$ points: very satisfactory (Figure 6). 


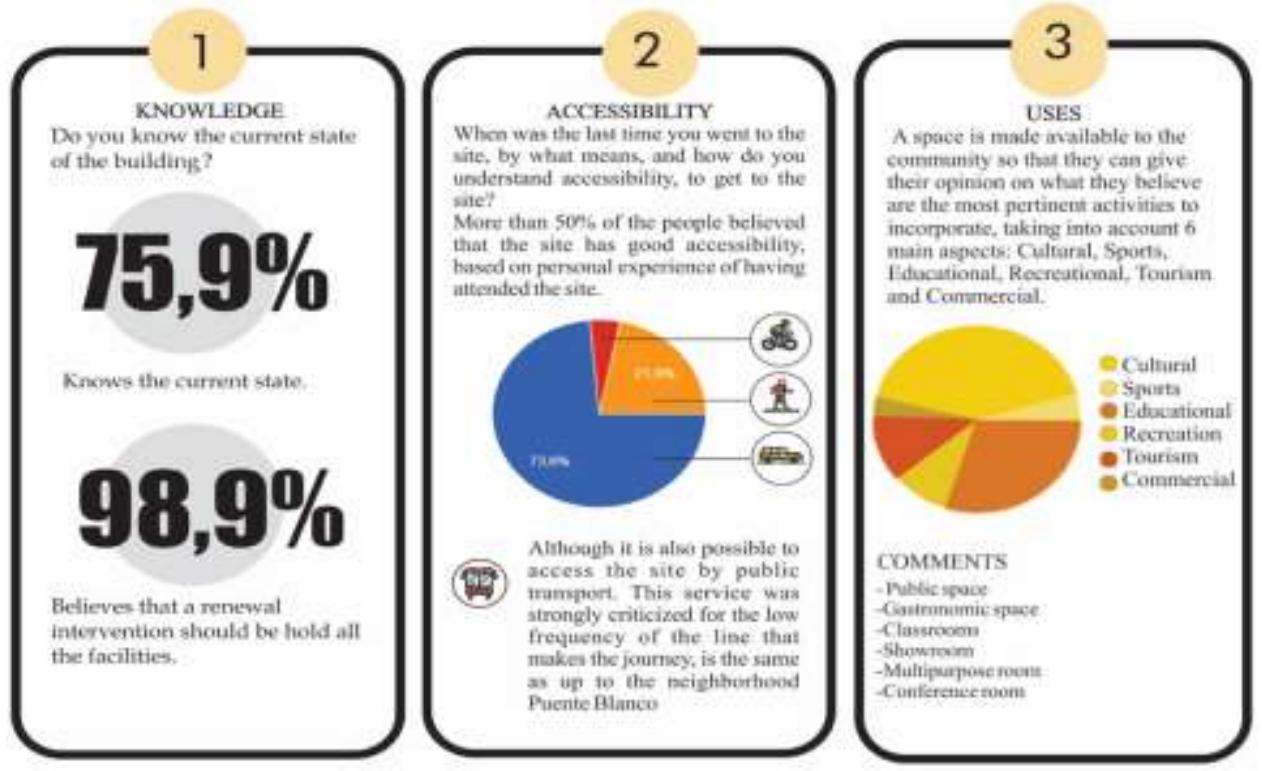

Figure 5. Summary Table of the Web Questionnaire Made to the Community

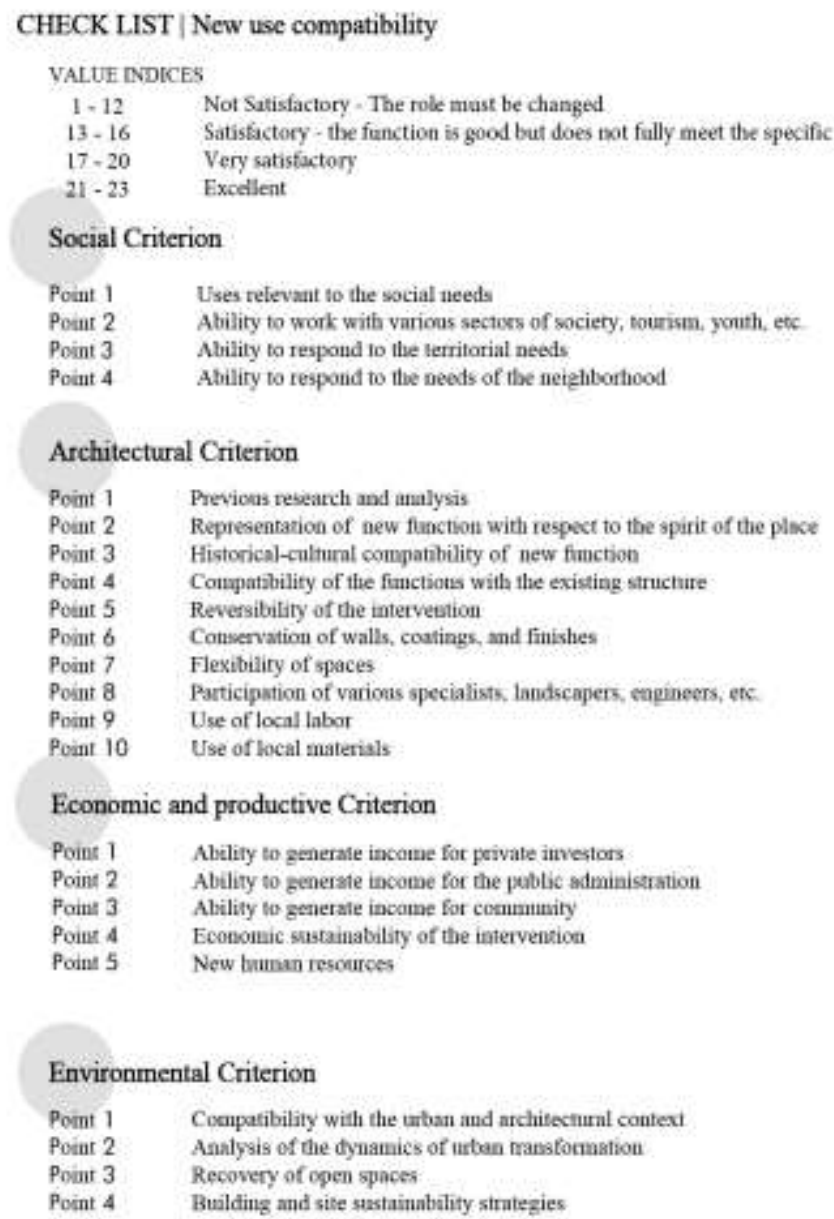

Architectural Criterion

Point 1 Previogs pebianch and analysis

Convenation of walls, coatings, and finishes

Point 7 Flexiblitity of spaces

Participation of vanous specialists, landscapers, eapineers, efc

Economic and productive Criterion

\begin{tabular}{|c|c|}
\hline \multirow{2}{*}{\multicolumn{2}{|c|}{ 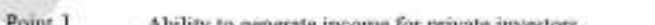 }} \\
\hline & Ability to generafe incaune for peivate investors \\
\hline Point 2 & Ability to penerste income for the poblic administration \\
\hline Point 3 & Ability to generate incame for cormmunity \\
\hline Point 4 & Economic sustainability of the intervention \\
\hline Point 5 & New buman resources \\
\hline \multicolumn{2}{|c|}{ Environmental Criterion } \\
\hline Poimt 1 & Cocmpatibility with the urban and architecturnal context. \\
\hline Point 2 & Asalysis of the dynamics of urtan mansformation \\
\hline Point 3 & Recovery of open spaces \\
\hline Point 4 & Building and site sustainabihity strategies \\
\hline
\end{tabular}

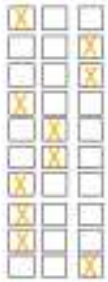

Figure 6. Check List Useful to Verify the New Use Compatibility 


\section{Architectural Design}

The organization within the building was stratified in different levels. The civic centre is located on the ground floor, divided into 3 volumes: the first, corresponding to the access, houses a gastronomical area and it is complemented by a covered plaza for various outdoor activities; the second includes both the administrative area and the art and music rooms that have special requirements; the third contains all the activities that require movement, such as dance, theatre, body expression, etc. It also incorporates an auditorium for 200 people in which the stage can be used both indoors and outdoors. The media library is located on the first floor, as a link between the civic centre and the university sector. The following floors houses the university spaces (Figure 7).
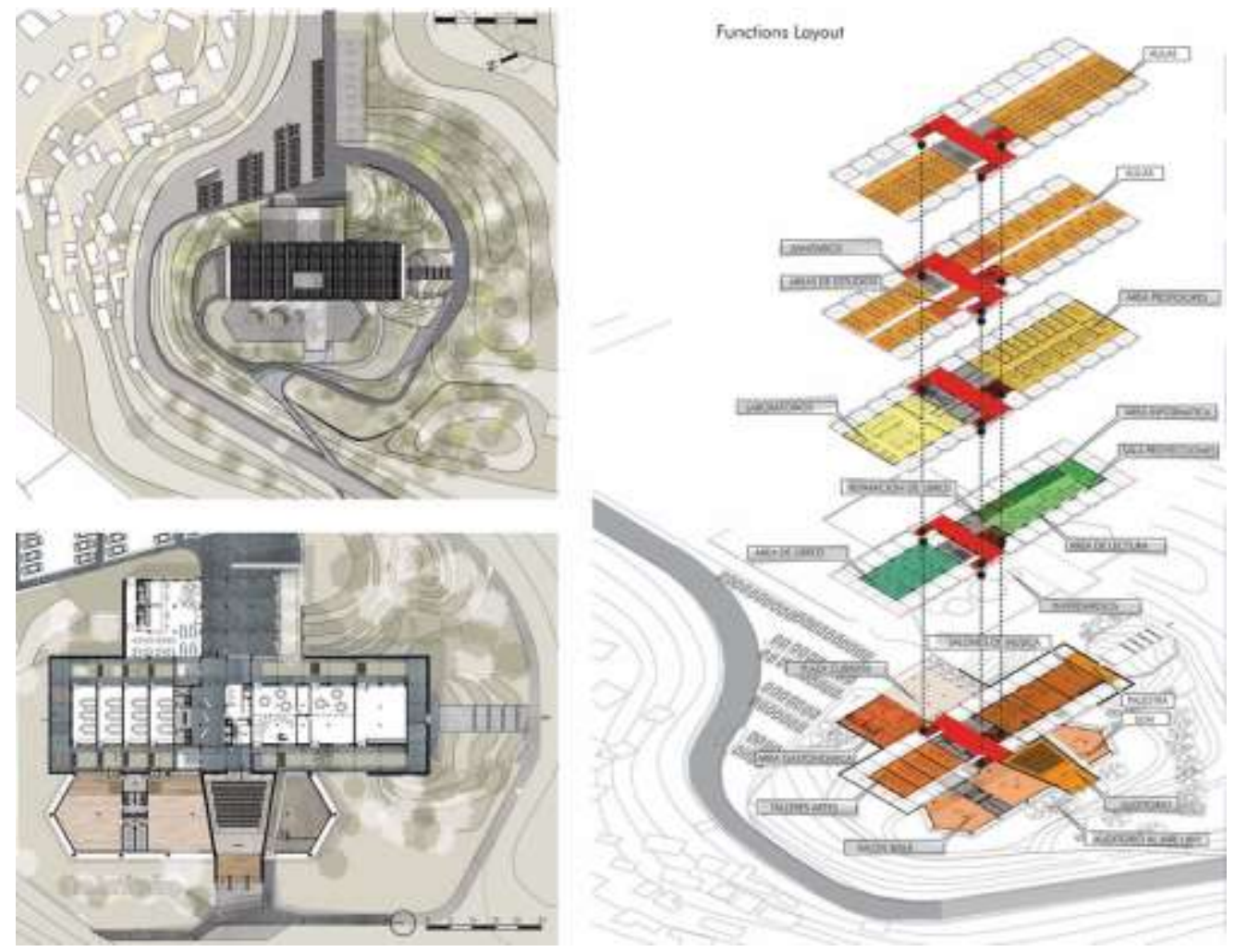

Figure 7. General View, Ground Floor and Functions Layouts after Renewal Project

Source: Drawings by Authors.

A new structure is integrated into the architectural design. This new structure allows to generate transition spaces between the different volumes, incorporating a spatial aggregate, which allows the subdivision of the different functions and the horizontal and vertical circulation of users (Figure 8).

Structure and architecture merge to form a new language, generating a new imprint in the landscape. Using the modulation of the previously designed structure and taking into account the local solar map, we found an average angle of 52 degrees that allowed us to work on a surface that lets to filter the direct radiation of 
the sun during the summer season and exploit it in winter. The $100 \%$ recyclable textile technology allows to dissipate up to $95 \%$ of the heat in summer, saving up to $50 \%$ in cooling costs. The contemporary language does not disguise itself in the context but stands out as well as the original building. The white finish allows it to be used as a screen on holidays (Figure 9).

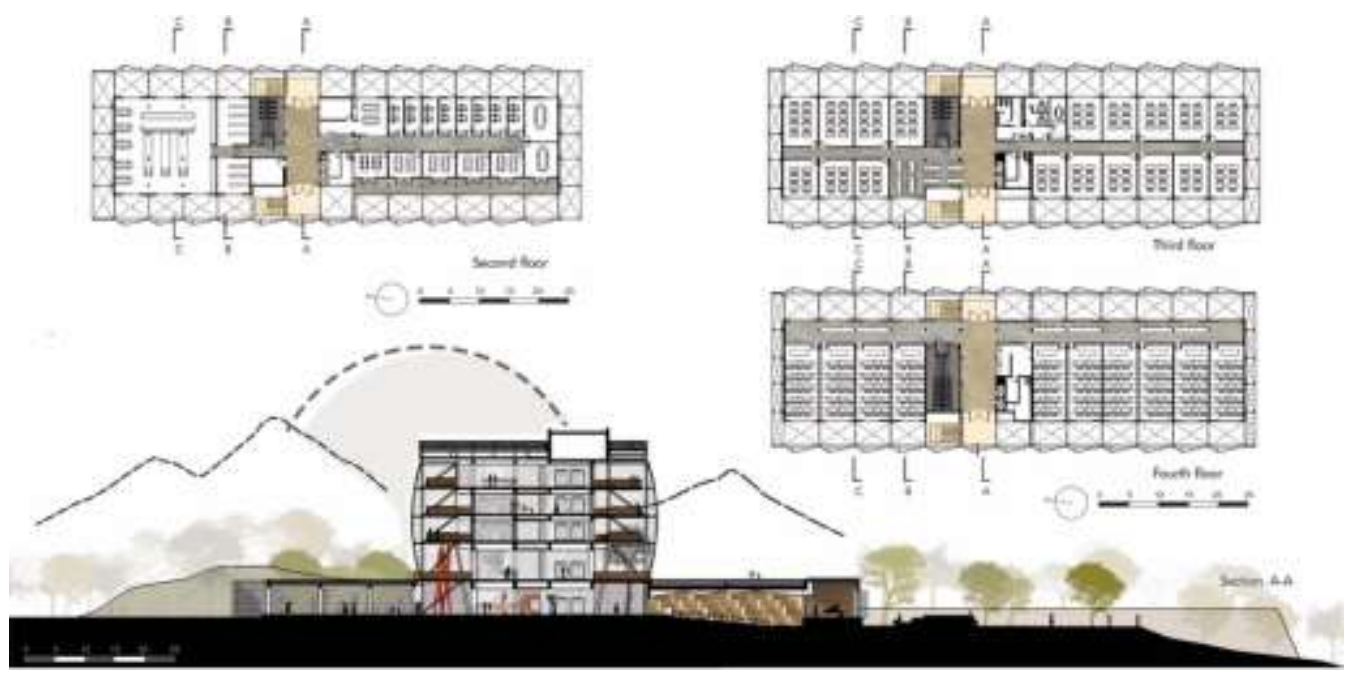

Figure 8. Project Plans (Second, Third and Fourth Floors) and Sections Source: Drawings by Authors.
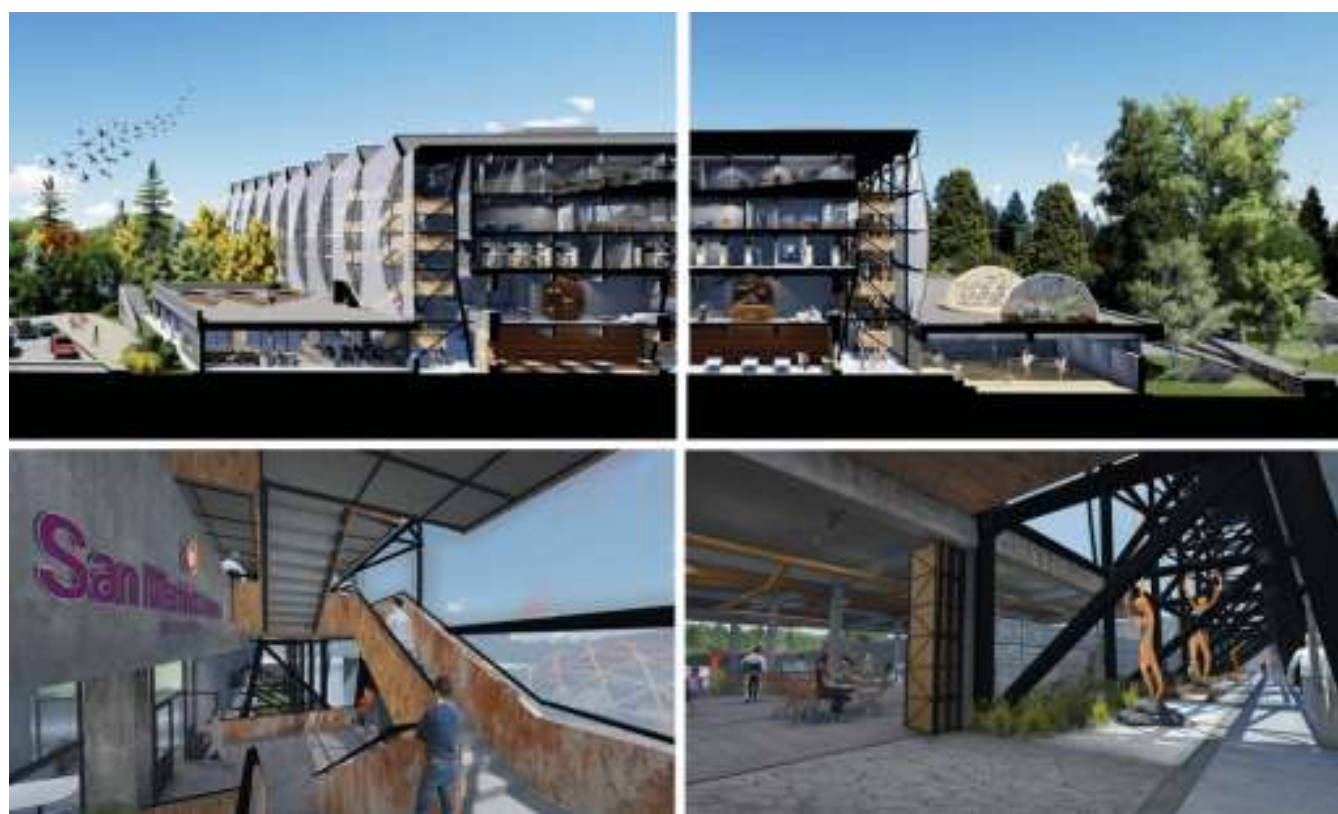

Figure 9. Project Exterior and Interior Renders

Source: Drawings by A. M. Santoro.

Structure

In July 2015, the Municipality of San Martín de los Andes commissioned a technical report to evaluate the current state of the structure. Non-destructive tests 
were carried out to determine the quality of the concrete, the quantity of steel and the arrangement of the reinforcements of the resistant elements. This information was the basis for this work. ${ }^{14}$

The structure is mainly composed of three volumes, two with only one level and the third with five levels. Due to its characteristics, the highest building is the most structurally compromised especially for its poor performance to the seismic forces. Therefore, it was decided to base the study on this portion. The resistant structure is made up of columns, beams and solid slabs. The upper rectangular part is divided into three blocks separated by expansion joints. The columns and beams form porticoes in both directions with variable height sections.

It was performed a pushover analysis, i.e., a non-linear method. In general, the structure capacity depends on the strength and deformation capacity of each of its individual components. In order to determine the capacities after the elastic limit, non-linear analysis procedures are necessary. This process was carried out by the software SeismoBuild, able to predict the displacement behaviour of spatial frames under static or dynamic loads.

In conclusion, the torsional stresses presented in the elements are not very large, helped by the plan regularity and to the disposition of its structural elements. The structure is capable of supporting gravitational loads, but it cannot resist seismic loads.

It is proposed to generate a metal great rigidity exoskeleton to absorb the seismic loads avoiding reinforcing all the connections. The structure, integrated into the architectural design, solves not only the structural resistance but also environmental and functional comfort issues (Figure 10).

The methodology to carry out this seismic study is a theoretical method that considers the seismic loads as unidirectional, taking into account the two directions of analysis to find the necessary stiffness, simplifying the calculation method. It is important to consider the connection between the two configurations: the existing reinforced concrete structure and the new steel structure. It is possible to work with a rigid horizontal plane, which guarantees the uniformity of the loads. This plane was generated thanks to the implementation of a horizontal beam that will be mounted under the existing ones.

14. Only a small part the structural analyses is reported here. They were conducted under the supervision of Professor Gianvittorio Rizzano and Engineer Massimo Latour, Department of Civil Engineering, University of Salerno. 

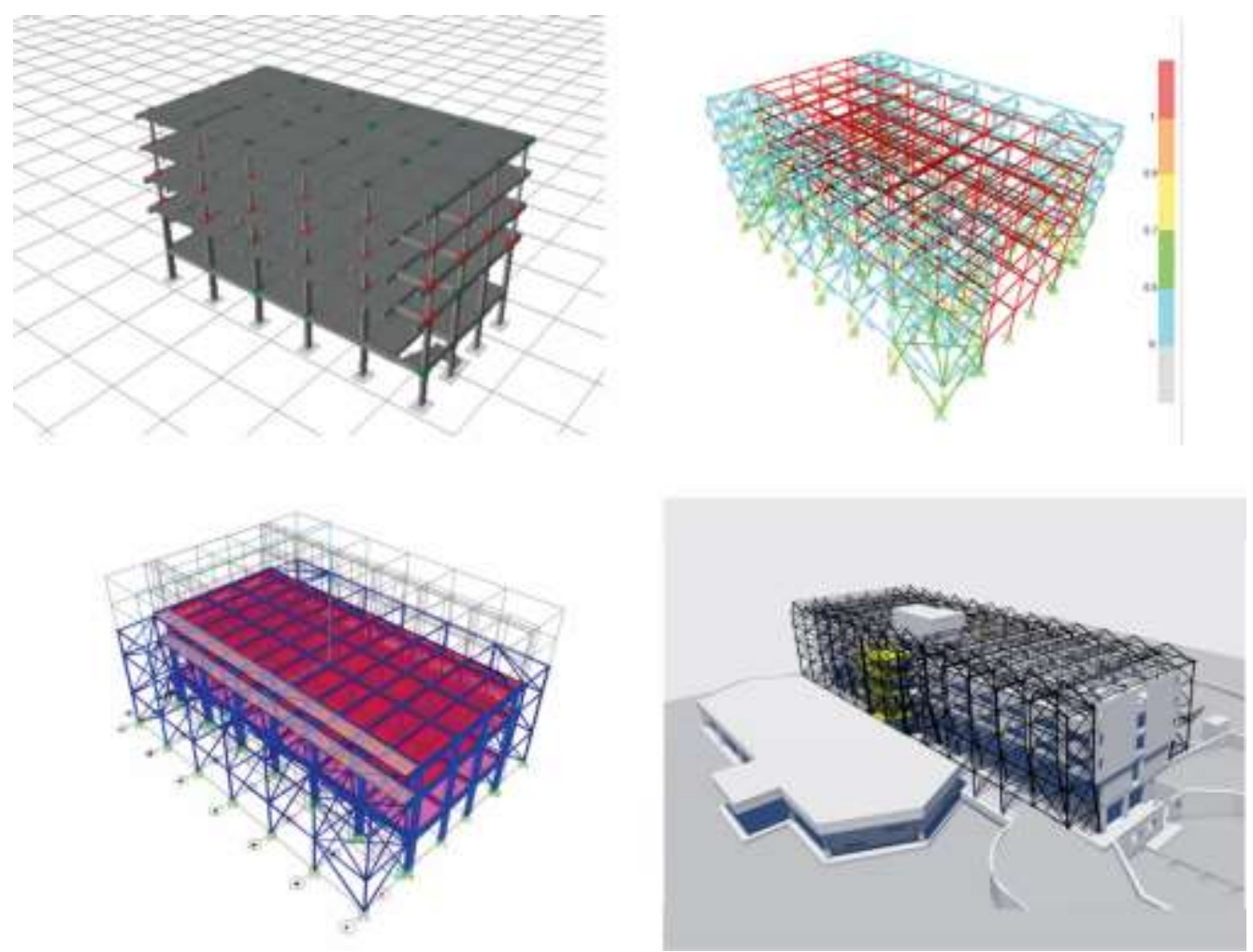

Figure 10. Structural Development of the Proposal: (1) Feasibility Study on the Nodes (2) Modelling of Structure (3) Verification of Sections (4) Final Proposal Source: Drawings and Calculation by A. M. Santoro.

This new beam will be responsible for resisting the loads applied by the vertical planes on them and transmitting these actions (Figure 11).

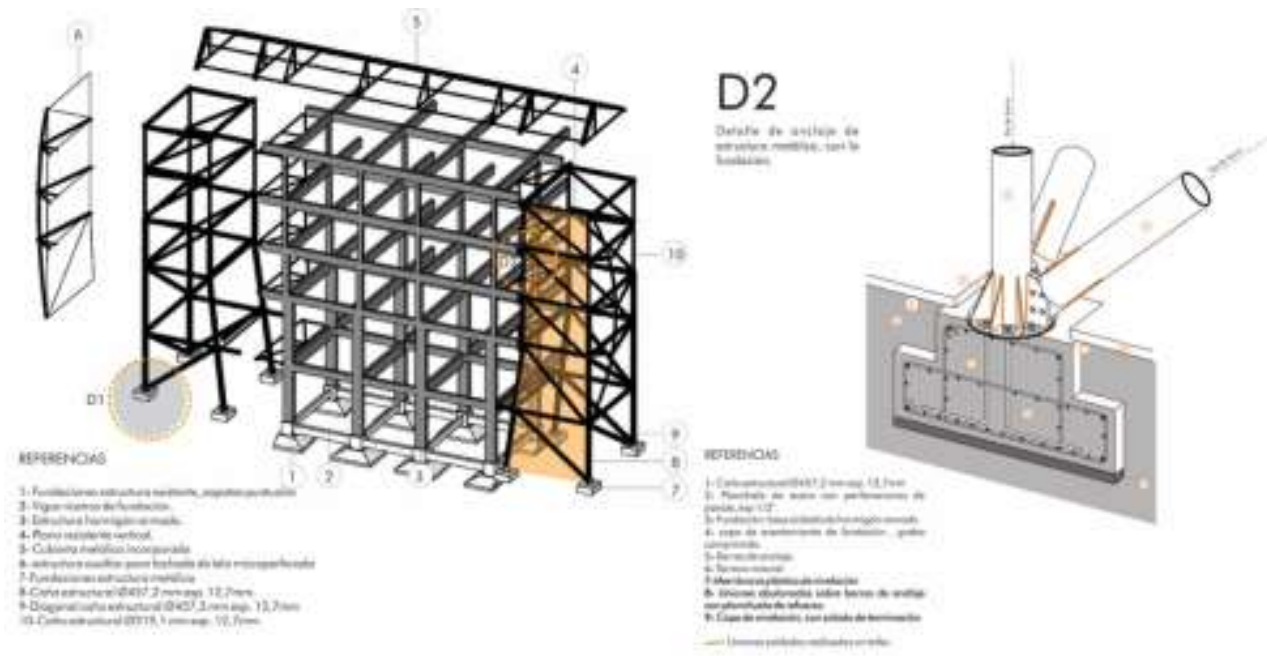

Figure 11. Details of the Main Connections Post-Project Source: Drawings and Calculation by A. M. Santoro. 
After modelling the whole structure with SAP2000, two pertinent verifications were performed. The first was to verify that the steel sections do not creep under seismic loads, according to the limits set by the regulations; the second was carried out by checking the movements of the structures in both the directions. ${ }^{15}$

\section{Sustainability}

Nowadays, sustainability is one of the most important parameters to take into consideration, assumed as the capacity to reduce waste and to use natural resources. For this reason, three systems that work simultaneously were designed, allowing the project to become self-sufficient (Figure 12).

The first system is the use of solar energy with the implementation of photovoltaic panels, incorporated at the end of the metal roof. The energy collected is used to power the building electrically and, in the winter period, is used for the operation of boilers, which operate a radiant floor system.

The second system contemplates the reuse of rainwater. The water is collected by a system of gutters placed on the roof and conveyed to filters, to then be accumulated in a tank located on the ground floor. Finally, the shape of the designed facade allows us to take advantage of the winds of the area and to obtain the correct ventilation of the whole proposal.

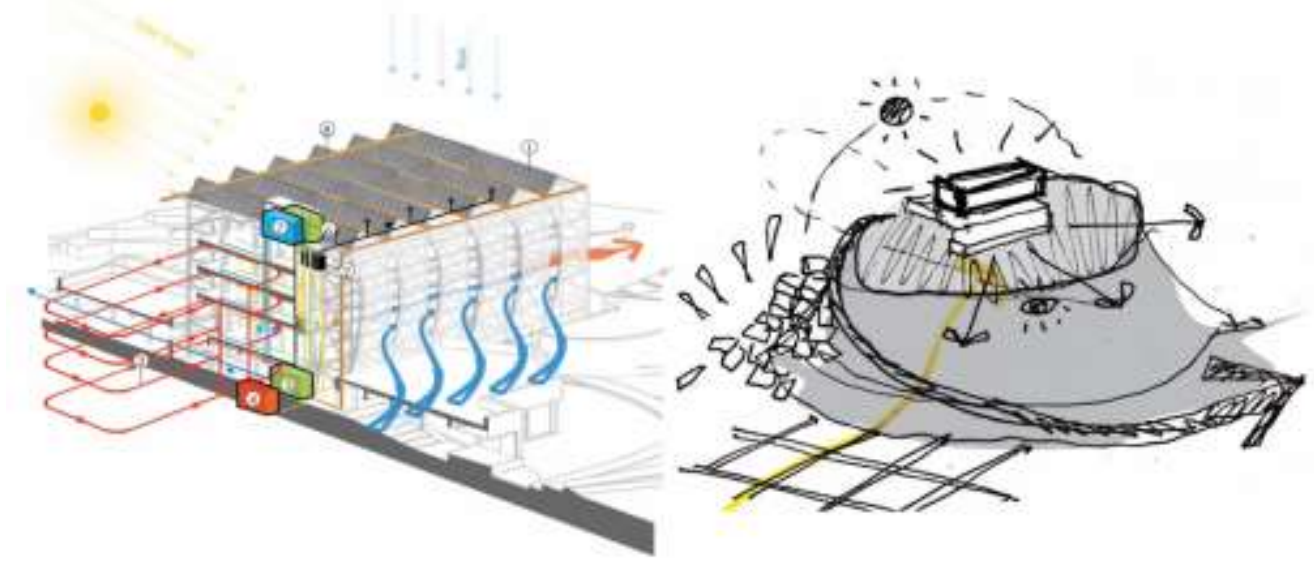

Figure 12. Functioning of the Systems for the Use of Natural Resources. Use of the Sun's Energy (1,2); Heating with Radiant Floor Systems (3,4); Reuse of Rainwater $(5,6,7,8)$

Source: Drawings by Authors.

Furthermore, the sustainability aspects in the building are classified into four groups of environmental, social, economic ${ }^{16}$ and technical issues. ${ }^{17}$

15. The structural analysis has foreseen numerous verifications that it is impossible to report in this scientific contribution, since it is intended to demonstrate mainly the effectiveness of the holistic approach in architecture.

16. The economic aspects are identified as follow up research areas. 
If the cultural asset is recognized as a non-renewable and limited resource, then its conservation and safeguarding become a priority needs of the community. Recovery and enhancement of the existing that opposes the consumption of resources and soil is a sustainable operation in itself.

The key issues for achieving the goals of sustainability, especially linked to the recovery of existing heritage, are:

1) Socio-cultural progress that recognizes everyone's needs.

2) Effective protection of the natural and built environment.

3) Recognition of the historical value of the buildings.

4) Prudent use of natural resources.

5) Maintaining high levels of economic growth and employment. ${ }^{18}$

To conclude the project phases, in order to enhance social sustainability, a final questionnaire was administered to the inhabitants of San Martin de los Andes who, after careful examination also thanks to virtual architecture, were able to express their opinion (Figure 13).

Do you believe that a proposal that uses $100 \%$ of the building's potential is necessary?
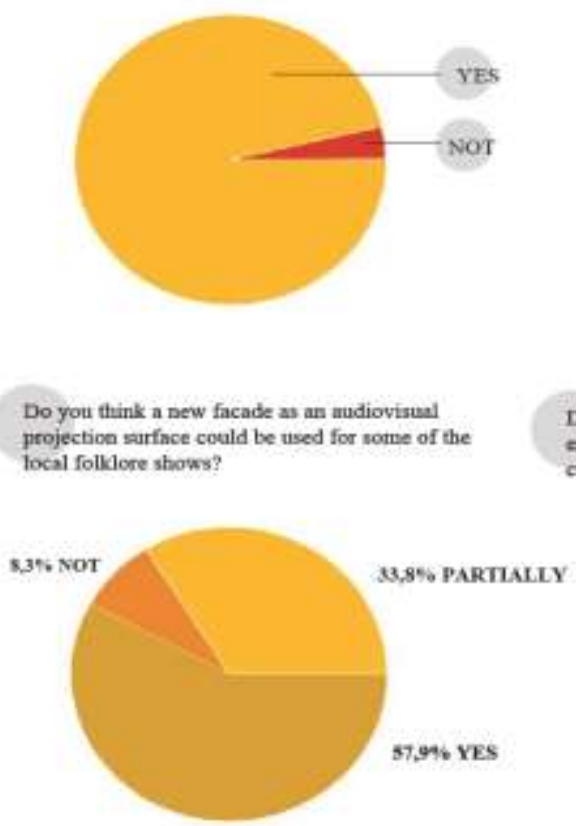

Do you think a new facade as an audiovisual projection surface could be used for some of the hat follace shows?

Do you believe that this proposal can help to enhatec the productive sectors and encourage cultural and educational activities?

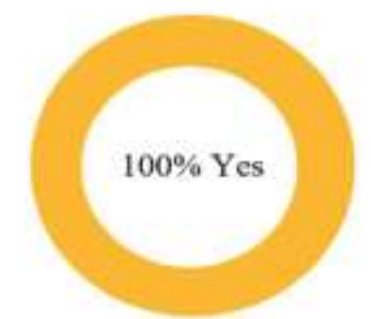

Figure 13. Final Questionnaire on the Appreciation of the Project by the Citizens

17. See H. Zabihi, F. Habib and L. Mirsaeedie, "Sustainability in Building and Construction: Revising Definitions and Concepts," International Journal of Emerging Science and Engineering 2, no. 4 (2012): 570-578.

18. See G. K. C Ding, "Sustainable Construction, the Role of Environmental Assessment Tools," Journal of Environmental Management 86 (2008): 451-464; J. Hwa Bay, "Towards a Fourth Ecology: Social and Environmental Sustainability with Architecture and Urban Design," Journal of Green Building 5, no. 4 (2010): 176-197. 


\section{Discussion and Results}

This work outlines an ideal and operational method based on a) preliminary selection of modern buildings to be conserved, restored and reused; b) careful validation according to the 4 evaluation criteria; c) design practise based on the holistic approach; d) participation of population in any stage of the process.

A validation of the methodological coherence is concretely conducted through a case study, in particular with the aim of recovering and redesigning a giant concrete building in San Martin de los Andes (Argentina).

In general, it is suitable to use the following analysis and intervention methodology.

Each building must be analysed through the four criteria: 1 . creative work of human genius; 2 . influence of innovative technologies; 3 . exceptional example imprinted in the historical memory of people; 4. illustrative example of economic or social developments. It is essential to generate a critical appreciation of the quality of the work, through broad and effective selection criteria, so as to be able to orient the choices towards more careful intervention. ${ }^{19}$

Subsequently, an interdisciplinary recovery project is proposed, in accordance with the four main components of the architectural project. The contemporary project allows to preserve and maintain the existing building avoiding losing a key construction in the history of the city and the local landscape. At the same time, it allows to generate new comfortable accommodations and transition spaces between the different volumes, to divide the different functions and to organize the horizontal and vertical circulation of users. The choice of selection criteria and holistic aspects is able to express all the social, cultural, architectural and urban effects involved in the design and construction of a work.

The structural components must preferably be analysed by non-destructive tests in order to define the mechanical parameters to be adopted to perform the structural evaluations (in this project, a metal exoskeleton with high rigidity was designed that solves structural and functional problems, becoming a peculiar figurative feature of the artifact).

Moreover, each project must be treated according to an all-inclusive approach in which any aspect cooperates to achieve the final objective. It is recommended to use the 4 selection criteria during the analysis phase of the works and, subsequently, the 4 inclusive parameters (society, architectural design, structure, sustainability) in the conception, design and realization processes.

The methodology could be extended to numerous examples of modern architecture, so as to create a map of buildings worthy of being recovered and preserved. The 4 selection criteria ensure compliance with art. 1 of the Venice Charter for which all the evidence of a particular civilization, a significant evolution or a historical event must be preserved and protected. This notion applies not only to great monumental works but also to those which gained a cultural significance over time.

19. See MacDonald, "20th Century Heritage: Recognition, Protection and Practical Challenges," in ICOMOS World Report 2002-2003 on Monuments and Sites in Danger, 2003. 


\section{Conclusions}

Holistic approach to recover the existing buildings means to manage the intervention, according to the uniqueness of each construction and ensure its enjoyment over time, through compatible, reversible and distinguishable solutions.

The conservation of $20^{\text {th }}$ century production includes the analysis of the ambiguities related to the modern techniques and purposes. In fact, according to numerous positions, contemporary production is absolutely not comparable to that of past artistic and constructive seasons, because it is not made up of unique, unrepeatable and unreproducible items, but of serial and industrial combinations. The theme of "seriality" did not allow the protection and conservation of many works which, due to their more modern and industrial character, seem to require easier solutions and, above all, more rapid reproducibility operations. These reflections certainly do not consider all those aspects that construction techniques or new materials generated in the creation of the "modern".

It is necessary to overcome the ambiguity of the modern architecture linked only to industrial production and economic speculation, in order to evaluate all the examples on a case-by-case basis and to provide the same care reserved for Medieval, Renaissance or Baroque buildings. This makes possible to overcome any issues related only to the composition/decay relationship of materials or to the maintenance of each elements. With regard to modern production, pre-packaged solutions cannot be implemented, but the formal and technological peculiarities of the modern buildings require wider reflections that can bring the practice back to the methodological rigor typical of conservation and restoration discipline.

Today architectural conservation/transformation/maintenance cannot ignore the challenges evoked by an emerging awareness of cultural and operational change towards more sustainable goals of efficiency, efficacy, safety and functionality, without neglecting ethical and aesthetic demands.

Therefore, it is necessary to address these issues in an interdisciplinary scientific approach, so Academies, Institutions, professionals and communities will be able to reactivate the cultural debate that has made possible to preserve the historical heritage over time and to conserve and recover the modern production, rich in tangible and intangible values.

\section{Bibliography}

Albrecht, J. "Towards a Theory of Participation in Architecture. An Examination of Humanistic Planning Theories.” Journal of Architectural Education 42, no. 1 (1988): 24-31.

Barthel-Bouchier, D. Cultural Heritage and the Challenge of Sustainability. New York: Routledge, 2013.

Cerverathe, J. "Decline of Modernist Architecture: Deterioration, Obsolescence and Ruins." Palapa. Revista de Investigación Científica en Arquitectura IV, no. II (2009): $29-43$.

Crippa, M. A. "Per il Restauro del Moderno. Qualche Riflessione sul Riconoscimento e il Progetto di Restauro di Architettura del Novecento." [For the Restoration of the 
Modern. Some Reflections on the Recognition and the Restoration Project of Twentieth Century Architecture.] Territorio Nuova Serie, no. 26 (2003).

Ding, G. K. C. "Sustainable Construction, the Role of Environmental AssessmentTools." Journal of Environmental Management 86 (2008): 451-464.

Garda, E. "Gli edifici del Movimento Moderno. Caratteristiche costruttive e compositive." [The Buildings of the Modern Movement. Constructive and Compositional Characteristics.] In Manuale del Recupero Edilizio. Edifici in Muratura e in Cemento Armato, 134-139. Edited by F. Astrua and R. Nelva. Santarcangelo di Romagna (RN): Maggioli Editore, 2017.

Hwa Bay, J. "Towards a Fourth Ecology: Social and Environmental Sustainability with Architecture and Urban Design.” Journal of Green Building 5, no. 4 (2010): 176-197.

Jenkins P. and Forsyth L., Architecture, Participation and Society (New York: Routledge, 2010).

Kealy, L. and S. F. Musso (Eds.) Conservation/Transformation, Transactions on Architectural Education. Leuven: EAAE, 2011.

Macdonald, S. "Reconciling Authenticity and Repair in the Conservation of Modem Architecture." Journal of Architectural Conservation, no. 1 (1996): 36-54.

MacDonald, S. " $20^{\text {th }}$ Century Heritage: Recognition, Protection and Practical Challenges." In ICOMOS World Report 2002-2003 on Monuments and Sites in Danger. 2003.

Paschoalin, R. and M. T. Barbosa. "Restoration of the Cathedral of Brasilia: Challenges and Conflicts of Restoration of Modern Architecture." Conservar Património 18 (2013): 45-53.

Picchione, M. G. "La Tutela delle Opere di Architettura Contemporanea." [The protection of works of contemporary architecture.] L'Architetto Italiano, no. 4 (2004).

Portugali, N. The Act of Creation and the Spirit of a Place: A Holistic-Phenomenological Approach to Architecture. Fellbach: Edition Axel Menges, 2006.

Powell, K. Architecture Reborn. Converting Old Buildings for New Uses. New York: Rizzoli International Publications Inc., 1999.

Rodwell, D. The Achievement of Exemplary Practice in the Protection of our Built Heritage: The Need for a Holistic Conservation and Sustainability. Orientated Vision and Framework. Bucharest: UNESCO, Management of Private Property in the Historic City-Centres of the European Cities-in-Transition, Proceedings of UNESCO International Seminar, 2001, 127-153.

Sanders, R., B. Shepherd, E. Skowronek and A. Hoffmann. "Sustainable Restoration of Yale University's Art + Architecture Building." Association for Preservation Technology International Bulletin vol. 42, no. 2/3, Special Issue on Modern Heritage, (2011): 29-35.

Shankland, G. "Conservation through Planning." In Conservation and Development in Historic Towns and Cities, 73-82. Edited by P. Ward. Oxford: Oriel Press, 1968.

Zabihi, H., F. Habib and L. Mirsaeedie. "Sustainability in Building and Construction: Revising Definitions and Concepts." International Journal of Emerging Science and Engineering 2, no. 4 (2012): 570-578. 



\title{
A Live Interior: Environments, Assemblies, Materialities
}

\author{
By Ulrika Karlsson ${ }^{*}$, Cecilia Lundbäck ${ }^{ \pm}$, Daniel Norell ${ }^{*}$, \\ Einar Rodhe ${ }^{+} \&$ Veronica Skeppe ${ }^{\S}$
}

\begin{abstract}
This paper examines the interior as a condition that is continuously in production through the arrangement of objects and furniture. This is done along two lines of inquiry. First by examining a few different historical and contemporary conceptions of the domestic interior through the lens of architectural representation. Second by using the technique of laser scanning to document a number of inhabited interiors in two apartment buildings. Through a series of representations, or cloud drawings, produced from the scans, the paper presents three ways of reading the interior: as environments, as assemblies, and as materialities. Departing from Robin Evans' writing on drawing techniques for representing the interior and their correlation to ways of inhabitation, the paper poses questions around how the understanding of the interior may shift when using emerging techniques for architectural representation. Through readings of Walter Benjamin as well as Sylvia Lavin, the paper discusses such shifts in relation to changes in the conception of the interior and the objects that it contains.
\end{abstract}

\section{Introduction}

The domestic interior can be understood as a live environment, shaped by elements of varying temporality. Wallpaper, baseboards, mouldings, and flooring typically have a shorter duration than the architectural framework that supports them. Furniture as well as textiles, plants and the myriad of smaller items that occupy desks and shelves are rearranged in a continuous negotiation between the interior and its inhabitants. Overall, this makes the domestic interior an unstable condition, constantly in production.

Domestic interiors present a specific set of issues for architectural representation. While the exterior of a building often can be captured in its totality in a set of elevations, a void inside it, such as a room, typically becomes fractured by plan and section cuts that slice through it. Further, unlike the exterior, the interior mediates between architecture and human habitation through accommodation of everyday domestic life. A floor plan, for example, has in this sense been characterized by Pier Vittorio Aureli as a "concrete abstraction", since it "translates many determinations - money, measures, code, gender, class, rituals,

\footnotetext{
*Professor, School of Architecture, KTH Royal Institute of Technology, Sweden.

${ }^{ \pm}$Lecturer, School of Architecture, KTH Royal Institute of Technology, Sweden.

Senior Lecturer, Department of Architecture and Civil Engineering, Chalmers University of Technology, Sweden.

${ }^{+}$Senior Lecturer, Konstfack, College of Arts, Crafts and Design, Sweden.

${ }^{\S}$ Research Engineer, School of Architecture, KTH Royal Institute of Technology, Sweden.
} 
beliefs, ideologies, environmental conditions, etc. - into a specific spatial layout."1 Yet, as life in the interior is played out across scales - from rooms, to furniture, to objects - much of it often eludes being addressed in the abstracted language of architectural drawing. This is an issue of medium specificity as well as of disciplinary boundaries. Drawing has historically been conditioned by the practice of outlining, of drawing contours with lines, which promotes engagement with some properties of surfaces and objects while downplaying others. In addition, what becomes included or excluded in a drawing is dependent on professional responsibilities, belonging to fields such as architecture, interior architecture, furniture design, or industrial design.

By surveying contemporary domestic scenes in drawings, the research project Interiors Matter: A Live Interior examines the interior as an unstable condition, continuously produced through the arrangement of objects and furniture (Figure 1). The project explores laser scanning as a specific means of documentation of everyday domestic interiors and as a medium of drawing. This is done through the disciplinary lens of architectural representation, as well as by looking at different conceptions of the domestic interior and the objects that it may contain. In summary, this paper and the drawings contained in it, raise two questions: How is instability affecting the production of an interior environment? How can aspects of an interior's instability be captured, documented, or replicated using point clouds obtained through laser scanning?

The paper is structured as follows. Background and relevant literature are introduced in two sections. First, Representation and Inhabitation outlines how the historical development of techniques for representing the interior can be paralleled with the development of spatial practices of inhabitation. Second, From Collection to Stuff outlines how the interior can be understood through the organization of furniture and objects that it contains. The following section, Capturing the Live Interior, introduces $3 \mathrm{~d}$-scanning as a method as well as a spatial practice and describes how the interiors studied in the project were documented through a combination of laser scanning and photography. Results and findings are explored in two sections. Cloud Drawings focuses on the particularities of point clouds as a medium of representation, and Environments, Assemblies, Materialities discusses cloud drawings in relation to these three ways of reading the interior. Finally, the Conclusions section discusses how the cloud drawings developed in the project can open for new ways of understanding and conceptualizing the interior

1. P. V. Aureli, "Life, Abstracted: Notes on the Floor Plan”, E-flux Journal ( 2017) Retrieved from: https://www.e-flux.com/architecture/representation/159199/life-abstracted-notes-on-the-floorplan/ [Accessed 26 October 2020]. 


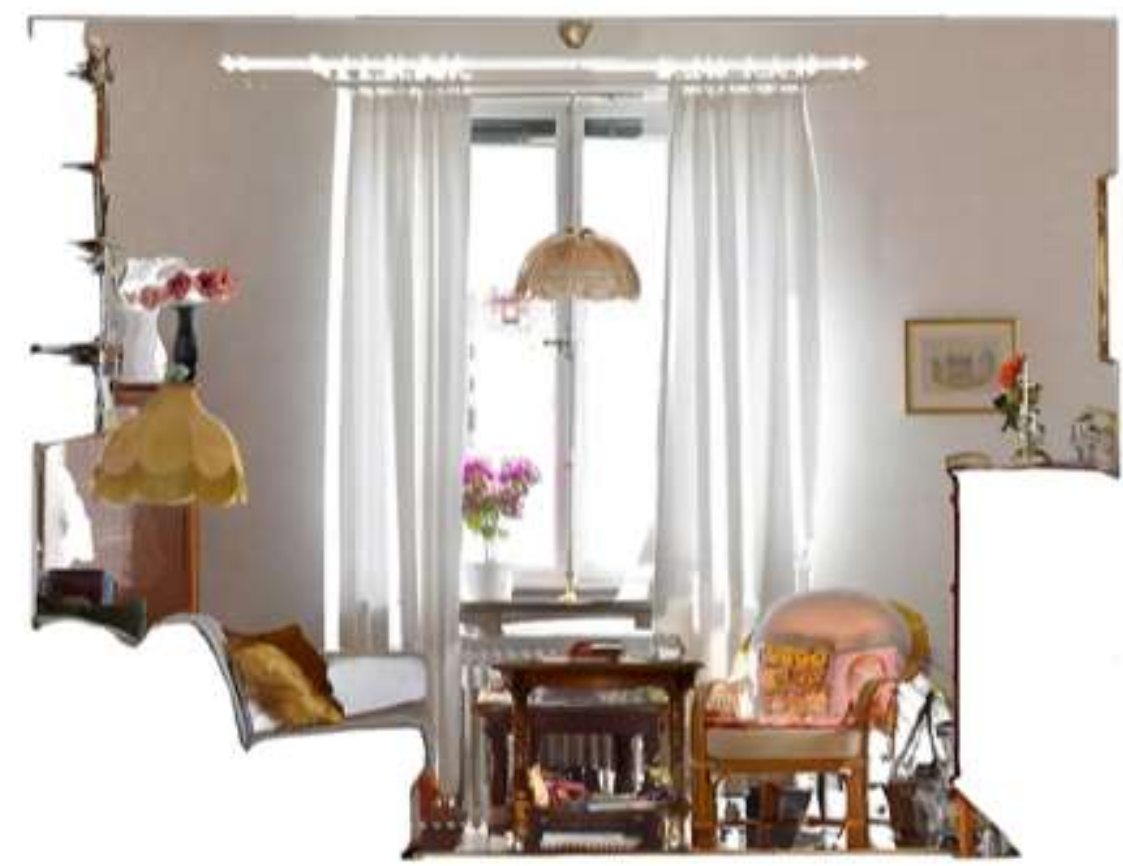

Figure 1. Interiors Matter: A Live Interior. Section view of point cloud acquired through laser scanning of a room in an apartment, Stockholm, 2019. Equal weight is assigned to ceiling, walls, floor and interior belongings. Parts of the room are invisible to the scanner and appears as white gaps or "drop shadows" behind the vase and the curtain rod.

Source: Authors.

\section{Representation and Inhabitation}

The historical development of techniques for representing the interior can be paralleled with the development of spatial practices of inhabitation. Charles Rice has described this as a "doubleness" in how the interior was conceived and developed. ${ }^{2}$ The notion of the interior emerged both in its physical presence and use as well as in the two-dimensional representations of interiors. Over time, representational techniques and spatial conditions "emerge, develop, transform and are abandoned together" and in so doing, continuously produce different conceptions of the interior. ${ }^{3}$

2. C. Rice, The Emergence of the Interior: Architecture, Modernity, Domesticity (London and New York: Routledge, 2007), 20.

3. Ibid, 26. 
A well-known reference relating modes of architectural drawing to changes in social life is Robin Evans' "The Developed Surface: An Enquiry into the Brief Life of an Eighteenth-Century Drawing Technique."4 In England during the 18th century it was common practice that interiors of palaces and villas were described in section drawings that sliced through the building in its entirety. While these sections were highly detailed, containing wall coverings, colour schemes, and décor, they emphasised the relation between rooms rather than giving a complete description of any one room. During this period, architects such as the Adam brothers developed a new kind of drawing, referred to by Evans as the "developed surface interior", or "room portrait." The room portrait showed all wall elevations as if unfolded from the plan, so that the surfaces that delimited a room, with the exception of the ceiling, were described in five discontinuous but aligned planes (Figure 2). The developed surface drawings of each room emphasized the individuality of each single space, through consistency in style, ornaments and furnishing. The use of this drawing technique was paralleled in the development of space plan organisations where the single room was increasingly detached from its situation in the larger building and became "a totally encompassing enterprise." Floor plans focused less on hierarchical relationships and the sequence of rooms, but instead introduced difference through the shape of each room.

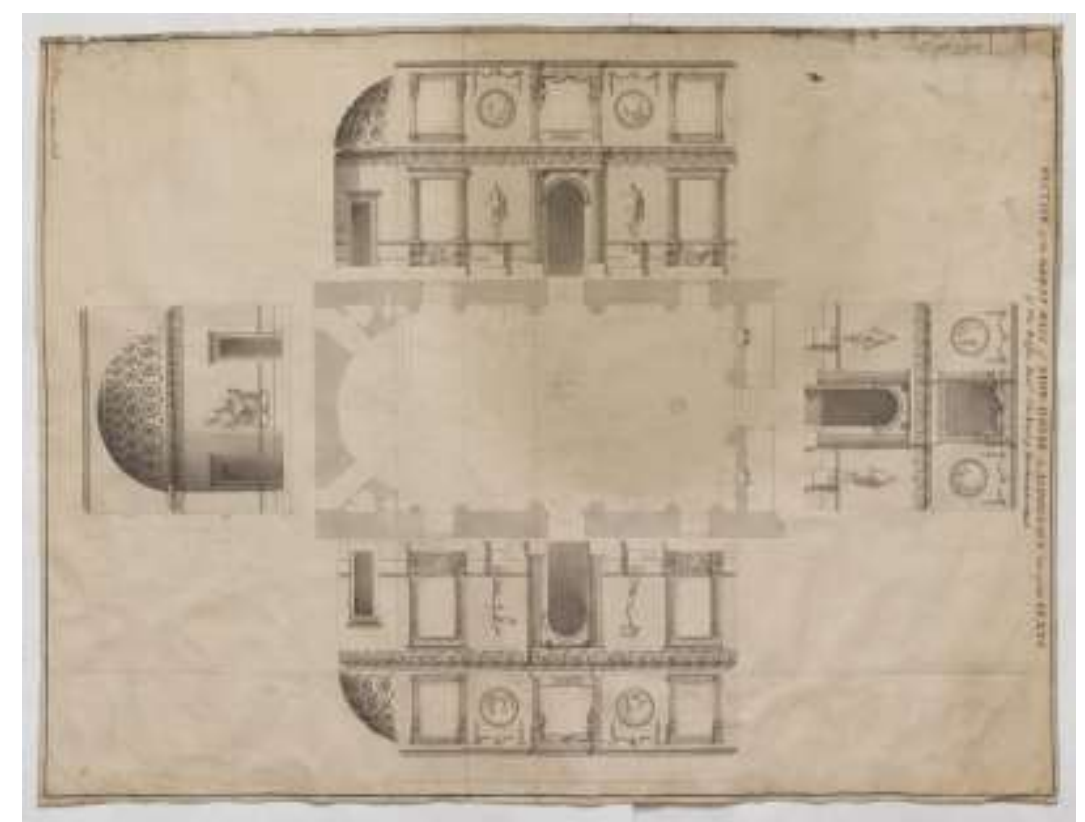

Figure 2. "Section" of the Great Hall at Syon House, by Robert Adam, 1761. A room portrait consisting of one plan and four unfolded elevations. Source: (C) Sir John Soane's Museum, London.

4. R. Evans, "The Developed Surface: An Enquiry into the Brief Life of an EighteenthCentury Drawing Technique," in Translations from Drawing to Building (Cambridge: The MIT Press, [1989] 1997), 194-231.

5. Ibid, 202-204.

6. Ibid, 207. 
The room portrait was not just one of many unbiased ways of describing an interior, but an architectural proposition in itself. It suggested an approach to the design of interiors where articulation was pushed to the periphery of the room, so that any freestanding objects would neatly fall into one of the elevations of the walls. In addition, Evans parallels the developed surface drawing's focus on the edges of the room with social customs and habits of the time. Inhabitants occupied rooms along their walls, often accommodated by a ring of chairs. When furniture became easier to move around at the beginning of the $19^{\text {th }}$ century, a shift of focus from wall to floor took place. Chairs and tables were arranged in the middle of the floor on a more regular basis, creating a "miniature internal landscape" that disengaged from the walls. ${ }^{7}$ The circular organization around a perimeter of a room changed to an intimate clustered occupation of the floor.

At this point one may begin to understand Evans' essay as an inquiry into the difficulties (and frustrations) of constructing a complete architectural representation of a room. For what happens to objects that are grouped on the floor when shown in a developed surface drawing? Should these objects be included in plan but omitted in the elevations of the walls? Or should they be included in all of the elevations? Or just one? And where does one position the sectional cuts through the interior needed for the elevations?

The eventual decline of the use of room portraits and their accompanying design principles can be understood as a loosening of the connection between the furnishings of an interior and its walls, floors and ceilings. Such a loosening can also become evident if an interior is examined after it has been inhabited. In the 1990s, Stewart Brand used "re-photography" - sequences of photographs of interiors captured from the same viewpoint over time - to make a case for how buildings, including their interiors, "learn" as time passes. ${ }^{8}$ Rather than depicting an ideal or intended state when furnished as anticipated by the designer, these photographs document a part of a room post occupancy, complete with everyday objects. A striking feature of most of the photographs is that the visual and spatial impact of objects and furniture, or "mobilia", often exceeds that of its architectural framework (Figure 3). The "learning" can be understood as a constant negotiation between the interior and its inhabitants, where both need to "shape and reshape themselves to each other until there's some kind of tolerable fit." The deployment of mobilia seems to be instrumental in finding the fit, and the photographs often document how objects are used beyond their intended function to open up new possibilities of inhabitation.

7. Ibid, 219.

8. S. Brand, How Buildings Learn: What Happens After They're Built (New York: Penguin Books, 1994), 212-213.

9. Ibid, 164. 

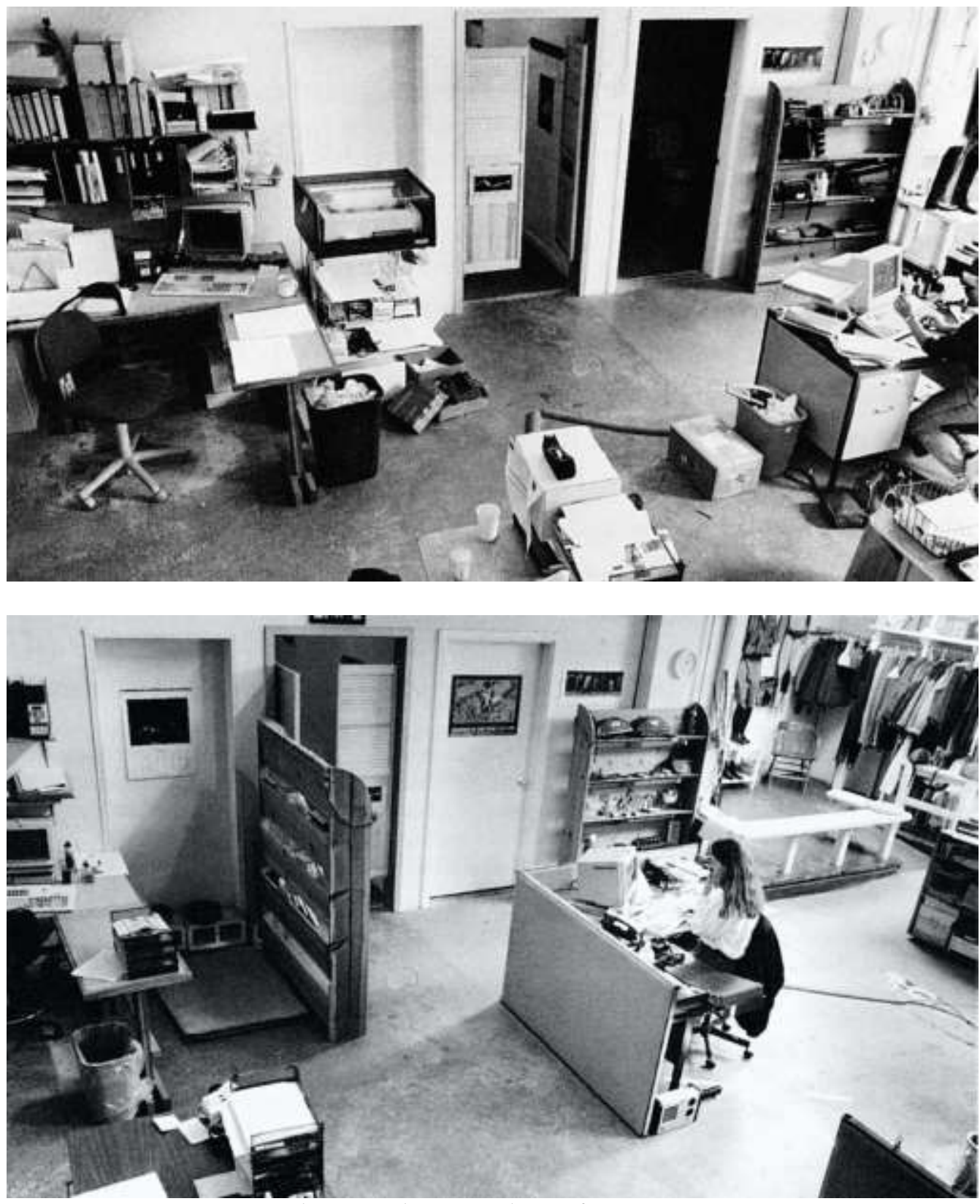

Figure 3. Stewart Brand's "re-photography" of an interior, 1991 (top) and 1992 (bottom). The study indicates the extent to which furniture and objects are rearranged over time.

Source: ( ) Stewart Brand.

\section{From Collection to Stuff}

There is a history of understanding the domestic interior through the inhabitants' belongings and how they are organized. In The Arcades Project, Walter Benjamin famously considered the emergence of the bourgeoise interior in 19th century Paris. During this time, industrial production replaced handicraft and 
objects became commodities that lacked the meaning that the bond between maker and user previously had given them. The act of bringing objects into one's home became a "task of divesting things of their commodity character by taking possession of them." $" 10$ The interior became the place in which a new kind of relation formed between a dweller and a collection of domesticated objects. The collection could testify to the fact that the dweller has had a particular experience and transport the mind back to this event. The objects in the collection thus became traces that could be read as a "detective story", allowing an observer an insight into the psyche of the dweller. ${ }^{11}$

In this way, Benjamin saw the interior as being produced in the process of inhabitation, where the interior begins as a void, an immaterial concept, that is subsequently defined materially by objects in it. This way of understanding the interior resonates with an account of the contemporary relation between the interior and its objects given by Sylvia Lavin in "Architecture in Extremis":

Stuff, things that have material lives, is not a secondary addition to the architectural situation, or merely an instrument of personalisation or functional fulfilment; rather it's what gives rise to architecture in the first place. The interior is produced not by walls and other boundaries but by the order, array, and number of objects within, which coalesce into a perceptible environment, not despite their generally varied and unpredictable presence, but by virtue of their objecthood independent of the envelope that contains them. ${ }^{12}$

Just as the word "stuff" is uncountable (a so-called mass noun), the stuff that fills our homes - furniture, books, clothes, houseware, textiles, waste, souvenirs, plants etc. - can be seen as an architectural entity, rather than as separate pieces. The "stuff" can sometimes be of modest amount and have little or subtle impact on the overall space of the interior. In other cases, belongings have been added, stored, and squeezed in, to the extent that they start to fill up the whole interior, claiming increasingly more of its space. The stuff might constrict the inhabitants to the point where it starts to impinge on their freedom or even become suffocating.

There is a threshold at which stuff becomes both a practical and architectural problem. Objects and furniture tend to be derogatively labelled "stuff" when they lack a designated place in the interior. Such a designated place has historically been provided by integrating an object into an overarching composition. Towards the end of the $19^{\text {th }}$ century, with the emergence of Jugendstil, for example, the architect became a total designer that worked across scales from the room to the small object. "The individuality expressed within the interior shifted from being that of the inhabitant, mediated through the collection, and became that of the architect-turned-artist, whose artistic "vision' constricted the inhabitant.",13

The stuff invading the modern domestic interior has partly been dealt with through the deployment of planned storage space. Alex O'Briant describes the

10. W. Benjamin, The Arcades Project (ed.) R. Tiedemann (trans.) H. Eiland and K. McLaughlin (Cambridge: Belknap Press of Harvard University Press, 2002), 9.

11. Ibid, 9, 20.

12. S. Lavin, "Architecture in Extremis," Log 22 (2011): 58.

13. Rice, The Emergence of the Interior: Architecture, Modernity, Domesticity (2007), 17. 
historical development of the closet, which can be said to originate from the residue spaces of $18^{\text {th }}$ century architecture, where the arrangement of geometrically designed rooms of rectangular, circular, hexagonal or elliptic shapes produced small spaces within the thickened walls, or poché, that turned out to be of practical use for storage. ${ }^{14}$ Closets, cupboards and other types of built-in domestic storage has since become a given in any home, holding and hiding the stuff dismissed from being on display in our living rooms or open plan kitchens. The required amount of storage space has increased successively during the last decades. Our stuff is no longer just filling up our closets, but also our basements, attics, garages, garden sheds and self-storage units.

The idea that stuff must either be kept in check by an overarching design sensibility or be kept from sight reveals an issue of authorship, as both approaches attempt to put the category of objects under the architect's control. Whether other approaches with a more relaxed grip on the whereabouts of objects can be considered as less "totalizing" and more flexible has been debated during the last decades. In the arguments of Mark Wigley, any attempt to conceive the interior as an "open" framework for the accommodation of objects that is more indeterminate or incomplete in nature can in itself be understood as a carefully authored aesthetic agenda that does not allow for interference. ${ }^{15}$ Andrew Holder has found this argument to simply be counterintuitive, while Michael Meredith has suggested that it may be possible to escape the totalizing ambition by arranging objects as if they were "campsites" - sites where objects are grouped and positioned without regard for an architectural framework. ${ }^{16}$ Whatever the case, embracing rather than shunning away from the fuzzy category of stuff might according to Sylvia Lavin open up new possibilities:

Imagining new definitions for architecture that include a bigger category of objects, a broader understanding of work, and that engage systems of instability and participation in the process of design no longer need to weaken architecture's cultural project but rather could make it more extreme. ${ }^{17}$

Together, these accounts of the objects in our homes suggest a shift from the idea of a collection, carefully organized by the dweller, to ever increasing amounts of stuff with agencies of its own. Today, space seems to be under constant siege by objects, and the ways in which these objects are used and placed often do not align with their intended purpose. In processes of being tucked away, displaced, or displayed, objects acquire their own lives that in their material and spatial organization redefine the architecture and produces a "live" interior. But despite

14. A. O’Briant, “Gray Space,” Harvard Design Magazine, no.43 (2016): 90-97.

15. M. Wigley, "Whatever Happened to Total Design?" Harvard Design Magazine, no. 5 (1998): 1-8.

16. See A. Holder, "Whatever Happened to 'Whatever Happened to 'Whatever Happened to Total Design?'?"' Harvard Design Magazine, no. 47 (2019): 25-30; M. Meredith, "Whatever Happened to 'Whatever Happened to Total Design?'?: The Momentary Utopian Jouissance of the Bouroullec Brothers." Harvard Design Magazine, no. 29 (2008): 1-3.

17. Lavin, "Architecture in Extremis," (2011): 61. 
recent attempts, architecture may yet have to find a model for the interior that restores stuff as subject worthy of study and design consideration.

\section{Capturing the Live Interior}

The unattainable fantasy of an all-encompassing representation of an interior space that was established with the developed surface drawing has today been reincarnated in point clouds obtained with laser scanning. A survey of a space is no longer necessarily done through manual measuring and drawing notations complemented with photographs that capture qualities such as colour and texture. Laser scanning has folded these processes into one as each coloured point acquired with the scanner captures both the dimensions of the space as well as its phenomenal qualities. The scanner, unlike the eye of a human conducting a survey, does not discriminate between categories of objects or between what has been intentionally designed and what is circumstantial. It dutifully captures a space and all the objects contained in it in millions of points arrayed in a cartesian coordinate system.

The scanner's capacity to capture a space and everything in it has in an uncanny way actualized Benjamin's conceptualisation of the interior as a detective story. Eyal and Ines Weizman, in collaboration with ScanLAB, have used 3Dscanning towards such forensic ends. The work of these practices implies that a scene captured with scanning can be understood as a scenario, a frozen moment in time in which the relation between objects captured begins to unfold a narrative. The diffusion of scanning for the purposes surveying everything from crime scenes to landscapes means that the world is increasingly reconstructed at levels of detail that may constitute an "invasion of privacy." 18

Interiors Matter: A Live Interior explores how interiors are produced by ongoing arrangement and accumulation of belongings, using point clouds obtained with laser scanning as a means of architectural representation. In the first phase of the project, documented in this paper, inhabited interiors in two early to midcentury apartment buildings in Stockholm were documented during 2019. Both buildings contain rentals, implying that rooms and apartments to a large extent are comparable with regards to space plan and finishes. This means that the imprint made by each tenant consists mostly of their furniture and belongings. Although separated by some 20 years (1929 and 1946), the studied apartments in both buildings shared a few characteristics. They were all relatively small - studios or one-bedroom apartments - and they all featured rooms that in their size and space plan did not prescribe a particular layout of furniture.

Rooms in the apartments were documented using laser scanning, also known as LiDAR (Light Detection and Ranging), a method that uses light to measure distances to surfaces that a scanner can "see" from a fixed point in space. The scanner emits a short pulse of light and times how long it takes for the pulse to be

18. M. Shaw and W. Trossell, "Digital Doppelgängers: Future Scanscapes," Architectural Design 84, no. 1, (2014): 22. 
reflected back in order to estimate depth to a point on an object in space. ${ }^{19}$ Each pulse results in a point in a coordinate system and many points together form a point cloud. A scanned interior is constructed as a thin crust of points that envelopes the room by clinging to floor, walls, and ceiling, as well as furniture and objects.

The process of acquisition is based on a logic of assembly of data from a series of rotational scans from different positions, referred to as stations. For each station, a camera with a fisheye lens was used to capture the room in six photographs that were subsequently "stitched" together to a 360-degree panorama. The panorama was projected spherically onto the point cloud in order to give each colourless point in the cloud an RGB colour value. The scanning technique is both spatial and temporal, as each station produces a point cloud specific to its position at a given moment in time. A certain station will provide a clear reading of some surfaces belonging to an interior, while other surfaces will be obstructed from view. Point clouds from several stations are registered and assembled into one in order to get a fairly complete reading of the space and the objects contained in it. The combined cloud is therefore the result of several spatial and temporal recordings. The point clouds were used to produce a series of representations, referred to as cloud drawings.

\section{Cloud Drawings}

Light is pouring through a window, dissolving the white curtain against the wall. A carpet with a small table atop sits in front of the window in the centre of the room. To the left, a grey, plush sofa and a floor lamp with a frilly beige shade. A wooden cabinet supporting a small green vase with red flowers is visible behind the sofa. At the right side of the table stands a rattan armchair with white upholstery and further to the right, against the wall, a wooden chiffonier. Below the chiffonier and armchair piles of books, boxes and unidentifiable objects are dimly seen. Two lampshades seem to levitate above the floor-bound furniture.

This mundane domestic scenery is captured in one of the cloud drawings (Figure 1). As a representation, it bears resemblance to a pointillist painting, or a grainy photograph, while at the same time complying to the conventions of cut and elevation native to an architectural section drawing. It is a recording of a domestic interior from within, captured in 800 million coloured points - a documentation of the framework of the space as well as all objects contained in it. In this matrix of points there are gaps where surfaces are missing behind and below objects. The curtain and its rod cast a white shadow on the wall, objects under the armchair seem to dissolve into a thin mist, and the interior of the chiffonier is missing entirely. These are spots that the beam of the laser scanner has not been able to reach.

When explored through a modelling interface, the point cloud in its unedited state may at first seem incomprehensible and partly impenetrable. Each room, or

19. For a brief summary of the principles of LiDAR, see for example M. Gross and H. Pfister, Point-Based Graphics (ed.) H. Pfister (Elsevier Science \& Technology, 2007), 38. 
sequence of rooms, appears as a positive object formed by negative space. It resembles a cast of the void space of the room, a comprehension of space that has been popularized by artist Rachel Whiteread's casts such as Ghost (1990). This often nearly closed volume (Figure 4) needs to be clipped with a plane in order to get views of the room from the inside. Most of the cloud drawings presented here explore clipping as a way to reveal different aspects of the interior and the relation between the architectural framework and the objects of the interior.

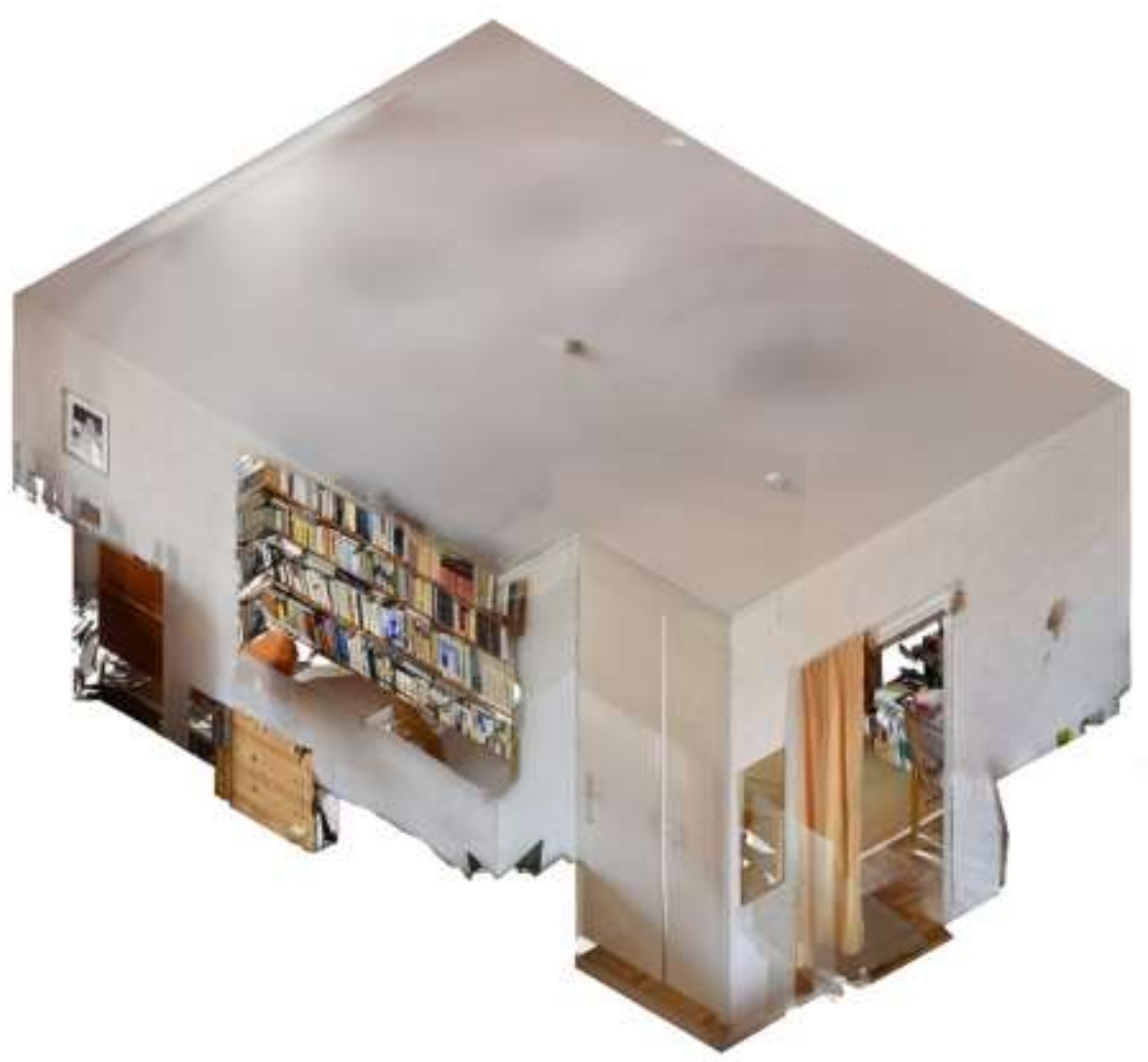

Figure 4. Interiors Matter: A Live Interior. Isometric view of unedited point cloud acquired through laser scanning a room in an apartment, Stockholm, 2019. The room appears as a positive cast of negative space.

Source: Authors.

Some of the scanned rooms were crowded with stuff, almost as if walls and floors had become encrusted with furniture and objects. In one set of drawings the walls, floor, and ceiling of such a room were clipped away (Figure 5). This meant that the entire room could be captured in an exterior elevation - as if it was an aquarium - that compresses the depth of the interior into layers of objects, revealing the extent to which the shape of the room can be defined by the stuff that it contains. Surfaces in the foreground, such as those belonging to a sofa, framed pictures, a corner cupboard, and stack of books, are viewed from behind (hence the mirrored letters), while objects further away from the viewing plane appear as one would expect them to in a typical elevation. The level of detail sustains at least 
two modes of attention: a more distanced viewing where the room is defined by a jumble of distinct objects, and a more myopic view that reveals minute details in each object, as well as messy parts of the point cloud where objects become indistinct due to a lack of resolution.

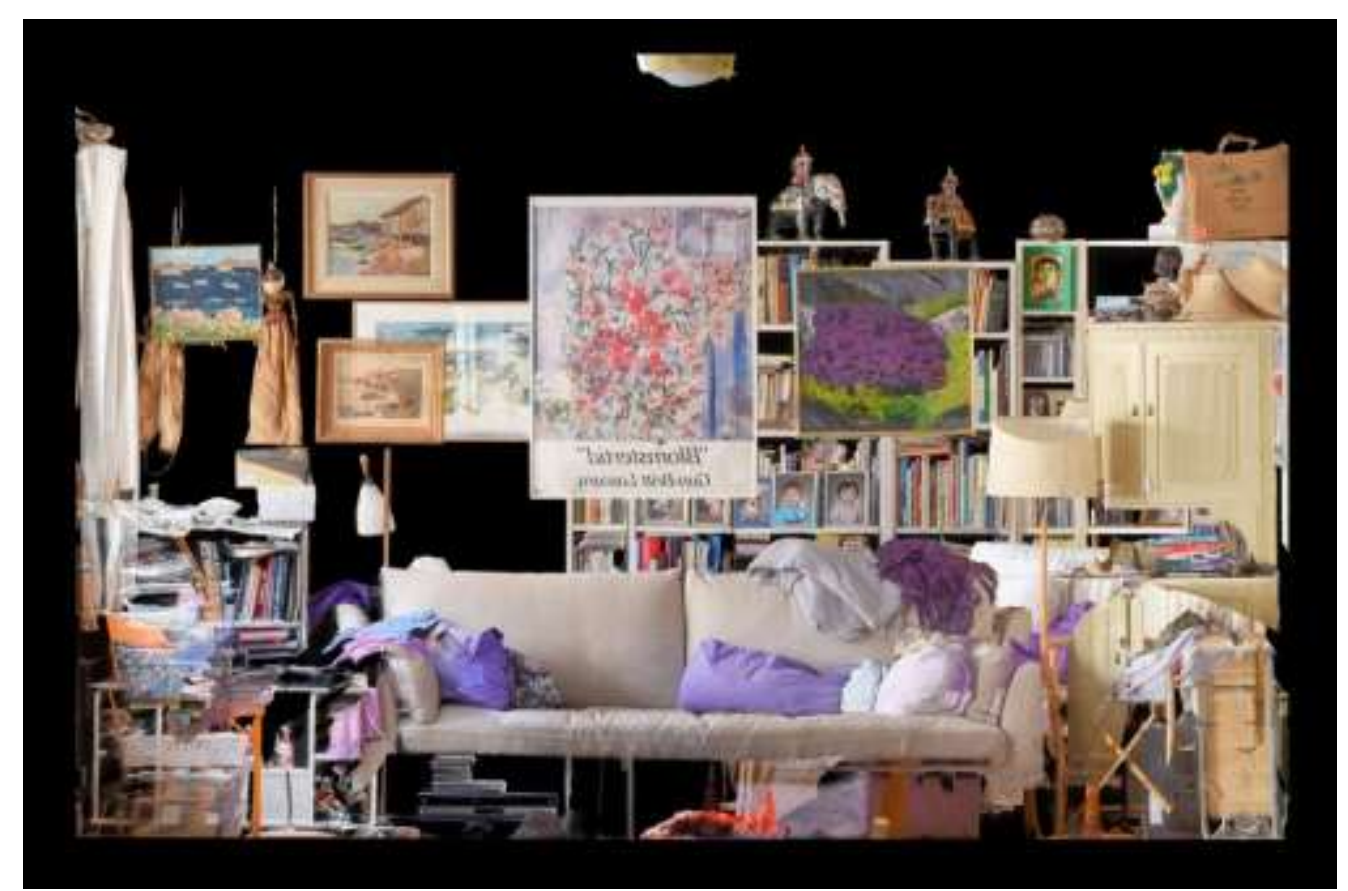

Figure 5. Interiors Matter: A Live Interior. Exterior view of point cloud acquired through laser scanning of a room in an apartment, Stockholm, 2019. Floor, walls, and ceiling have been clipped away, revealing the extent to which the interior is shaped by furniture and objects.

Source: Authors.

The temporal aspect of cloud drawing was explored in an animated drawing that focused on the changing depiction of a flower vase when captured from different stations (Figure 6). A series of still images from the animation show how the level of detail and densities of points change with the position of the scanner. As the viewing angle to the chiffonier and the flower varies, certain parts of objects were captured and others blocked out, producing holes in the cloud shown as white areas in the render. Due to the varying scanner positions, shifting light conditions as well as slight movement, the vase and the flowers appear as ghostly, flickering objects. 


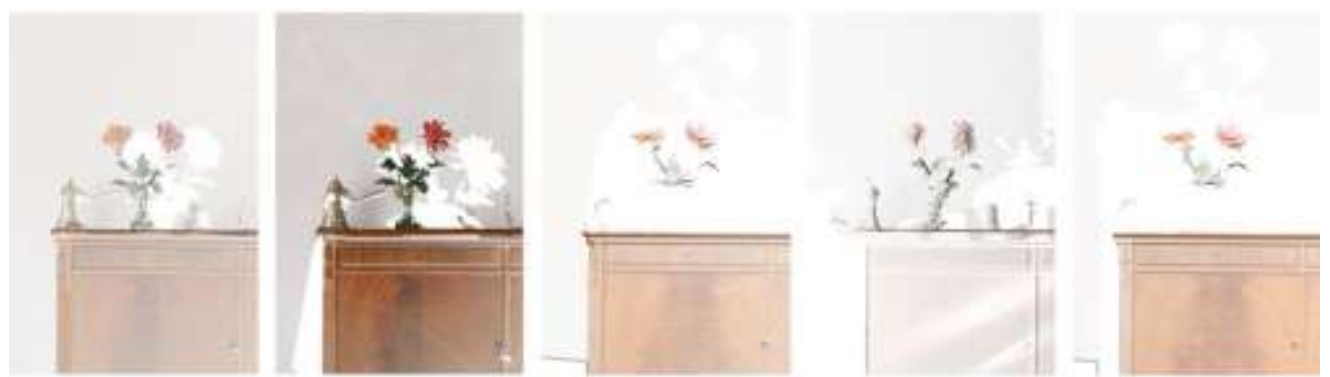

Figure 6. Interiors Matter: A Live Interior. Detail view of point cloud acquired through laser scanning of a room in an apartment, Stockholm, 2019. A series of still images from an animated cloud drawing show how the level of detail and densities of points change with the position of the scanner.

Source: Authors.

There are a number of representational discrepancies between the point cloud and other more common ways of representing architecture. Traditional architectural drawings are constructed of lines, curves and edges that unambiguously define the limits of objects. Cloud drawings, in contrast, consist solely of points and can only illusively produce the reading of a line when multiple points share one coordinate value in a plane. Even a relatively sharp edge in a cloud drawing carries a depth due to the cloud's multilayering of data from different stations. The cloud drawing, especially when clipped to a short depth, suggests a continuity across objects (Figure 7).

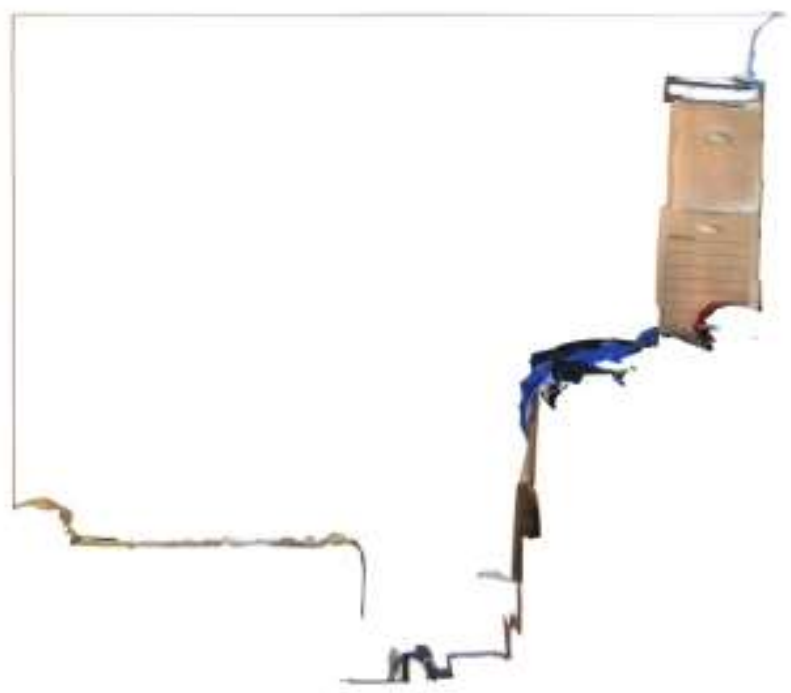

Figure 7. Interiors Matter: A Live Interior. Section of point cloud acquired through laser scanning of a room in an apartment, Stockholm, 2019. The section has been clipped to a short depth, suggesting a continuity between wall, ceiling, and a temporary arrangement of objects.

Source: Authors.

The acquired point clouds appear as complete, high fidelity representations of a room, while at the same time being limited and fragmented. The scanner can 
only capture a surface or an object that it gets an unobstructed view of. Deep recesses or crevices between tightly grouped objects become shadowy areas of missing information. A surface of an object that faces a wall or another object is typically not possible to capture. The point cloud measures visible objects as well as the spots that the scanner cannot see, and these defects are prominently featured even when one does clip the cloud to a view or projection. One set of drawings directs attention to the parts of the room that are invisible from a single station (Figures 1, 6). These drawings feature whiteout areas, such as a "drop shadow" of a vase and a curtain rod on the elevation of the back wall.

It is revealing to compare the effects of the cloud drawings with those of the developed surface drawing technique described by Evans, which provided a certain unification of the interior including drapes, furnishings, wall coverings, objects, etc. The developed surface drawing had a flattening effect on the architecture that it represented that is distinct from the sense of depth and threedimensionality of a cloud drawing. But both modes of representation have a unifying effect as they encapsulate the void of a room, including the perimeter with its furnishings as well as furniture and objects. The developed surface technique affected the design of furniture, as the backsides of chairs and sofas facing a wall often were left undecorated or painted white. Just like the blind spots that appear in a point cloud acquired with laser scanning, these backsides are surfaces that elude both documentation and display (Figures 1, 6, 7).

\section{Environments, Assemblies, Materialities}

As much as the cloud drawings explore the representational particularities of point clouds, they are ultimately a documentation of domestic scenes. The process of editing and formatting the point clouds to arrive at a set of drawings focussed on three ways of reading a scene, through environments, assemblies, and materialities. Together, these notions became a way to discern and conceptualize qualities in drawings as worked progressed. They loosely suggest shifts in scale, from the room or environment, via assemblies of objects, to the materiality of single objects. At the same time, they constitute a way of reading the interior that goes beyond a familiar parsing according to scale. Zooming and clipping might for example focus a drawing on an environment surrounding a single object in a corner of a room.

An environment amounts to the circumstances, objects, or conditions by which something is surrounded. Some of the cloud drawings downplay the importance of individual objects in favour of focusing on an environment as a whole. They direct attention to the ways in which the larger figure of the room is defined by ceiling, walls and floor, as well as by furniture and objects (Figure 1). Stuff may be omnipresent throughout the room in these drawings, but the view and the clipping plane of the section has been selected to suggest a larger environment. The distinction between architecture, furniture, and smaller objects found in a conventional architectural drawing start to break down. The void of the room is as effectively shaped by the distinct corner of ceiling and wall, as it is by a fuzzier 
mass consisting of a bookshelf, a chaise longue, pillows and blankets, a porcelain urn, that seem to have been smeared across the intersection between the wall and the floor (Figure 8). As objects lining the periphery of the room obscure the view of the scanner, they begin to replace floor, walls and ceiling as the delimitation of the room. In some instances, a room is largely defined by an inner layer of surfaces that leave a void in-between object and architecture. These leftover spaces can be characterized as smaller and sometimes blurrier versions of Robert Venturi's notion of "residual spaces", a more or less open layer of surfaces that together shape a space in an interior. ${ }^{20}$

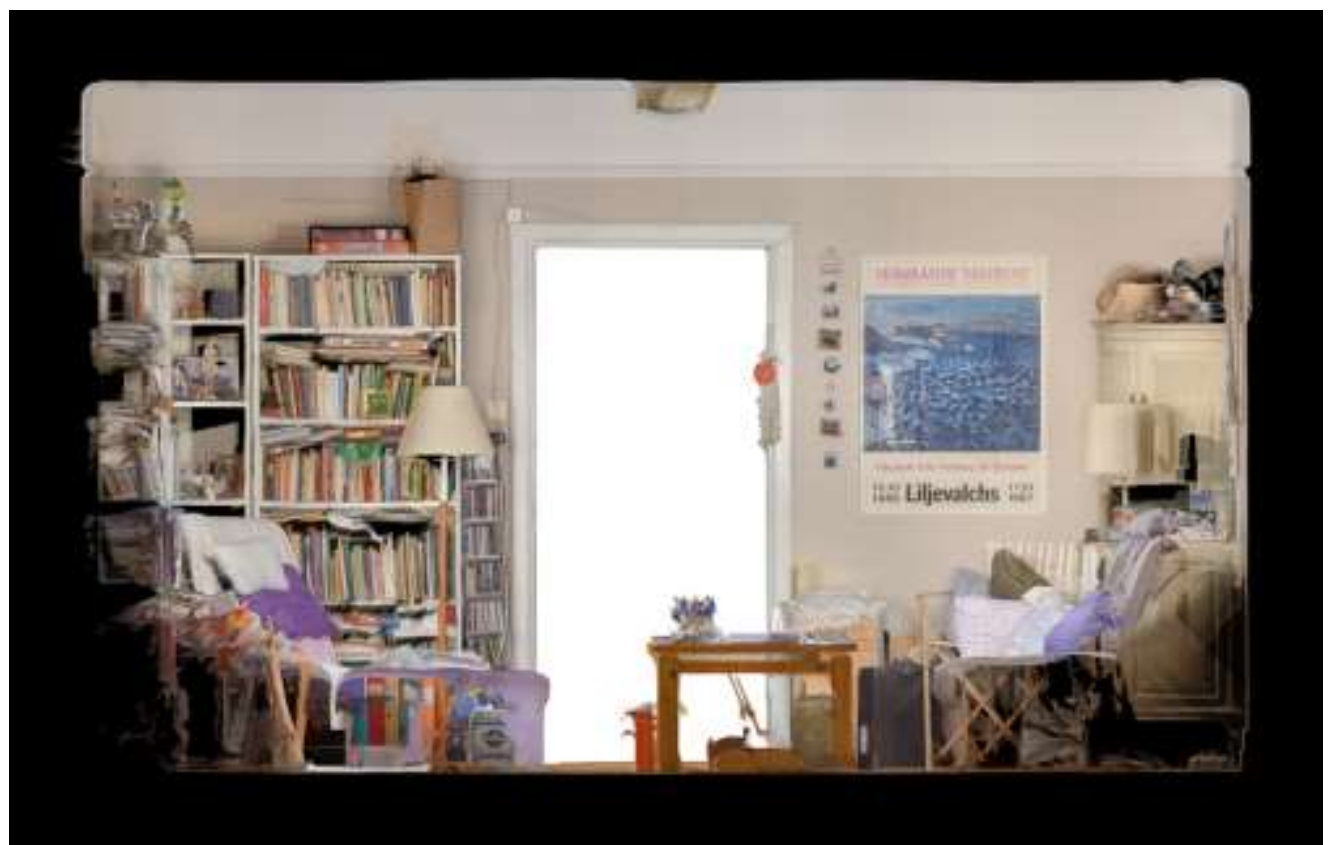

Figure 8. Interiors Matter: A Live Interior. Section of point cloud acquired through laser scanning of a room in an apartment, Stockholm, 2019. As objects lining the periphery of the room obscure the view of the scanner, they begin to replace floor, walls and ceiling as the delimitation of the room. Source: Authors.

Particular arrangements of furniture and objects can be identified as assemblies. This reading reveals hierarchies, adjacencies and interdependencies among domestic items and habits. Assemblies can be highlighted by clipping the point cloud so that the section cut reveals local continuity between two or several objects. This might, for example, allow us to understand "the book and the shelf that it sits on", or similarly "the pillow and the sofa that it sits on", as an assembly and as a new whole, and ultimately as an architectural entity. In some cases, an assembly might be a particular situation of interest. When placed next to lounge chair, a pile of books with a glass on top might together be understood as something else, more similar to a small table. In this way, assemblies may shift

20. R. Venturi, "The Inside and the Outside," in Complexity and Contradiction in Architecture (New York: The Museum of Modern Art, 1966). 
qualities and habits of use associated with one object towards a new, larger entity composed of several objects. Several assemblies were documented in isometric view and compiled in a matrix (Figure 9). Through clipping planes in the $\mathrm{x}, \mathrm{y}$, and $\mathrm{z}$-axis, each assembly emerges as a local mies en scène, formed by walls, floor, or ceiling, as well as by furniture and objects. Some assemblies centre on an inbetween space defined by distinct objects, while others emphasise agglomerations of stuff, such as how a myriad of objects on a table define miniature topography.
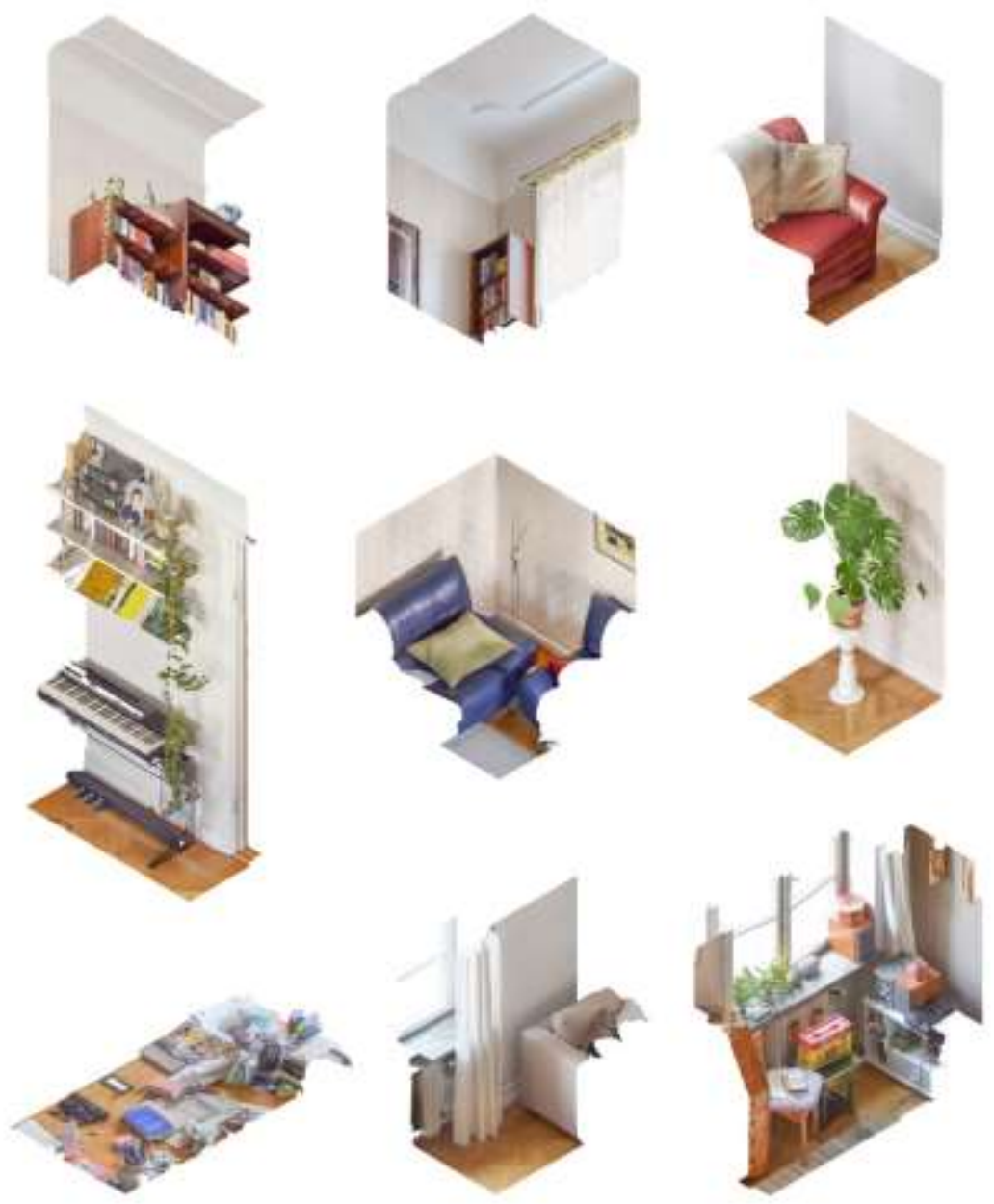

Figure 9. Interiors Matter: A Live Interior. Detailed isometric views of point cloud acquired through laser scanning of a room in an apartment, Stockholm, 2019. Each view has been clipped in order to reveal local assemblies of furniture and objects.

Source: Authors.

Materialities, finally, are considered as the material qualities belonging to an object, such as texture and colour, or highlight and shadow. In the cloud drawings, materialities range from realistic depictions of material effects, to glitches and spots of missing information in the point cloud. A clipped and zoomed-in view of the corner of a sofa, for example, features the subtle shifts in tone belonging to 
wrinkles and stitches on the upholstery (Figure 10). In addition, it reveals the stippled effect of missing points and adjacent points of contrasting colour. The materiality shifts between moments where the medium of the point cloud becomes invisible and other moments where the materiality is highly conditioned by the medium. This is especially true for materials that are reflective or diaphanous in nature. Reflective or transparent materials, such as shiny metals, glass or water will many times elude acquisition because of laser beams being reflected or refracted. The presence of such materials might instead produce disturbances or glitches in nearby areas. The surface of a mirror will reflect the light pulse, so that it appears as if it was an opening to another space, while a thin curtain might disappear momentarily as the laser passes through it. Further, a draught through a room may gently shift the position of lightweight objects that are suspended in the space.

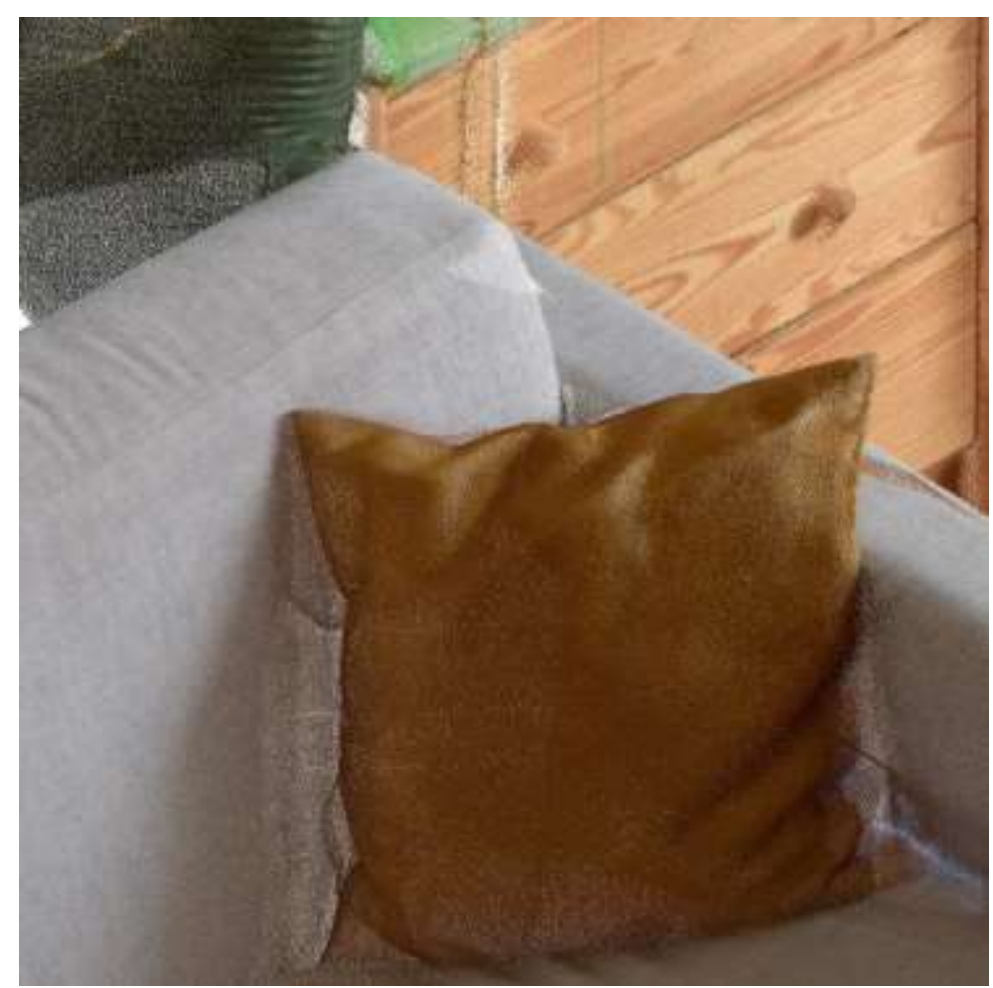

Figure 10. Interiors Matter: A Live Interior. Detailed isometric views of point cloud acquired through laser scanning of a room in an apartment, Stockholm, 2019. Different materialities are mediated through the point cloud, such as the softness of the pillowcase and the wooden grain of the chest of drawers. Source: Authors.

The three categories can be used to study effects at different scales but can also be considered simultaneously to describe parallel or layered qualities. 


\section{Conclusions}

If there is a reciprocal influence between techniques for representing interiors and the development of spatial practice, how may cloud drawings possibly contribute to new notions of what constitutes an interior? And if the relation between architectural delineation and the transitory, provisional placement of stuff historically has shifted between loose and fixed - how can we understand this reciprocity today?

Envisioning new categories for the interior such as environments, assemblies and materialities is an alternative to a more conventional parsing based on different scales or design disciplines. The separation of an interior into architecture, furniture, and objects and further into different professional responsibilities can be a missed opportunity to rethink the interior. This separation, along with the difficulties of representing a space and the artefacts contained in it, may be two reasons why the interior remains an unstable and shifting concept.

In order to be able to address systems of instability of domestic interiors, it is first necessary to be able to document them. Coupling techniques of laser scanning and the processing of point clouds with architectural techniques of representation through elevations, sections and isometric views, the Interiors Matter project attempts to uncover new ways of understanding and conceptualizing the interior. Adopting the scanner's way of seeing, where no distinction is made between scales or types, between the room and the candlestick, makes it possible to assign equal weight to architectural framework, furniture and objects. Everything that stands in the way of the scanner gets surveyed, ignoring disciplinary hierarchies. This mode of documentation puts focus on the informal qualities of a domestic interior, qualities that most likely would go unnoticed if not recorded by the $3 \mathrm{~d}$ scanning.

The cloud drawings presented here reveal new dependencies as well as informal and temporal relationships by cutting through loosely arranged interior belongings. These drawings amount to a proposition for the interior that recasts the messy category and the influential agencies of stuff as an architectural entity.

\section{Acknowledgments}

Interiors Matter: A Live Interior is a three-year artistic research project funded by The Swedish Research Council and hosted by KTH Royal Institute of Technology and Konstfack, College of Arts, Crafts and Design in Stockholm.

\section{Bibliography}

Aureli, P. V. Life, Abstracted: Notes on the Floor Plan. E-flux Architecture, 2017. Retrieved from: https://www.e-flux.com/architecture/representation/159199/life-abs tracted-notes-on-the-floor-plan/. [Accessed 26 October 2020]

Benjamin, W. The Arcades Project. Edited by R. Tiedemann. Translated by H. Eiland and K. McLaughlin. Cambridge: Belknap Press of Harvard University Press, 2002. 
Brand, S. How Buildings Learn: What Happens After They're Built. New York: Penguin Books, 1994.

Evans, R. "The Developed Surface: An Enquiry into the Brief Life of an EighteenthCentury Drawing Technique." In Translations from Drawing to Building, 194-231. Cambridge: The MIT Press, [1989] 1997.

Gross, M. and H. Pfister. Point-Based Graphics. Edited by H. Pfister. Elsevier Science \& Technology, 2007.

Holder, A. "Whatever Happened to 'Whatever Happened to 'Whatever Happened to Total Design?'?" Harvard Design Magazine, no. 47 (2019): 25-30.

Lavin, S. “Architecture in Extremis.” Log 22 (2011): 51-61.

Meredith, M. "Whatever Happened to 'Whatever Happened to Total Design?'?: The Momentary Utopian Jouissance of the Bouroullec Brothers." Harvard Design Magazine, no. 29 (2008): 1-3.

O’Briant, A. “Gray Space.” Harvard Design Magazine, no.43 (2016): 90-97.

Rice, C. The Emergence of the Interior: Architecture, Modernity, Domesticity. London and New York: Routledge, 2007.

Shaw, M. and W. Trossell. "Digital Doppelgängers: Future Scanscapes." Architectural Design 84, no. 1, (2014): 20-29.

Venturi, Robert. "The Inside and the Outside." In Complexity and Contradiction in Architecture, 70-87. New York: The Museum of Modern Art, 1966.

Wigley, M. "Whatever Happened to Total Design?" Harvard Design Magazine, no. 5 (1998): 1-8. 



\title{
Between Earth and Sky: Art and Architecture in Dialogue in the Work of Rui Chafes and Camilo Rebelo
}

\author{
By Raffaella Maddaluno*
}

\begin{abstract}
In a former hotel, bought and remodeled by a seed Portuguese producer, in Switzerland, in one of the underground spaces, an architect and a sculptor, also Portuguese, worked together to give life to an egg-shaped space. A space born from the need to give hospitality to a sculpture, Semente by Rui Chafes, has become a pretext for the reflection on numerous themes; the creative and process interaction between art and architecture, the symbolic force of a form like the egg, the possibility of creating a place inside the space and out of time. This collaboration opens the doors to a second chance of project, the client is the same, the place is Portuguese: Grandola, in Alentejo. This time the theme is housing, a concept that brings with it a series of reflections on the relationship between the identity of the person who designs the space and who will then live in it. The collaboration of the two protagonists is measured on this occasion not only with elements experimented in the previous project (the matter, the material, the form), but also with the landscape (its heights, its extensions), with nature (the colors, the smells, the temperature), with the time that will pass and that will put all this to the test. The present text aims to analyze the artistic path of both architect and sculptor, starting from the story of these two occasions in which art and architecture reach a moment of harmonious tangency in the silence and universality of forms. This analysis will reflect on their creative modes, possibly trying to recognize similarities, tangencies or deep divergences. It will also be an opportunity to continue to reflect on the timeless question of the interconnection between art and architecture.
\end{abstract}

\section{Building a Relationship: Promise}

"The place where Promise is born has the smell of immaterial dreams, the sound of the wind in the dry grass, the intense and merciless light, which I keep in my memory as a project with no beginning or end."

The genealogies of the encounters that give rise to architecture can sometimes constitute a separate story. However, as much you try to apply a rigorous methodology that redesigns the layout of the crossed paths, you must surrender to the inevitable presence of randomness. The history of the project Promise is the result of a meeting of three destinies that cross by chance. Olivier Jacout, the client, Camilo Rebelo (1972), architect from Porto, and Rui Chafes (1966), sculptor from Lisbon. The three meet around a table, and the client's request for the architect is bizarre, almost naive. "You work architecture like a sculptor: I would like you to design me a sculpture where you can live." He does not provide a detailed description for this request, only a handful of indications: two rooms, a

*Assistant Professor, Lisbon School of Architecture, CIAUD, Portugal.

1. R. Chafes, Promise. Interview (ed) R. Maddaluno. Lisboa. [20 July 2020.] 
house for the farmer, an open-air water tank, and a place for his collection of cars. The meeting was sealed, and the challenge accepted, after a short time, again by chance, the opportunity for the location shows itself, the land of Grandôla, in the Portuguese Alentejo. A place of two facets, one towards the sea, with Comporta pines and cork trees, the other inland more arid. Everything proceeds, honoring the magic of the randomness of these events. Until the project is left too free, frightening the client, who feels the need to test this happy alchemy of crossed destinies. He entrusts the two, sculptor and architect, with an opportunity for design and collaboration; a more controlled, more accessible occasion, where it would have been easier to manage any relationship incompatibilities. The OVO project was born (2014) (see Figure 1). In his home, in the Swiss Alps, the client asks Camilo to design a space to house a sculpture by Rui, Semente. The shape of the space resembles an egg, and the chosen place is a rectangular room in the basement of the house. An exercise of consensual enslavement of architecture to sculpture is revealed.

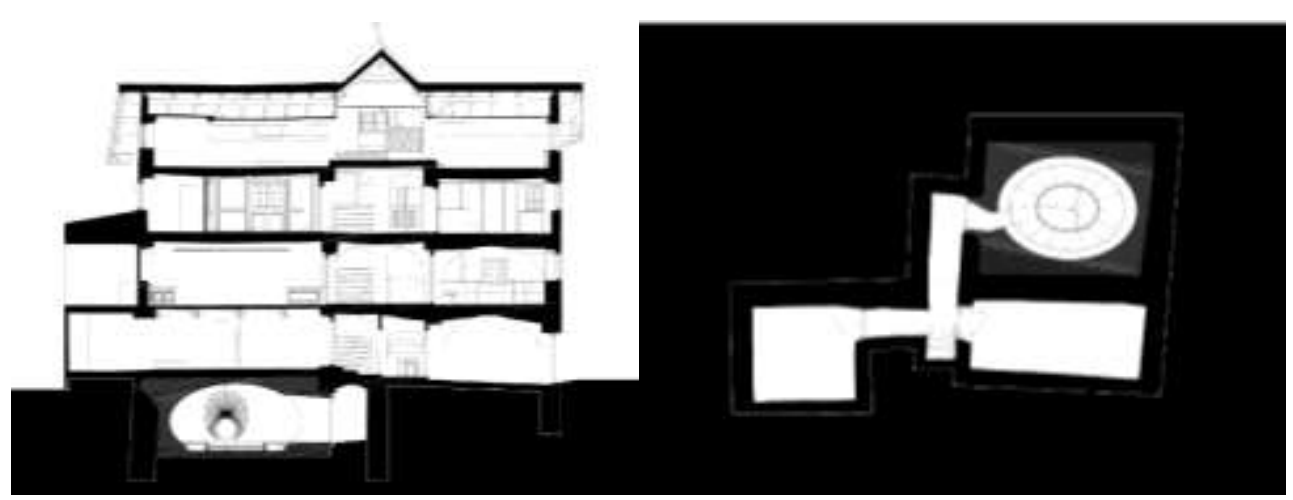

Figure 1. Camilo Rebelo, Ovo's Project

Source: Courtesy of the author.

\section{Ovo: An Exercise in Respect}

It is around this presence and within this idea of origin that the whole story of the relationship between a space and an object of art unfolds. From an interview, we clearly apprehend that the sculptor Rui Chafes recognises a fundamental difference in method between the sculptural process and the architectural process, but that they have always in some way been integrated. It is on the nature of this integration that space is built. Both processes are 'languages of space', and space exists only in the presence of limits, geometry and construction. There is a proximity to architecture, in this specific case, as the artist himself states. His work process is quite close to the architectural process, more than other artists: the iron sculpture requires a project and a technical distance motivated by the very same time of the technological process, which is different for example from what happens with most of the atelier painting. ${ }^{2}$

2. "Personally, my work process is much closer to architecture than what happens with many other artists: iron sculpture requires a project and a technical distance motivated by the time of the 


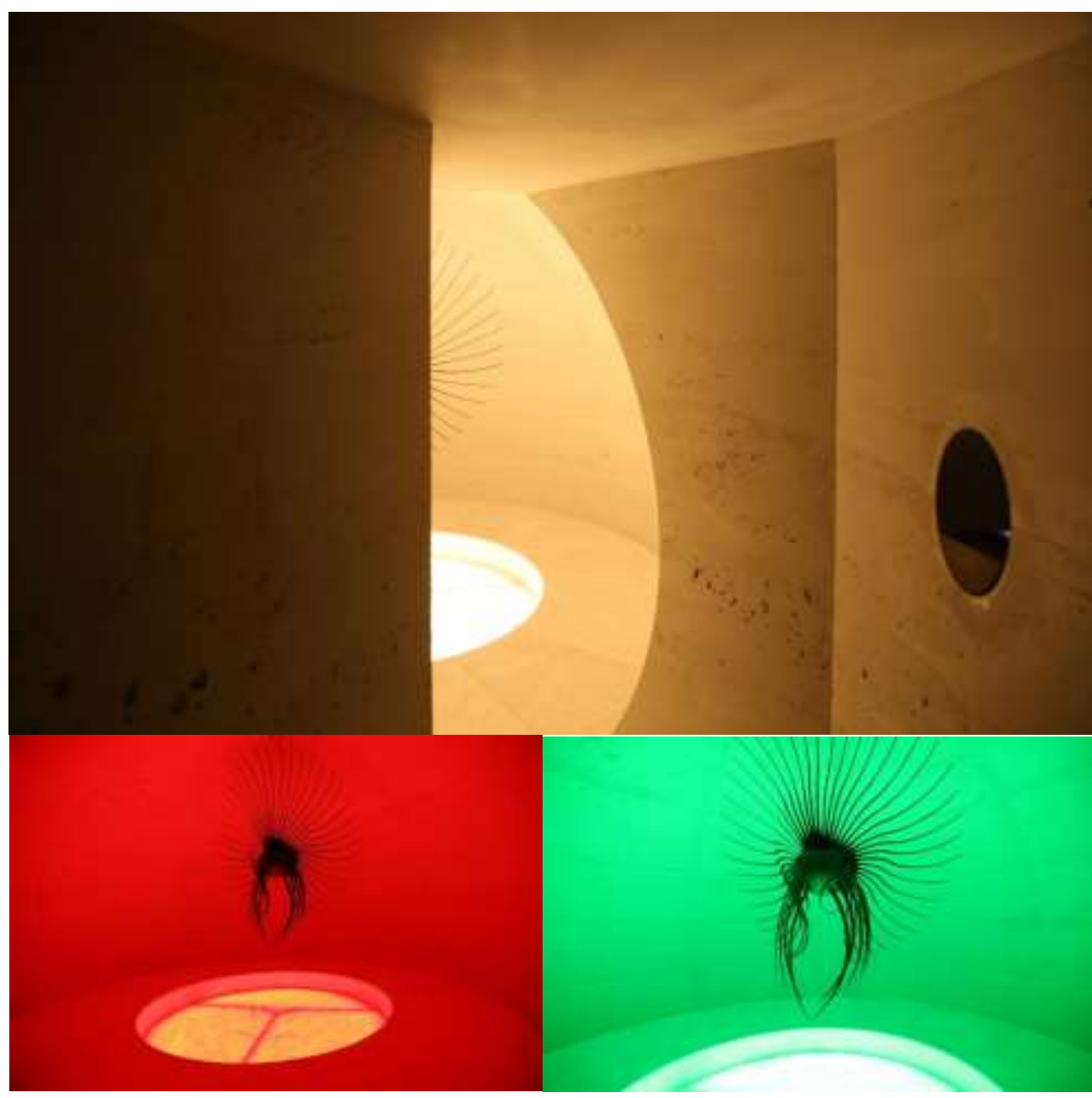

Figure 2. Rui Chafes, Semente

Source: Courtesy of Camilo Rebelo.

The architectural necessity was to create a space to "accommodate" the seed, with a series of restraints required by the sculptor himself: that space had no edges that did not produce shadows or reflections on the sculpture, that it was homogeneous as a surface. The goal was that the dramatic and dark appearance of the materials would not be imposing. The architect welcomes these requests in their absolute legitimacy, shares its rigour and authoritativeness. This project is an exercise in enslaving a work of art. His previous design experience, the museum of Côa (2007-2010), ${ }^{3}$ had already put him to the test regarding the discretion of the architectural space in the face of the need to exhibit works of art and had already educated him about the humility to put at service his compositional activity. Usually, we see common practice concerning art museums to superimpose the architectural space on the exhibited works, which causes a certain difficulty on the part of the artists to feel "welcomed". A mistake that has not been made in the

technological process itself, which is very different, for example, than with most studio painting." R. Maddaluno, From an interview with Rui Chafes. [23 February 2019.]

3. A project with Tiago Pimentel. 
museum of Côa.

The artist's requests set in motion a series of hypotheses also about the materials to be used: the continuity of the required surface could only convey towards choices such as marble, plaster, cement. The first solutions in the form of models presented by the architect were marble cubes, this being a material that would have alluded to the customer's origin (Alentejo) and that would have, due to its uniform materiality, met the sculptor's requests.

The realisation process starts from the construction of a wooden mould in full-scale that would have been the negative of the egg. Built on site, cast in concrete, the wooden egg is disassembled when the drying process is finished. The sculpture offers an image of lightness, of levity, and required around it a unitary space that did not fracture in the construction details, that offered itself continuously and devoid of moments of suspension, of fruition. The lightness of the sculpture needed something that would suggest mass, weight and protection. This ovoid space is completed by a marble floor, a desire not to lose the Alentejo reference. A translucent floor, which allows light to pass, transforming it into a large lamp. A significant effect obtained due to the constructive arrangement of superimposing thin slabs of marble and sheets of tempered glass like a sandwich. The light from below, indeed, does not create shadows.

Another design choice related to light is the introduction of colour, which together with some mandala drawings on the entrance door, transforms this space into a temple that leads to our origins. Each origin is associated with a colour, which has to do with the colour of our energetic aura, and every visitor who enters this space has the possibility of choosing the colour to light it. All this transforms it into a ritual space, but a secular rite that transports us to a journey to the origin, our origin, at the depths of the bottom of our path (see Figure 2).

This space offers something scarce today: a complete silence. And silence is the endpoint in which art and architecture meet, welcoming each other. As Camilo Rebelo states he looks at his space and without Rui's sculpture he hears noise. With Rui's work, he feels that there is silence, alliance, harmony. ${ }^{4}$

Silence irritates, makes presences more alive, forces a sudden awakening of the other senses. It causes angst because sound familiarity is lost, even if, very often, it is noisy.

When the artist first entered this egg, he felt an absolute and almost distressing silence. As Rui Chafes states, there is no doubt that perfection and beauty are present there, harmoniously, but there is an almost 'religious' dimension in space that does not cease to distress him. At the same time, he always has the feeling that he enters that space in order to start a journey and leave for another dimension. It is a starting point; it welcomes and makes one feel uncomfortable. ${ }^{5}$

All the space is designed so that Rui's sculpture can disseminate presence and silence. However, probably the most awaited result from this seed was the success

4. Maddaluno, From an interview with Camilo Rebelo. [1 December 2019].

5. A part of this paragraph was recently in an article by the same author: Maddaluno, "UovoEgg-Oeuf-Ovo: from the origins of the world to a creative objective," in Intelligence, Creativity and Fantasy, 65-70 (ed.) M. Kong, M. R. Monteiro and M. P. Neto. London: London: CRC Press, 2019, 67-68. 
of the collaboration between the protagonists, and the rational verification that the project had gone in the correct direction.

\section{The Verbal Traces of Living}

These projects give the opportunity to reflect on an ancient and complex verb: to live. Although living is a reality, it can only be grasped through a representation, a form because we perceive it only if it is transmuted into figures, models, with the task of describing forms of life. It is not simply a verb but the traces that this verb leaves because it brings into play the physicality of the body with all its needs, but at the same time organizes them according to patterns of habits that belong to the cultural sphere. $^{6}$

The difficulty of relating to the concept of living lies in the fact that it embodies the forms of life and its most elusive characteristics such as heterogeneity, plurality, cyclicality. We are not just talking about physical bodies, although the needs of the latter are contemplated and functionally resolved, but about relationships between bodies, spaces, and voids between spaces, gestures, things, ceremonies and rituals.

The etymology of the verb Abitare (habito-as) underlies the gesture of having, habitually possessing, which opens the meaning of the verb to the idea of property and belonging.

The protagonist of this verb, or rather of its traces, is the body that positions itself, as physicality, in a space that it possesses and dominates, but at the same time to which it belongs. The consciousness of this body lives by the same protagonism, which through the abstraction of thinking detaches itself from what surrounds it. This coexistence between body and consciousness sets in motion a dynamic dialectic between objects and subjects, between interior and exterior, between forms of life and the essence of life. The living space welcomes the body but also welcomes the project of constant flux that one's life implies. Therefore, when we talk about living, we must contemplate another element which is temporality, because living manifests itself in space but takes place over time. The time of living, however, is not resolved in its constant mutation, but in the eternal present of everyday life, in the gestures that are always the same, which are renewed at every sunrise.

In the circularity of the actions, and in the network of movements, a rituality is consummated which is defined by the inhabitant but which in turn defines and identifies him. This is why it is difficult to separate the town from those who live in it, and it is for this reason that it is difficult not to design a home without contemplating who will live there.

The architect's task is hard, as they enter this circular temporality in a desperate attempt to grasp an exceptionality that can give life to the project. The artist's task is even harder, as they have to grasp the temporal abstractions of living, or the whispers of the client's sensibility just waiting to manifest

6. M. Vitta, Dell'abitare. Corpi, spazi, oggetti, immagini (Torino: Giulio Einaudi Editore, 2008), 4. 
themselves. When asked how to enter a private house with one's art, Rui Chafes replies that one does not enter, one is already there, the works are already present, in the client's head, in the maze of the house. The artist enters only to confirm that those are the right sculptures just waiting to be born. He continues by stating that the artist only has to find out where the eggs are waiting to hatch. ${ }^{7}$

This project is designed to lose the habits that the client has developed in his life and force him to reconnect with his nature and the nature of the spaces around. Hence the fragmentation of spaces, the idea of a shape almost resulting from an explosion, where each fragment has its place far from the others. The house away from the parking lot, the pool away from the house, the outbuilding away from everything. And when everything is far away, the only hypothesis is to reduce the distances, how? By walking.

Paraphrasing a quotation from Zevi, architecture is a bipolar structure, with an "artistic" pole, defined by the text created by the author (in this case the architect) and an "aesthetic" pole, corresponding to the concretization implemented by the reader (in this case the client, or those who live in the house). This polarity produces a consequence: the final work never completely coincides neither with the text (in this case the designer who performs the role of author function) nor with its concretization (the inhabitant as protagonist). The architect finds himself in the difficult role of the curious spectator, who welcomes and respects the present and future freedoms of the inhabitant. ${ }^{8}$

The architect's difficult task is having to relate to the identity of the client. In addition, the identity of a person has a part destined to remain unchanging over time: what is called the idem identity. And this is the easiest to identify and welcome by the designer. But the identity is also composed of another identity, which takes into account the changes in that it considers the person as a character in a story that must be told. This is the narrative identity or ipse identity. ${ }^{9}$ In the history of each individual, there is their identity, which is the result of a narrative. This narrative cannot simply be an autobiography, because it would represent the way in which each of us sees ourselves. But it must be resolved in a biography, that is, in the writing of how others see and talk about us.

If we wanted to extend this reflection on the duplicity of the roles of landscape, paraphrasing Turri, it is of no less importance than the research on how the man actor undergoes the scenario and intones his performance in the landscape is about the way in which he sets up the landscape to act or represent his own stories. ${ }^{10}$

\section{Chafes, Promise, 2020.}

8. Vitta, Dell'abitare. Corpi, spazi, oggetti, immagini, 2008, 117.

9. On the theme of identity and recognition Paul Ricoeur has dedicated profound reflections. See Soi-même comme un autre, (Self as another) 1990, (trad. It. Sé come un altro), Jaka Nook, Milano 1993); Parcours de la reconnaissance, (Path of Recognition) 2004 (trad. It. Percorsi del riconoscimento, Raffaello Cortina, Bompiani, Milano 2005).

10. E. Turri, Il Paesaggio come teatro. Dal territorio vissuto al territorio rappresentato (Venezia: Marsilio, 1998), 36. 


\section{Living between Spirit and Nature}

"Architecture, like the fire of Prometheus, separates culture from nature, the discrete from the continuous, and unites time and space while extracting the defined object from the indistinct and undifferentiated; it is universal particularity, separate entity and measured limit, and it is sacred as such for this: in the most ancient texts of humanity it is already written that existence is taken from nonexistence through measurement." 11

The final project of the house is a set of constructive events: the main house, the farmer's house, an open water cistern / swimming pool, a garage. The choice to start from the suggestions of the nature of the place goes against a common design practice of imposing presences through formal language. The gesture of "letting emerge" has replaced the gesture, dear to the modern movement, of "placing" objects formally pre-established or partially adaptable to the place (see Figure 3).
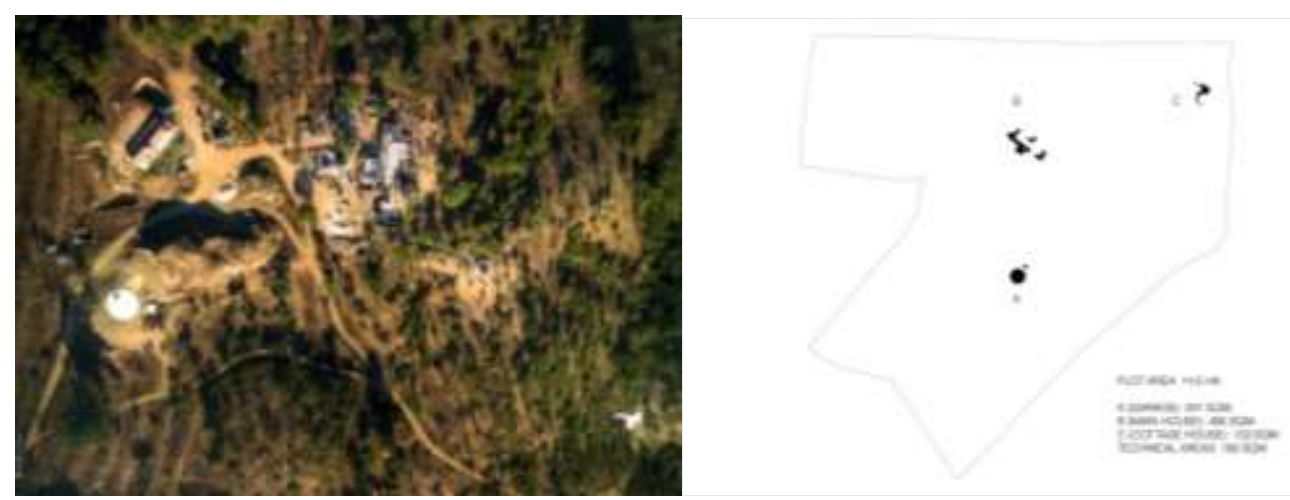

Figure 3. Planimetric View of the Project Promise

Source: Courtesy of Camilo Rebelo.

As Bonesio states, the logic of places is, contrary to what a modernist homologating abstract vision has imposed on us, "a logic of singular, concrete, differential, territorializing plurality."

Although the conviction that intervening is always a constructive gesture that implies an unavoidable modification of the space is maintained in the project, it is clear that the approach is one of dialogue with nature. In this design work mode, the tools of the architectural language go beyond the conventions and construction customs, leaving open new possibilities: a tree, or a typographic dimension, a wall, a window, have the same potential to define and limit the space.

Paraphrasing Simmel in an essay on the aesthetics of landscape, this journey towards nature leads us to perceive, each with different degrees of attention, water and trees, meadows and fields, hills and houses, and the myriads of transformations of light and clouds. But this observation made of single details does not convince

11. G. Bilancioni, "Prefazione. I cardini celesti dell'architettura sacra," in Architettura, Tempo, Eternitá. Il simbolismo degli astri e del tempo nell'architettura della tradizione, XI-XXV. (ed.) A. Snodgrass and G. Bilancioni. Milano: Bruno Mondadori, 2008, XII.

12. L. Bonesio, "Il paesaggio come luogo dell'abitare," in Estetica e paesaggio, 239-268 (ed.) P. D’Angelo. Bologna: Il Mulino, 2009, 258. 
our mind that it needs a totality that he defines as landscape, but which in this case we could call a project an idea, an overview, or intuition. ${ }^{13}$

As Dewey warns, the enemies of aesthetics are the conventional experiences of the world, those that oblige us to monotony, to experience the rudimentary. And it offers us as a solution, the great power of imagination, which represents an important resource, together with perception, to accept with conscience the aesthetic challenge that nature launches, and to create new points of view of the world. Points of view that the architectural project contemplates at the exact moment in which the creative process begins. ${ }^{14}$

We should try to fully understand the importance of this creative moment, probably helping us with the definition of the fields of our semantic discourse. First, when we talk about nature, we mean the infinite connection of things, becoming through being born and destroyed, the unitary flow of the future, in spatial and temporal continuity. Nature, as Simmel states, is not composed of parts, on the contrary it is THE UNITY OF A TOTALITY and in the moment in which something is separated from it, it can no longer be called nature. Nature is unity without boundaries. When we refer to nature as an element of reality, we are probably talking about an internal quality of it. Instead, to be more specific, we should talk about landscape and with it the project, where delimiting is absolutely fundamental for its existence in a temporal horizon. The parts of a landscape may have the value of nature but require an individual act with respect to the universal and the indissoluble unity of nature. ${ }^{15}$

What man does, when he produces phenomena (among which we can include built projects) in the landscape category is a real spiritual act composed of: a complete vision felt as self-sufficient, but connected to something infinitely more extensive, where the limits of feelings are not perceived.

The work of man exists as an objective structure, yet intimately connected with the vitality of his being, of his soul. Nature, which in its being and in its deep sense, ignores individuality, is transformed into the individuality of the landscape by the gaze of man, who divides and configures what it has divided into distinct forms of unity. ${ }^{16}$

What the architect does on this place starts from a simple gesture: to feel the place in its dual meaning, as a landscape and as part of a natural totality. Feeling is fuelled by a relationship that is established through walking, walking, stopping and observing.

Eugenio Turri talks to us about the importance of walking by observing, walking in the perception of reality. He considers it a pause from the action, which allows us to immerse ourselves in the landscape, to breathe its breath. Walking allows you to relate to the landscape in a twofold way: as actors (insiders when

13. G. Simmel, "Filosofia del paesaggio," in Estetica del paesaggi, 39-52 (ed.) P. D’Angelo. Bologna: Il Mulino, 2009, 41.

14. J. Dewey, Arts as experience (New York: Perigree Books, 1980), 40.

15. Simmel, "Filosofia del paesaggio," 2009, 42.

16. Ibid, 43. 
you are inside), but also as outsiders, that is, as spectators, because in walking we do nothing but look, not being finally engaged in anything. ${ }^{17}$

This is what somehow, we are called to do when we visit the place where Promise was born. You start walking, for no particular reason. And so the constructive realities present there manifest themselves, as if to force us to stop to observe, to then start walking again, to observe and then again to stop.

Sensory perception must lead us to the rules of artifice, or project. And the big question of a creative project that is imposed not without a certain violence is: How can I experience the artifice without necessarily having to forget the nature of elements? These elements of Nature obliges us to an experience in which the body must necessarily be solicited. These elements, the wind, the sun, provoke physical reactions: cold, heat, comfort, discouragement. For a highly urban person, such as the client, who spent most of his life between London and Paris, the experience of nature meant in terms of the project, obliging him to go on foot.

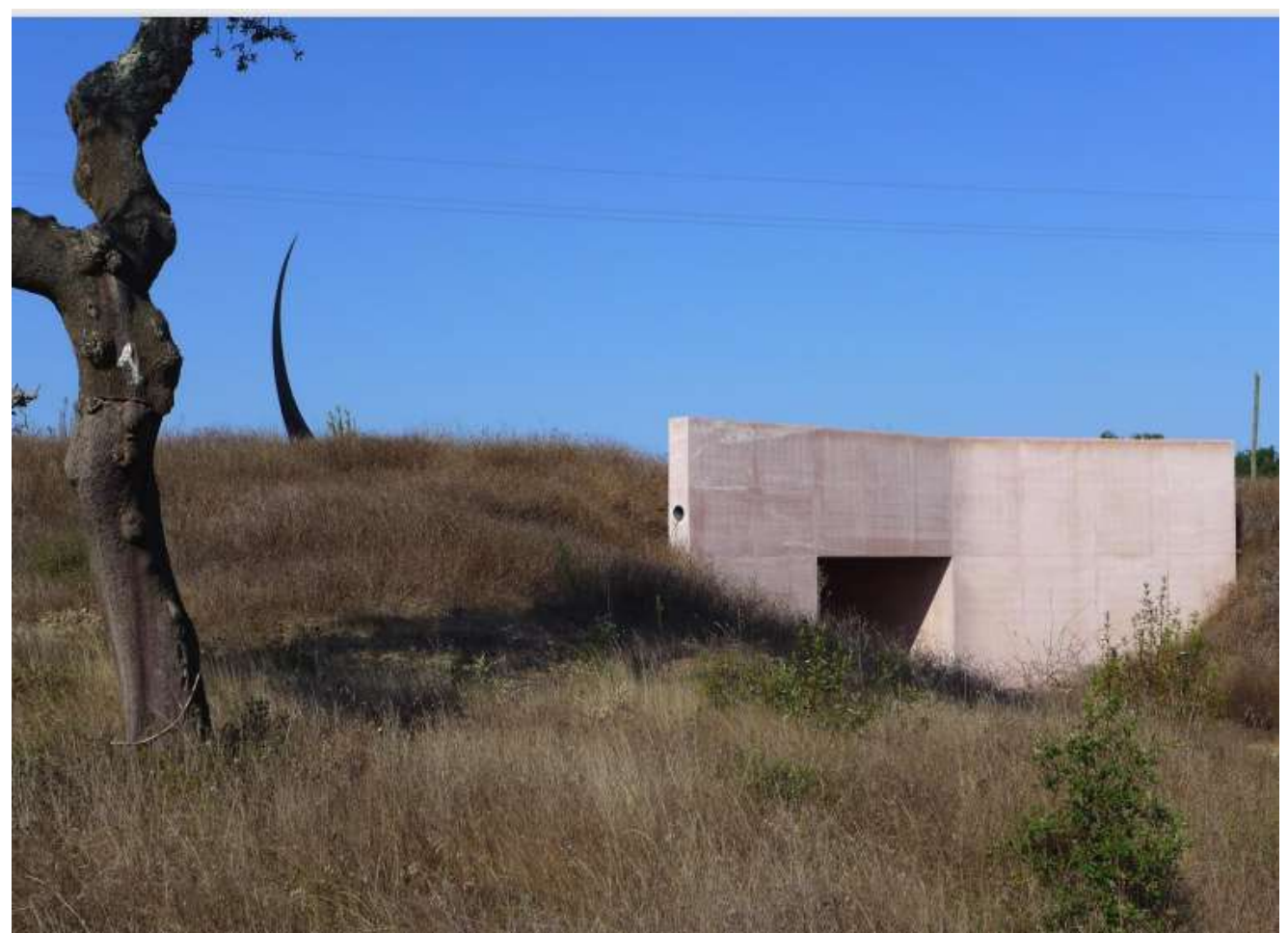

Figure 4. Access to the Garage and Sculpture by Rui Chafes Source: Courtesy of Camilo Rebelo.

The housing complex has become an opportunity to experience through spatial fragments, connected to each other by nature. Between the point where you arrive by car (the garage) and the main house, you can walk three hundred meters. The route tests the body: the ground is not flat, you can feel the wind, feel the heat, possibly catching the rain, seeing the landscape, listening to the voices of nature. 186.

17. Turri, Il Paesaggio come teatro. Dal territorio vissuto al territorio rappresentato, 1998, 
And as you walk, the words of Rui Chafes come to mind who says you have to allow yourself the luxury of time to be able to listen to the voices in the wind.

The composition welcoming the different natures, both of the protagonists, and methodological, resembles a jazz musical ensemble, where everyone contributes with their individuality, and respecting the rhythm of the place, to create an episode of constructive life. It is no coincidence that Promise is the name of a musical album by Omar Sousa, a friend of the client and who has sometimes accompanied the creative meetings of the project.

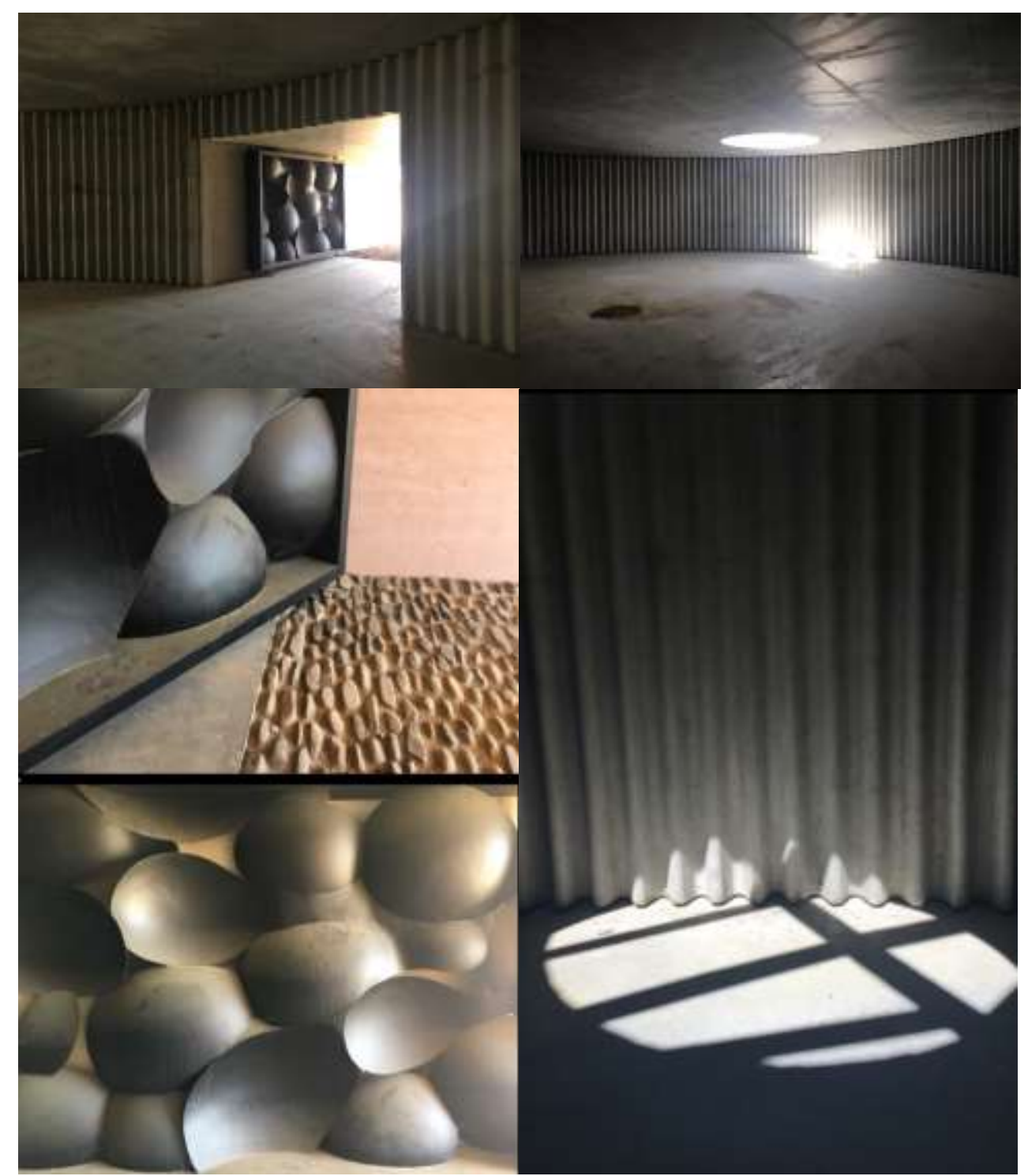

Figure 5. Details of the Interior of the Garage and the Iron Door of Rui Chafes Source: photographs by the author.

This contact with nature implies abandoning all that is not our body, all that artificially complements our identity. This is what happens for example in the process of identification with objects. Those three hundred meters in the project divide the two moments where the artifice enters into a relationship with our 
identity: the first through the object (garage-car), the second through living (home). In the middle, we, the body, who through the experience of nature, experience our essence. Sculpture and architecture meet in this first place of the project: the garage. A circular space, which refers to timeless models, such as the Pantheon. A place where time is measured through light. A place where an iron nail reminds us of the hand of a clock and the divine circularity of the passing of the hours. In this circular space, which is accessed through a heavy and light portal at the same time, where the artist's hand has been able to bend the rigidity of the iron in favor of lightness and transparency, we begin our transformation towards ourselves. Everything is artifice, even the walls: a continuous corrugated wall reminiscent of a curtain that separates from the world. Its archetype of reference seems to be the tholos of the prehistoric cave: a space like that of the Gurfa cave in Sicily, or the sacred building of Peter Zumthor, a space enlivened by the changing light that enters the oculus (as later seen in the Pantheon) and from the dust atmosphere that that light projects on the rough surfaces of the rock (see Figures 4-5).

The main house is positioned in such a way that noises from the cars are not heard, even the windows give their backs to this reality of the car. As Carlos Martí Aris says, "the noise of the world is oppressive and deafening." The whole project is designed to have an experience of silence, just like the OVO project. "The only one capable of opposing noise is silence. Silence opens a deep breach in the convulsive and feverish scenario of our daily life. It generates a cavity and an empty space, which distracts us from the vortex of current affairs. However, paradoxically, this invocation to silence is only a demand for the word. In fact, silence is not opposed to the word, of which it is a faithful ally, but to the noise, which is its archenemy ${ }^{18}$ (see Figure 6).

Promise has the ability to generate silence, and when a project has this property, as Martí Aris says, it allows you to look at reality with an abstract look, thanks to which you can enter the dimension of contemplation, and not only of function .And it is in this dimension that the work of Rui Chafes works, allowing housing to transcend. This silence that is heard here does not cancel language but transcends it. ${ }^{19}$

18. C. Martí Arís, Silenzi eloquenti (ed.) S. Perini. (Milano: Christian Marinotti Edizioni, 2007), 120-121.

19. Ibid, 121. 


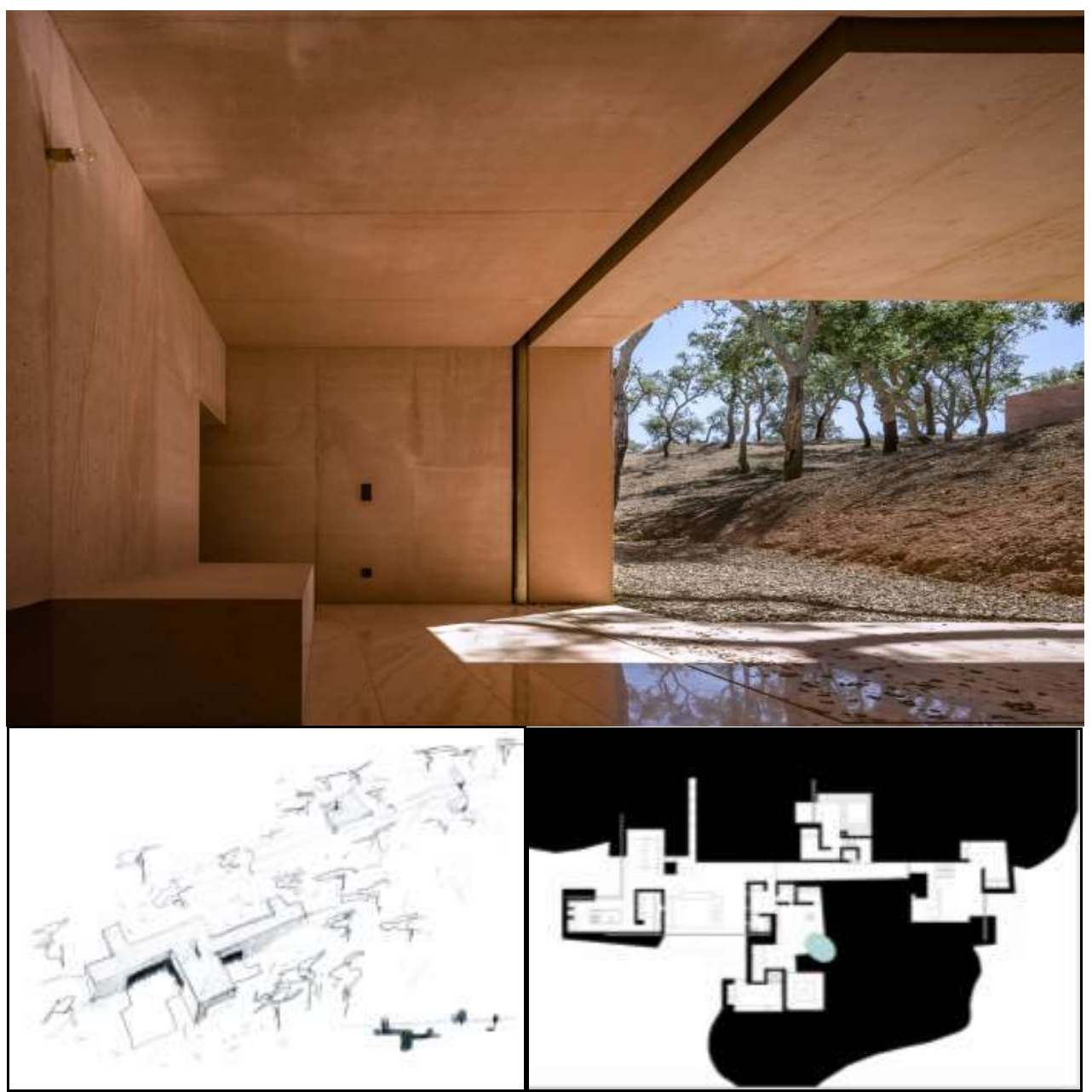

Figure 6. Photos and Drawings of the Main House

Source: Courtesy of Camilo Rebelo.

\section{A Built Void}

"A house is a space that does not exist, which must be built daily, without ever stopping, infinitely. And that it will never be over." Rui Chafes ${ }^{20}$

20. Chafes, Promise, 2020. 


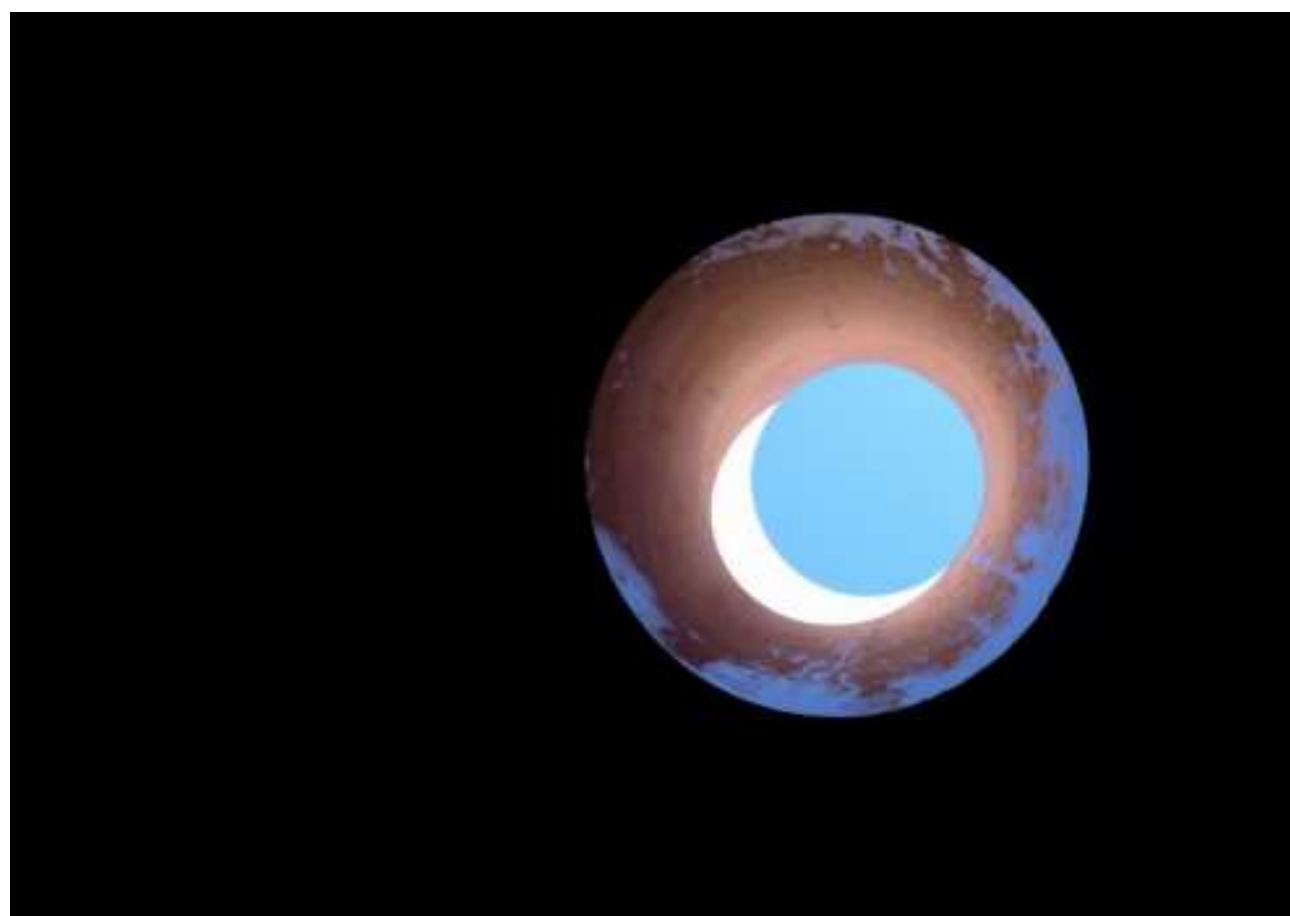

Figure 7. One of the Windows of the Main House

Source: Courtesy of Camilo Rebelo.

This transcendence from language takes him even further, when he affirms that art is not personal or individual expression. Art is an expression of emptiness and of the ancient, primordial ideas of humanity that have been transmitted, learned and reworked over time. It is for this reason that we are able to love a Greek, Egyptian, Etruscan sculpture without necessarily loving its creator who we do not know. The artist's journey is to transport the flame, passing it on to others through new images and objects. ${ }^{21}$

Rui Chafes in his art always tries to preserve a space for silence, for the incomprehensible, and even a space for mystery. He is only interested in art as a producer of irrational and acute energy because art is anything but communication. The Promise House recalled the works of Oteiza, in its process of emptying and unemployment of matter. The empty space that is obtained from this process is a static, calming and contemplative space, a refuge.

"If the current sculpture - explains the author - tends to imagine the movement and produce it, merging with nature or with man himself, I instead look for the statue for an empty solitude, an open spatial silence, that man can occupy spiritually "(...). "I need - he adds - to break the connection of time with space, that is to transform the space of external reality into a space of internal reality, into an immobile spatiality, which means capable of living outside of time." 22

21. Chafes, Sob a pele (ed.) S. A. Matos (Lisboa: Documenta. Cadernos do atelier-museu Júlio Pomar, 2016), 62-63.

22. J. Oteiza, "Hacia un arte receptivo. Towards a receptive art," in Espacialato. Oteiza. (Pamplona: Cultural Rioja, 2000), 123. 
The author's goal is therefore purely spiritual and is manifested not in the movement but in the stillness conceived as a final silence -totem. ${ }^{23}$

While the sculptural/architectural mass tapers away, the internal void takes shape and takes over the space. This evacuated space becomes available, but traces of the sub-action process still remain available. This manipulation of matter, through the necessity of technique, brings sculpture and architecture closer together. As Rui Chafes says, "mediation" introduced by technique and also by manual work brings sculpture closer to architecture. But he also goes on to say that there is a fundamental difference that unequivocally delimits its areas. Architecture exists because it provides answers to a series of practical problems, which relate to space (see Figure 7).

On the contrary, the artist does not look for solutions to practical problems, instead he looks for the best way to ask uncomfortable questions, to create problems, to disturb the world. Maybe that's why, says Rui Chafes, art is absolutely useless, because it has no function. In summary: In architecture "for every problem there is a solution". In art "for every solution there is a problem." ${ }^{24}$

It is work on the void that Rui Chafes has always done. It guards the void with its iron armour, it protects it because it generates mystery. In reality, he says, art is a construction and will always be a language of emptiness. The void can be at the same time, the most sterile hell, the nest of the impossible, and the only possible field where we can deposit a shape, a color, a word, a sound, little more (...) the void, nothing, are the closest attitude to God. ${ }^{25}$

23. M. Pelay Orozco, Oteiza, su vida, su obra, su pensamento, su palabra (Bilbao: La Gran Enciclopedia Vasca, 1978), 194.

24. Chafes, Sob a pele, 2016, 120-121. Camilo and I found ourselves at this point of enormous respect for each other, in this wait for the decisions of the other to move forward. Camilo works with a team that develops ideas and models and I am unable to work with models and plan sculptures on models. I can only react to real space, I have to live a space, be physically inside it, in its presence, to be able to react and think about some sculptures. This is a point of procedural disagreement with Camilo or any architect (Chafes, Promise, 2020).

25. Chafes, Sob a pele, 2016, 56. 


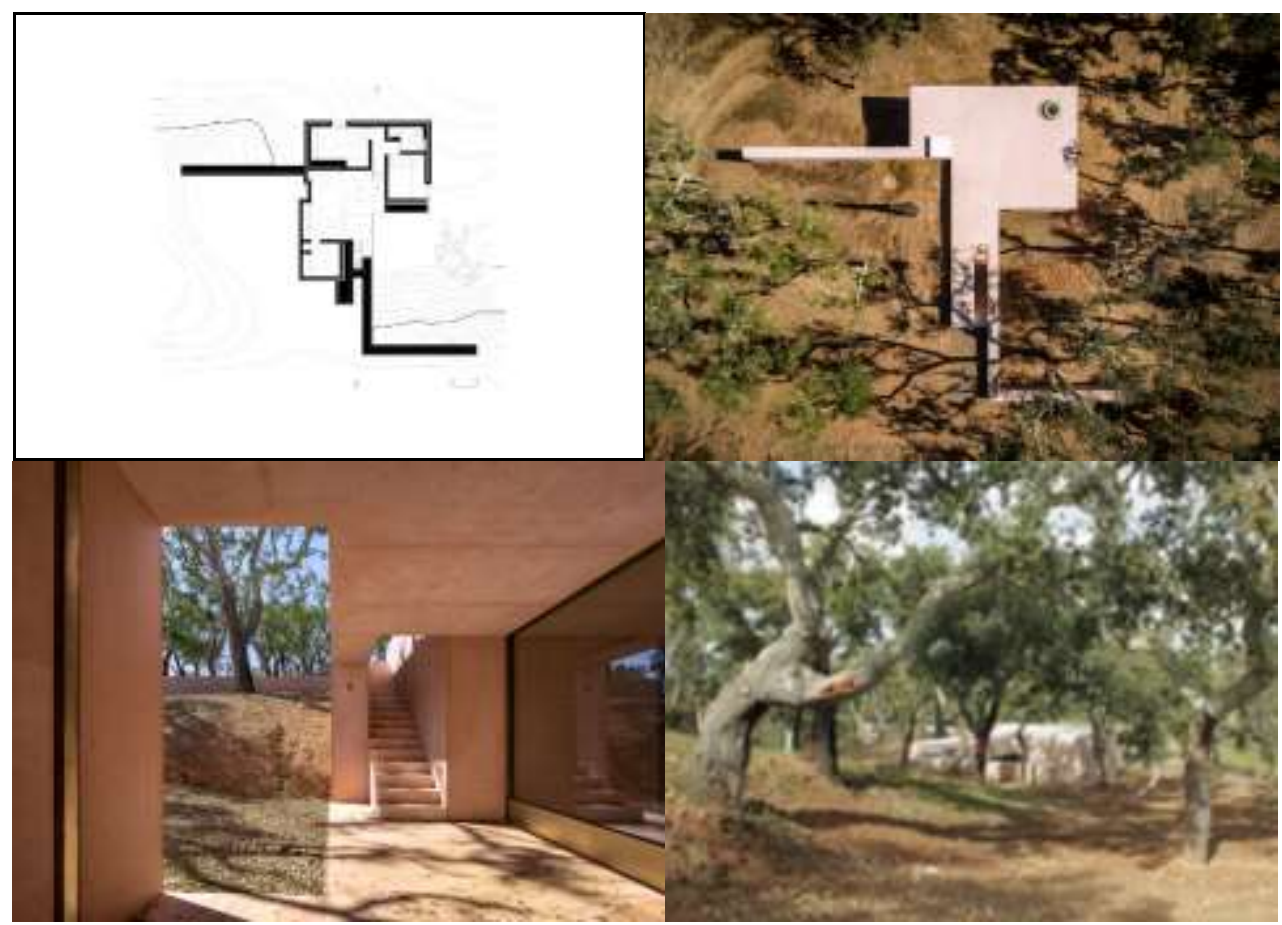

Figure 8. Cottage House

Source: Courtesy of Camilo Rebelo.

\section{A Non Conclusion}

In Promise The matter, transformed into constructive materials, continues to perceive itself in all its essence. The walls are reminiscent of the earth, even if they are not earthly. The whole house, in its constructive episodes, is the result of sophisticated and expensive excavation and construction techniques. Promise is a constructive action not yet completed; therefore, the totality and completeness of the final result is not perceived.

What clearly emerges, however, is that we are in the presence of an architecture that has the ability to test us. It forces us to reconsider the automatisms and images of the house we are used to. It requires us to leave the numerous cultural, social and well-being restrictions that our time has become accustomed to. And free us from the layers, we and our body can walk from one place to another, thinking in the end that architecture is a conquest (see Figure 8).

Promise, as Rui Chafes tells us, is a large space, the result of a dream of a man who does not consider it just his dream, but a gift to be left to those who recognize the beauty of forms and non-forms. Each space is the gesture of trust in the immateriality and continuity of the dream: this is why it is called Promise. There will be no end word, because there has never been a real beginning. ${ }^{26}$

26. Chafes, Promise, 2020. "Promise is a large and wide space, made for the dream of one man that does not consider it his own dream, nor his own property, not even his own decision. "Promise" started with a dream, the dream of bringing a space to the world that belongs to the world, not to a single person. In that matter, Olivier's point of view was always very clear and lucid, 


\section{Bibliography}

Bilancioni, G. "Prefazione. I cardini celesti dell'architettura sacra." [Preface. The heavenly hinges of sacred architecture.] In Architettura, Tempo, Eternitá. Il simbolismo degli astri e del tempo nell' architettura della tradizione, XI-XXV. Edited by A. Snodgrass and G. Bilancioni. Milano: Bruno Mondadori, 2008.

Bonesio, L. "Il paesaggio come luogo dell'abitare." [Landscape as a place of living.] In Estetica e paesaggio, 239-268. Edited by P. D’Angelo. Bologna: Il Mulino, 2009.

Chafes, R. Sob a pele. [Under the skin.] Edited by S. A. Matos. Lisboa: Documenta. Cadernos do atelier-museu Júlio Pomar, 2016. . Promise. Interview edited by R. Maddaluno. Lisboa. [20 July 2020.]

Dewey, J. Arts as experience. New York: Perigree Books, 1980.

Maddaluno, R. "Uovo-Egg-Oeuf-Ovo: from the origins of the world to a creative objective." In Intelligence, Creativity and Fantasy, 65-70. Edited by M. Kong, M. R. Monteiro and M. P. Neto. London: London: CRC Press, 2019.

Martí Arís, C. Silenzi eloquenti. [Eloquent silences.] Edited by S. Perini. Milano: Crhristian Marinotti Edizioni, 2007.

Oteiza, J. "Hacia un arte receptivo. Towards a receptive art." In Espacialato. Oteiza. Pamplona: Cultural Rioja, 2000.

Pelay Orozco, M. Oteiza, su vida, su obra, su pensamento, su palabra. [Oteiza, his life, his work, his thought, his word.] Bilbao: La Gran Enciclopedia Vasca, 1978.

Simmel, G. "Filosofia del paesaggio." [Philosophy of landscape.] In Estetica del paesaggi, 39-52. Edited by P. D'Angelo. Bologna: Il Mulino, 2009.

Turri, E. Il Paesaggio come teatro. Dal territorio vissuto al territorio rappresentato. [Landscape as theatre. From the lived territory to the represented territory.] Venezia: Marsilio, 1998.

Vitta, M. Dell'abitare. Corpi, spazi, oggetti, immagini. [About living. Bodies, spaces, objects, images.] Torino: Giulio Einaudi Editore, 2008.

without any kind of craving or material attachment: he always wanted "Promise" to be a gift to the world, to the others, to the ones who recognise the beauty of Form and the beauty of Non-Form. We can see it as a high form of generosity as well as a high form of future vision and absolute trust. It is a gift to the ones who can pass through the world without wanting to leave traces, like birds in the sky. We are building "Promise" at the same time as we are dreaming "Promise", as a house without beginning neither an end. It will not be a "work in progress" but much more an unfinished state of mind, where each wall, each spot of light, each room is part of an immaterial and continuous trust in Beauty and Dream. That is why it is called "Promise". No one will ever finish it, because it has never begun. We all hope that this unnameable project will offer people the desire of freedom and conscience of the greatness and ephemere beauty of our lives. Without wanting to own what it is impossible to own. It is the shadow of a brief permanence, always moving in time, back and forward." from a text written in English sent by mail by Rui Chafes to the author [20 July 2020]. 